\title{
Three essays on international trade: Strategic trade policies, intra- industry trade, and income convergence
}

Aziz Ibrahim Saglam

West Virginia University

Follow this and additional works at: https://researchrepository.wvu.edu/etd

\section{Recommended Citation}

Saglam, Aziz Ibrahim, "Three essays on international trade: Strategic trade policies, intra-industry trade, and income convergence" (2006). Graduate Theses, Dissertations, and Problem Reports. 4264.

https://researchrepository.wvu.edu/etd/4264

This Dissertation is protected by copyright and/or related rights. It has been brought to you by the The Research Repository @ WVU with permission from the rights-holder(s). You are free to use this Dissertation in any way that is permitted by the copyright and related rights legislation that applies to your use. For other uses you must obtain permission from the rights-holder(s) directly, unless additional rights are indicated by a Creative Commons license in the record and/ or on the work itself. This Dissertation has been accepted for inclusion in WVU Graduate Theses, Dissertations, and Problem Reports collection by an authorized administrator of The Research Repository @ WVU.

For more information, please contact researchrepository@mail.wvu.edu. 


\title{
Three Essays on International Trade: \\ Strategic Trade Policies, Intra-Industry Trade, and Income Convergence
}

\author{
Aziz İbrahim Sağlam \\ Dissertation submitted to the \\ College of Business and Economics \\ at West Virginia University \\ in partial fulfillment of the requirements \\ for the degree of \\ Doctor of Philosophy \\ in \\ Economics \\ Subhayu Bandyopadhyay, Ph.D., Chair \\ Ashok B. Abbott, Ph.D. \\ Arabinda Basistha, Ph.D. \\ Ming-jeng Hwang, Ph.D. \\ Santiago M. Pinto, Ph.D. \\ Division of Economics and Finance \\ Morgantown, West Virginia \\ 2006
}

Keywords: Strategic Trade Policies, Export Subsidies, Countervailing Tariffs, Managerial Incentives, Intra-Industry trade, Income Convergence. 


\title{
Abstract \\ Three Essays on International Trade: \\ Strategic Trade Policies, Intra-Industry Trade, and \\ Income Convergence
}

\begin{abstract}
Aziz İbrahim Sağlam
This dissertation illustrates the effects of managerial delegation on strategic trade policies and the relationship between intra-industry trade and income convergence. In the first essay strategic trade policy under duopoly is investigated in a multistage game model with endogenous timing of trade policy. The analysis also includes the separation of ownership and management for each firm. The study is integrated in a single analytical framework. The results show that in the subgame perfect equilibrium of the trade policy game, the home government commits not to use countervailing duties: the home government sets its tariff and production subsidy at stage one and the foreign government sets its export subsidy at stage two. As a result both countries are better off when the home government is the Stackelberg leader. The second paper analyzes the relationship between international trade and income convergence among countries by focusing on groups of countries comprising major trade partners. For each country, primary intra-industry trade partners are determined and trade groups are created. The behavior of income differentials within these groups is examined. The majority of these intra-industry trade-based groups exhibit significant income convergence. The third paper provides recent evidence on determinants of the bilateral intra-industry trade in a multi-country \& multiindustry framework. The empirical results show that the extent of intra-industry trade is positively correlated with average GNP, average GNP/capita, and the existence of a common border; and it is negatively correlated with difference in GNP, difference in GNP/capita, and distance. All the variables are highly significant statistically. The EU and NAFTA dummy variables have the expected positive sign and are highly significant statistically. The regression coefficients of the language dummy variables have a positive sign, but their level of statistical significance varies.
\end{abstract}


To my parents,

Cevat Sağlam and Solmaz Sağlam 


\section{Acknowledgements}

Foremost, I would like to thank Allah for His bounties and blessing. He has blessed me with loving parents, brothers, sisters, teachers, and friends. I also thank Him for the guidance and ability He has provided me to finish this research. Surely, without His mercy and blessing this work would not have been possible.

I would like to thank my advisor, Prof. Subhayu Bandyopadhyay for his invaluable support throughout this study, for his inspiration and guidance. I would also like to thank the members of my dissertation committee for all their comments and input on this work: Prof. Ashok B. Abbott, Prof. Arabinda Basistha, Prof. Ming-jeng Hwang, and Prof. Santiago M. Pinto.

I am also grateful to Prof. Ronald Balvers, Prof. Brian Cushing, and Prof. William Trumbull for their belief in me.

I am forever indebted to my parents, Cevat and Solmaz Sağlam, who have taught me the value of knowledge. Their love and support is always with me. Special thanks go to my brother İsmail for everything he did for me while I was on this Ph.D. journey. 


\section{Table of Contents}

Table of Contents $\quad$ V

List of Tables viii

Chapter 1. General Overview of the Dissertation 1

Chapter 2. Export Subsidies, Countervailing Tariffs and Managerial

Incentives in Strategic Trade Policy Games 10

1. Introduction 10

2. Literature Review 16

2.1. Imperfect Competition and International Trade:

Emergence of the Strategic Trade Policies 16

2.2. The Pioneering Brander and Spencer (1985) Model 17

2.3. Countervailing Tariffs: The model of Collie (1994) 19

2.4. The Strategic Choice of Managerial Incentives 20

3. The Model 22

3.1. Stage 3: Managers choose their firms' outputs 25

3.2. Stage 2: Owners choose their managers' incentives 26

3.3. Stage 1: Governments choose their trade policies 30

3.3.1. Simultaneous-Move Trade Policy Game 31

3.3.2. Stackelberg Game when the Foreign Government

is the First Mover 33

3.3.3. Stackelberg Game when the Home Government is the First Mover 35

3.3.4. The Timing of Trade Policy Decisions 38

4. Conclusions 43

5. References $\quad 45$

$\begin{array}{ll}\text { Appendix } & 48\end{array}$ 
Chapter 3. Income Convergence \& Intra-Industry Trade 56

1. Introduction 56

2. Literature Review $\quad 60$

2.1. Income Convergence $\quad 60$

2.2. Intra-Industry Trade 62

2.3. Trade and Income Convergence 64

3. Data and Methodology 67

3.1. Data $\quad 67$

3.2. Grubel-Lloyd Index and Aggregation Problem 68

3.3. Creation of the Trade Groups $\quad 69$

4. The Model 70

4.1. Income Convergence Model $\quad 70$

4.2. Random Country Groupings 71

4.3. Exclusion of Partners 72

$\begin{array}{ll}\text { 4.4. Language and Proximity } & 73\end{array}$

$\begin{array}{ll}\text { 5. Conclusions } & 74\end{array}$

6. References $\quad 75$

$\begin{array}{ll}\text { Appendix } & 82\end{array}$

Chapter 4. Determinants of Intra-Industry Trade in a Multi-Country \& Multi-Industry Framework: An Empirical Analysis 91

1. Introduction $\quad 91$

2. Literature Review 95

3. Data and Methodology 99

3.1. Data 99

3.2. Grubel-Lloyd Index and Aggregation Problem 100

3.3. Estimation Techniques 101

$\begin{array}{ll}\text { 3.4. Methodology } & 101\end{array}$

4. The Model 104 
$\begin{array}{ll}\text { 4.1. The Theory } & 104\end{array}$

4.1.1. Closed Economy 104

4.1.2. Integrated Economy 106

4.1.3. Trade Volume and Trade Pattern 108

4.2. Results of the Empirical Analysis 110

5. Conclusions 114

$\begin{array}{ll}\text { 6. References } & 115\end{array}$

$\begin{array}{lr}\text { Chapter 5. Summary and Conclusions } & 119\end{array}$ 


\section{List of Tables}

\section{Chapter 2}

Table 1. Comparison of Results in the Simultaneous-Move Trade Policy Game

Table 2. Comparison of Results in the Stackelberg Game when the Foreign

Government is the First Mover

Table 3. Comparison of Results in the Stackelberg Game when the Home Government is the First Mover 50

Table 4. Payoff Matrix for Trade Policy Game

\section{Chapter 3}

Table 1. List of Countries in Trade Groups 82

Table 2. Trade Groups' Convergence Coefficients (IIT-Based Groups) 83

Table 3. Trade Groups' Convergence Coefficients (Trade-Based Groups) 84

Table 4. Distribution of Convergence Coefficients 85

Table 5. Comparison of the Results when Groups are Formed Randomly 86

Table 6. Comparison of the Results when USA is Excluded 87

Table 7. Comparison of the Results when Ireland is Excluded 88

Table 8. List of Countries in Language and Geographical Groups 89

Table 9. Convergence Coefficients of Groups Based on Language and Proximity 90

\section{Chapter 3}

Table 1. Estimation of Intra-Industry Trade in a Multi-Country and Multi-Industry Framework

Table 2. Comparison of the Coefficients of Determination in Different Models 


\section{Chapter 1. General Overview of the Dissertation}

The assumptions of constant returns to scale and perfect competition are often violated in the real world. Traditional trade theory based on perfect competition does not effectively explain phenomena such as intra-industry trade and the high volume of trade between similar countries. Moreover, such models failed to successfully integrate some important policy related considerations, such as increasing returns to scale, learning-by-doing, $R \& D$, and inter-firm strategic rivalries. Effective analysis of these topics requires imperfect competition, which together with increasing returns to scale is one of the main characteristics of many of today's industries, especially of those in the industrialized countries. As new theories of imperfectly competitive markets have developed, game-theoretic approach of strategic trade policy began to emerge in the early 1980 's.

As a strategic trade policy instrument, an export subsidy used by the foreign government could be "countervailed" by a domestic import tariff. The interesting point about these countervailing effects is that they do not eliminate incentives to use active strategic trade policy, and the policy equilibrium normally implies positive subsidies and tariffs. Collie (1994) examines a country's optimal response to foreign export subsides. In his model, the home government uses an import tariff to extract rents from the foreign firm and a production subsidy to correct the domestic distortion due to imperfect competition. The foreign government uses an export subsidy to shift profits from the home firm to the foreign firm. He shows that the unique equilibrium sequence of moves of the governments is that the home government announces its trade policy before the foreign government does. 
It may be of a particular interest to integrate the strategic trade policy with the hierarchical games in firm theory. It is generally argued that a proper analysis of the firm's objective function should be based on the analysis of the owner-manager relationship. A manager's objective depends on the structure of the incentives that his owner sets to motivate him. Owners often index managerial compensation to profits, sales, output, quality, and some other variables. Even if the owners want to maximize profits, the incentive system they design may imply managerial incentives which are different from profit maximization.

Sklivas (1987) addresses the question of whether firms with separate owners and managers maximize profits. He examines an oligopoly where managers compete in quantities or prices, as in the Cournot or Bertrand models, and owners choose their managers' incentives. Owner evaluates his manager's performance according to a measure, which is a linear combination of his firm's profits and revenues. The higher is this measure, the higher is the manager's payment. When managers compete in quantities, firms in the owner-manager game produce outputs greater than the output in the standard ${ }^{1}$ Cournot model. This results in firms' having lower profits than the profit-maximizing firms in the standard Cournot model. When managers compete in prices, firms receive higher profits than in the standard Bertrand model.

In what follows, Chapter 2 is concerned with strategic managerial delegation and its implications for international trade policy. Corporate firms, with separation of management and ownership, compete in international markets. We ask how trade policy affects the incentive to managers, which in turn affects the impact of trade policy on prices and quantities. This chapter combines the models of Collie (1994) and Sklivas (1987) in a single integrated analytical framework. The integrated model will have a modest contribution to the literature by

\footnotetext{
${ }^{1}$ In the standard Cournot or Bertrand model, ownership and management are not separated for each firm.
} 
investigating the strategic trade policies under duopoly in a multistage game with endogenous timing of trade policy when the ownership and the management are separated for each firm.

Trade policy is modeled as a multi-stage game and the timing of trade policy decisions is endogenous. At the beginning of the game, stage zero, home and foreign governments independently and simultaneously choose whether to set trade policy at stage one or at stage two. Then, at the chosen stage, each government sets its trade policy to maximize its national welfare. The home government uses an import tariff to shift rent from the foreign firm and a production subsidy to correct the domestic distortion due to imperfect competition. The foreign government uses an export subsidy to shift profits from the home firm to the foreign firm. If, at stage zero, both governments choose to set trade policy at the same stage of the game, then the outcome will be a simultaneous-move trade policy game. If the home [foreign] government chooses to move at stage one and the foreign [home] government chooses to move at stage two, then the outcome will be a Stackelberg game where the home [foreign] government is the Stackelberg leader. At stage three the owners will simultaneously write and announce contracts with their managers that specify how they will be rewarded. Finally, the managers will simultaneously choose their firms' outputs. The appropriate solution for this multistage game is the subgame perfect equilibrium, which is obtained by applying the Nash equilibrium to all the stages of the game by the process of backward induction.

The results show that in the subgame perfect equilibrium of the trade policy game, the home government sets its tariff and production subsidy at stage one and the foreign government sets its export subsidy at stage two. By setting trade policy at stage one the home government commits itself to a lower tariff and production subsidy than in the Nash equilibrium of the simultaneous-move game, and this encourages the foreign government to use a larger export 
subsidy than in the Nash equilibrium of the simultaneous-move game. As a result both countries are better off when the home government is the Stackelberg leader than in the simultaneous-move game. The home country benefits from a larger foreign export subsidy, and the foreign country gains from facing a lower tariff and production subsidy. The conclusion for trade policy is that imperfect competition does not provide an economic rationale for countervailing duties since the home country should commit not to use countervailing duties. When compared to those of Collie (1994), our results show that home and foreign welfares are higher, when the ownership and the management are separated for each firm.

Chapter 3 of the dissertation is about the convergence of economic growth which is one of the most important issues in modern economics. In a world in which countries exchange goods, factors, and ideas; international linkages are what drive any convergence process. Though there is evidence of income convergence among some of the wealthy countries (Baumol, 1986; Baumol et al., 1989), it is not obvious why some subsets of these countries exhibit greater convergence than others, while other subsets of countries display no convergence tendencies at all. This chapter analyzes this issue from the perspective of trade's contribution to the process. It examines the relationship between international trade and income convergence among countries by focusing on groups of countries forming major trade partners.

In analyzing the factors that determine the extent of intra-industry trade in an intercountry context, Linder (1961) advanced the hypothesis that the extent of trade in differentiated products will be the greater, the more similar are income levels among the trading countries. This hypothesis reflects the assumption that similarities in income levels are associated with similarities in demand structures. The results of Chapter 3 are not sufficient to differentiate between the hypothesis that countries that trade a great deal with one another tend to converge, 
and the alternative hypothesis that similar countries tend to trade more. However, an analysis of the relationship between trade liberalization and income convergence (Ben-David, 1993, 1994a) suggests that it is trade liberalization that produces income convergence, rather than the other way around. Although no intra-group income convergence was evident before the trade reforms, significant convergence, together with significant increases in the volume of trade, began to occur simultaneously with the removal of the trade barriers. These findings provide evidence that it is the removal of obstacles to trade which leads to income convergence, rather than just the similarity suggested by the Linder hypothesis.

There is an extensive literature about the extent of income convergence among countries. This literature, however, is mostly based on models that determine the existence and magnitude of convergence through the common cross-country growth regressions. The primary methodology used to test for the existence of convergence in these studies was to regress growth rates on initial levels of income plus the additional factors that one wished to control for. A negative relationship between the rates of growth and the initial incomes was interpreted as implying convergence. In Chapter 3, however, convergence will be characterized by the reduction in income differentials within specific groups of countries over time.

Another difference between this research and the earlier papers is that the primary focus here is on intra-industry trade's relationship to the convergence process. Trade groups are formed on the basis of intra-industry trade among countries rather than only exports or imports. No attempt is made to analyze and extend the theoretical motivations behind the relationship between intra-industry trade and income convergence. The contribution of this research is by empirically noting the existence of such a link. 
The 1971-2002 income and trade data of 24 developed countries are included in the analysis with per capita incomes of $\$ 10,000$ or higher in 2002 . For each country, primary intraindustry trade partners are determined and trade groups are created. The behavior of income differentials within these groups is examined. The majority of these intra-industry trade-based groups exhibited significant income convergence. The hypotheses are tested to examine whether any random grouping of these same countries might produce similar results, whether the convergence within groups might be towards one country that is common to most of the groups, and whether the tendency towards convergence is considerably stronger when the basis for constructing groups is trade rather than proximity or common language.

The results show that significant income convergence is not a common outcome among countries when they are grouped randomly instead of grouping them according to their trade partners; the convergence within groups is not towards one country that is common to most of the groups, but is instead an outcome that tends to be relatively robust to the exclusion of the major trade partners that are members in most of the groups, and the tendency towards convergence appears to be considerably stronger when the basis for constructing groups is trade rather than proximity or common language.

Chapter 4 of the dissertation relates to the determinants of the intra-industry trade in a multi-country \& multi-industry framework. One group of models that has emerged through the synthesis of international economics and industrial organization includes the models of intraindustry trade. Intra-industry trade models provide an explanation for the simultaneous export and import of fairly similar goods. In these models countries' markets are characterized by imperfect competition involving differentiated products and increasing returns to scale. The opening of 
trade results in a greater product variety and an increased competition with a consequent reduction in costs and prices. In their pioneering study which fundamentally changed the way economists view the causes of international trade, Grubel and Lloyd (1975) established the extent of intra-industry trade in different industrial nations, considered some measurement issues, and investigated possible causes and consequences of such trade. To point out this fundamental change, Helpman and Krugman (1989) refer to intra-industry trade as "one of the key empirical reasons for emphasizing the role of increasing returns and imperfect competition in the world economy" (Helpman and Krugman, 1989: p.133).

Greenaway and Milner (1986) have surveyed the literature on the testing of hypotheses concerning intra-industry trade. They suggest that the hypotheses can be classified in three groups. The first group of studies identifies country-specific characteristics that influence the extent of intra-industry trade ${ }^{2}$. The empirical results show that the extent of intra-industry trade is positively correlated with country characteristics. The general consistency of the signs and the significance levels of the coefficients give support for the country-specific hypotheses.

The second group of studies has emphasized industry-specific determinants of intraindustry trade relating to scale economies, product differentiation, and imperfect competition ${ }^{3}$. Greenaway and Milner conclude that there are some systematic inter-industry characteristics of intra-industry trade, and varying degrees of support for the hypotheses, but country characteristics seem to be more important than industry characteristics in explaining intra-industry trade.

\footnotetext{
${ }^{2}$ Loertscher and Wolter (1980), Havrylyshyn and Civan (1983), Balassa (1986), and Globerman and Dean (1990).

${ }^{3}$ Culem and Lundberg (1983), Greenaway and Milner (1984), Balassa (1986), Marvel and Ray (1987), Ray (1991), Hamilton and Kniest (1991), Lundberg (1992), and Clark (1993).
} 
The final group of empirical studies analyzed policy-based hypotheses relating to tariffs, non-tariff barriers, and economic integration ${ }^{4}$. Greenaway and Milner conclude that there is no consistent empirical evidence that variations in intra-industry trade can be explained by policy interventions.

A more recent study is Kim and Oh (2001). From the cross-sectional analysis using 19701994 data, results are obtained that support the following three empirical hypotheses: The share of intra-industry trade will be large: (a) if the two economies are of similar size, (b) if the capitallabor endowment ratio of both countries is similar, and (c) if the total size of the two economies is large.

In the literature, one group of authors has concentrated on the measurement of intraindustry trade. Another group has taken econometric approaches and attempted to test the theory of intra-industry trade with data on an observed country or a group of countries. This research belongs to the second group. This study provides recent evidence on determinants of the intraindustry trade in a multi-country \& multi-industry framework. Bilateral trade data of 1998-2002 period at three-digit SITC (Standard International Trade Classification) industry groups are used for 24 developed countries.

First, a theoretical summary of a two-country model based on product differentiation and economies of scale will be provided, following Helpman (1981) and Helpman and Krugman (1985). Then, using this model, the determinants of bilateral intra-industry trade are analyzed in the trade of each country with every other country in each industry category. Some hypotheses

${ }^{4}$ Balassa (1986), Bergstrand (1983), Havrylyshyn and Civan (1983), Toh (1982), Caves (1981), and Loertscher and Wolter (1980). 
that are tested in this study investigate the effect of the following country characteristics on the bilateral intra-industry trade: average per capita income, average country size, income and size difference, distance, common border, trade orientation, participation in economic integration systems and common language.

Trade data of 2002 for 24 developed countries are included in the analysis with per capita incomes of $\$ 10,000$ or higher. In the order of decreasing per capita GNP, these countries are Luxembourg, Norway, USA, Switzerland, Japan, Denmark, Ireland, Iceland, United Kingdom, Netherlands, Sweden, Finland, Austria, Canada, Germany, Belgium, France, Australia, Italy, Israel, Spain, New Zealand, Portugal, and Greece. The investigation covers 44 three-digit industry groups which belong to Section 7 of the Standard International Trade Classification (SITC) system.

The hypotheses put forward in the theoretical literature in regard to common country characteristics are generally confirmed by the empirical results. Thus, the extent of intra-industry trade is positively correlated with average income levels, average country size, and the existence of common borders and it is negatively correlated with income inequality, inequality in country size, and distance. All the variables are highly significant.

We also found that the extent of intra-industry trade and participation in the EU, and the NAFTA are positively correlated, with all the coefficients being highly significant in the relevant equations. Also, the language variables have the expected positive sign whenever they are statistically significant, which is the case in most instances. 


\section{Chapter 2. Export Subsidies, Countervailing Tariffs and Managerial Incentives in Strategic Trade Policy Games}

\section{Introduction}

International trade has grown rapidly in the last decades. Reductions in tariffs and improvements in communication have lowered the costs of importing goods produced in other countries. Moreover, new producers are emerging as developing countries industrialize. As a result, producers in developed countries are facing increased competition from foreign producers. As an example, for many years export promotion was a large issue in Japanese government policy. Government officials recognized that Japan needed to import to grow and develop, and it needed to generate exports to pay for those imports. Japan's methods of promoting exports have taken two paths. The first was to develop world-class industries that can initially substitute for imports and then compete in international markets. The second was to provide incentives for firms to export. The 1970s and 1980s saw the emergence of policies to restrain exports in certain industries. The great success of some Japanese export industries created a reaction in other countries. Under GATT guidelines, nations have been reluctant to raise tariffs or impose import quotas. Instead, they have tried to convincing the exporting country to "voluntarily" restrain exports of the offending product. In the 1980s, Japan was quite willing to carry out such export restraints. Among Japan's exports to the Unites States, steel, color television sets, and automobiles all were subjects to such restraints at various times.

While there are many reasons for the current challenges facing American-owned auto manufacturers, Japan's trade policies and the impact of Japan's sustained currency manipulation stand out among the primary causes. With the progressive lowering of tariffs and other barriers to 
trade, exchange rates have taken on a larger component of competitive advantage. This subsidy has both facilitated the expansion of Japanese companies in the U.S. and succeeded in keeping American-built automobiles out of Japan. In 2004, the U.S.-Japan bilateral automotive trade deficit reached $\$ 44.2$ billion, making it the largest sectoral trade deficit the United States maintains with any country. In 2004, automotive trade represented over two-thirds of the total U.S.-Japan deficit.

The assumptions of constant returns to scale and perfect competition are often violated in the real world. Traditional trade theory based on perfect competition does not effectively explain phenomena such as intra-industry trade and the high volume of trade between similar countries. Moreover, such models failed to successfully integrate some important policy related considerations, such as increasing returns to scale, learning-by-doing, $\mathrm{R} \& \mathrm{D}$, and inter-firm strategic rivalries. Effective analysis of these topics requires imperfect competition, which together with increasing returns to scale is one of the main characteristics of many of today's industries, especially of those in the industrialized countries. As new theories of imperfectly competitive markets have developed, game-theoretic approach of strategic trade policy began to emerge in the early 1980's.

As a strategic trade policy instrument, an export subsidy used by the foreign government could be "countervailed" by a domestic import tariff. The interesting point about these countervailing effects is that they do not eliminate incentives to use active strategic trade policy, and the policy equilibrium normally implies positive subsidies and tariffs. Collie (1994) examines a country's optimal response to foreign export subsides. In his model, the home government uses an import tariff to extract rents from the foreign firm and a production subsidy to correct the 
domestic distortion due to imperfect competition. The foreign government uses an export subsidy to shift profits from the home firm to the foreign firm. He shows that the unique equilibrium sequence of moves of the governments is that the home government announces its trade policy before the foreign government does.

It may be of a particular interest to integrate the strategic trade policy with the hierarchical games in firm theory. Traditional economic theory considers firms as economic agents with the single objective of profit maximization. Some have criticized this as being simplistic, arguing that real firms may have a different goal. Several theories have suggested that large firms are more concerned with maximizing revenues or market shares rather than profits. Recent advances in international trade theory emphasize strategic behavior among firms of different countries and its implication for trade policy. With the separation of ownership, management, and workers various incentive structures exist within a modern corporation. In order to correctly assess the policy intervention in international trade, it is important to understand how trade policies affect intra-firm incentives and vice versa.

It is generally argued that a proper analysis of the firm's objective function should be based on the analysis of the owner-manager relationship. A manager's objective depends on the structure of the incentives that his owner sets to motivate him. Owners often index managerial compensation to profits, sales, output, quality, and some other variables. Even if the owners want to maximize profits, the incentive system they design may imply managerial incentives which are different from profit maximization. The principal (firm owner) can distort the incentives of his agents (firm managers) in order to affect the outcome of the competition between his agent and competing agents. In general, the owner of a firm will adjust his managers' incentives in such a way that it will cause rival agents to change their behavior in favor of that firm. 
Sklivas (1987) addresses the question of whether firms with separate owners and managers maximize profits. He examines an oligopoly where managers compete in quantities or prices, as in the Cournot or Bertrand models, and owners choose their managers' incentives. Owner evaluates his manager's performance according to a measure, which is a linear combination of his firm's profits and revenues. The higher is this measure, the higher is the manager's payment. When managers compete in quantities, firms in the owner-manager game produce outputs greater than the output in the standard ${ }^{5}$ Cournot model. This results in firms' having lower profits than the profit-maximizing firms in the standard Cournot model. When managers compete in prices, firms receive higher profits than in the standard Bertrand model.

One aspect of managerial incentives analyzed in the principal-agent literature is the strategic delegation of price and quantity fixing decisions. Strategic delegation refers to the design of an incentive payment scheme to the manager, independent of considerations like moral hazard or adverse selection. If a duopoly market consists of a profit-maximizing firm and a firm in the administration of a manager who is instructed to maximize sales, the second firm may earn higher profits even when both firms face the same cost function. Hence there is an incentive to set up a non-profit maximizing objective for the manager ${ }^{6}$.

This paper is concerned with strategic managerial delegation and its implications for international trade policy. Corporate firms, with separation of management and ownership, compete in international markets. We ask how trade policy affects the incentive to managers, which in turn affects the impact of trade policy on prices and quantities. Our paper combines the models of Collie (1994) and Sklivas (1987) in a single integrated analytical framework. The

\footnotetext{
${ }^{5}$ In the standard Cournot or Bertrand model, ownership and management are not separated for each firm.

${ }^{6}$ See Vickers (1985), Fershtman and Judd (1987), Sklivas (1987), and Katz (1991).
} 
integrated model will have a modest contribution to the literature by investigating the strategic trade policies under duopoly in a multistage game with endogenous timing of trade policy when the ownership and the management are separated for each firm.

In what follows, trade policy is modeled as a multi-stage game and the timing of trade policy decisions is endogenous. At the beginning of the game, stage zero, home and foreign governments independently and simultaneously choose whether to set trade policy at stage one or at stage two. Then, at the chosen stage, each government sets its trade policy to maximize its national welfare. The home government uses an import tariff to shift rent from the foreign firm and a production subsidy to correct the domestic distortion due to imperfect competition. The foreign government uses an export subsidy to shift profits from the home firm to the foreign firm. If, at stage zero, both governments choose to set trade policy at the same stage of the game, then the outcome will be a simultaneous-move trade policy game. If the home [foreign] government chooses to move at stage one and the foreign [home] government chooses to move at stage two, then the outcome will be a Stackelberg game where the home [foreign] government is the Stackelberg leader. At stage three the owners will simultaneously write and announce contracts with their managers that specify how they will be rewarded. Finally, the managers will simultaneously choose their firms' outputs. The appropriate solution for this multistage game is the subgame perfect equilibrium, which is obtained by applying the Nash equilibrium to all the stages of the game by the process of backward induction.

The results show that in the subgame perfect equilibrium of the trade policy game, the home government sets its tariff and production subsidy at stage one and the foreign government sets its export subsidy at stage two. By setting trade policy at stage one the home government commits itself to a lower tariff and production subsidy than in the Nash equilibrium of the 
simultaneous-move game, and this encourages the foreign government to use a larger export subsidy than in the Nash equilibrium of the simultaneous-move game. As a result both countries are better off when the home government is the Stackelberg leader than in the simultaneous-move game. The home country benefits from a larger foreign export subsidy, and the foreign country gains from facing a lower tariff and production subsidy. The conclusion for trade policy is that imperfect competition does not provide an economic rationale for countervailing duties since the home country should commit not to use countervailing duties. When compared to those of Collie (1994), our results show that home and foreign welfares are higher, home firm's profits are lower, and foreign firm's profits are higher in each of the three games, i.e. simultaneous-move trade policy game, Stackelberg game when the home government is the Stackelberg leader, and Stackelberg game when the foreign government is the Stackelberg leader. 


\section{Literature Review}

\subsection{Imperfect Competition and International Trade: Emergence of the Strategic Trade Policies}

The inclusion of models of imperfect competition into the international trade theory has been one of the most important developments in the economic theory during the 1980's. Some of the principal research areas of this literature are as follows:

First is the relation between trade policy and the market power of domestic firms. Many economists have noted that international trade reduces the market power of domestic firms, and argued that protection increases domestic market power. Bhagwati (1965) firstly and then Krishna (1984) comprehensively demonstrated that the effects of protection depend on the form it takes - specifically, quantitative restrictions such as import quotas create more domestic market power than tariffs.

Second is the role of price discrimination and "dumping" in international markets. A duopoly model of dumping was developed by Brander (1981) and analyzed fully by Brander and Krugman (1983). In a perfectly symmetrical situation with the complete absence of comparative advantage, it is shown that if the transport costs are not too large and if the firms behave in a Cournot fashion, trade will nevertheless result, as long as price subtracted by transportation cost exceeds marginal cost.

A third research area is the industry structure that is most open to analysis, which is the monopolistic competition. This has been analyzed in detail by Krugman (1979), Lancaster (1980), Helpman (1981), and many others. The particular importance of this analysis is the 
difference it shows between intra-industry trade, based on product diversity and increasing returns to scale, and inter-industry trade, explained by the factor endowment considerations.

Another research area attempts to explore the possibility that government action can serve a "strategic" role in giving domestic firms an advantage in oligopolistic competition by shifting oligopoly rents from foreign to domestic firms. The starting point of this debate was several papers by Brander and Spencer (1981, 1983, and 1985). One of the pioneering models of Brander and Spencer, which made the main contribution to the emergence of the literature on strategic trade policies, will be examined in the next subsection.

The basic idea of strategic trade policy to shift rents has been criticized from many points of view ${ }^{7}$. First, the policy implications are highly sensitive to the changes in the specific assumptions of the model. Second, policymakers must consider general equilibrium effects because industries compete for scarce special factors within a country. Third, rent-shifting by governments will probably cause rent-seeking activities by private agents that are not generally consistent with the interests of the society.

\subsection{The Pioneering Brander and Spencer (1985) Model}

Perhaps the most robust finding in the analysis of strategic trade policy is that imperfect competition of the oligopoly type almost always creates clear incentives for government intervention - “...government intervention can raise national welfare by shifting oligopoly rents from foreign to domestic firms...(and therefore) government policies can serve the "strategic"

\footnotetext{
${ }^{7}$ For a survey of these criticisms, see Helpman and Krugman (1989).
} 
purpose of altering the subsequent incentives of firms, acting as a deterrent to foreign competitors" (Krugman, 1989: p.1201).

The idea of profit shifting can be explained most easily with reference to the BranderSpencer (1985) model in which a domestic government decides in the first stage on a linear export subsidy and, in the second stage, a domestic firm and a foreign firm compete in quantities on a third market. In the absence of government intervention, the equilibrium in the BranderSpencer model corresponds to the Cournot (Nash) solution. Then one government decides to give an export subsidy to let its firm to produce the output that corresponds to the Stackelberg leader position. As a result the total amount of sales increases, the leading country's total profit increases; meanwhile, the follower's profit is reduced because the follower sells a lower amount than it would without the intervention. Even without intervention, each duopolist would have an incentive to take the position of a Stackelberg leader if its rival were satisfied to act as a follower, but moving from a Cournot equilibrium to a leadership position is not considered a "credible choice" for either firm. In the presence of government intervention, however, an expansion of the subsidized firm's output is regarded as a credible choice by its rival because an expansion would be privately profitable even if the rival would not reduce its output. "A subsidy to the cost of producing extra output makes it in the firm's interest to expand output, even taking the other firm's output as given. Therefore the firm's expansion of output is credible. The rival firm can best respond by contracting output" (Brander, 1986: p.28).

The Brander-Spencer analysis of shifting rents has been criticized from many viewpoints. First is the dependence of trade policy recommendations on the nature of competition between firms, analyzed by Eaton and Grossman (1986). They show that the Brander-Spencer argument for export subsidies depends on the assumption of Cournot competition and that replacing the 
Cournot with Bertrand assumption reverses the policy recommendation; for the home firm to increase its profits, the government has to impose not an export subsidy, but an export tax.

Second, policy-makers must consider general equilibrium effects because industries compete for scarce special factors within a country. This objection has been presented by Dixit and Grossman (1984). In general equilibrium, an export industry can expand only by taking resources away from other domestic industries. So an export subsidy, while it lowers the marginal cost in the targeted industry, will raise marginal cost in other sectors. Thus, in industries that are not targeted the effect will be the reverse of deterrence.

Third, the extent for raising national income through strategic trade policies is negligible. This argument, developed by Dixit (1984), rests on potential competition through entry. An industry in which firms earn profits will be attractive to new entrants and if entry actually takes place, increased competition will limit or eliminate the profits of the subsidizing country.

Finally, the Brander-Spencer analysis assumes that the government can commit itself to a trade policy before firms make their decisions. They also do not consider the possible reactions of foreign governments. However, firms also make strategic moves to affect government decisions and governments must consider the possibility of foreign reactions. Many of these models have been analyzed by Dixit and Kyle (1985).

\subsection{Countervailing Tariffs: The model of Collie (1994)}

Much of the literature of strategic trade policy assumes the sequence of moves of rival governments as exogenously given. For example, Collie (1991) examines the optimal export subsidy set by a foreign government when a home government responds to a foreign export subsidy with a home import tariff. In his model, the foreign government is exogenously assigned 
the role of a Stackelberg leader and the home government the role of a Stackelberg follower. He finds that the optimal domestic response to a foreign export subsidy is to retaliate with a partial countervailing tariff and the extent of countervailing is sufficient in most cases to eliminate the foreign country's incentive to use an export subsidy.

To correct the modeling problem of exogenously given sequence of moves of the governments, Collie (1994) extends his earlier work by allowing the timing of trade policy decisions to be endogenous. The home government uses an import tariff to extract rent from the foreign firm and a production subsidy to correct the domestic distortion due to imperfect competition. The foreign government uses an export subsidy to shift profits from the home firm to the foreign firm. The results of Collie (1994) show that the home government setting trade policy at stage one and the foreign government setting trade policy at stage two is the Nash equilibrium. Both countries are better off when the home government is the Stackelberg leader. An immediate conclusion is that imperfect competition cannot explain the existence of countervailing duties since the home government commits not to use them in equilibrium.

\subsection{The Strategic Choice of Managerial Incentives}

Economists have long considered the objective function of large corporations. Several theories argue that in the firms with separate owners and managers, the interests of managers - their income, status, power, security, etc. - lie partly with sales and growth rather than purely with profits. Agency theory, going back to Jensen and Meckling (1976), Holmstrom (1979), and many other related papers, suggests that, if the objective function of the manager is different from the objective function of the owner, one may observe behavior that deviates from profit maximization. For example, managers may have a strategy of diversification to increase their job security or to assure the long-run survival of the firm (Amihud and Lev, 1981; Donaldson and 
Lorsch, 1983). Managers may want to secure their positions by choosing irreversible projects that require expertise owned by only the current management (Schleifer and Vishny, 1989). Kedia (2002) finds empirical support for the idea that top management compensation is related to sales maximization in an oligopoly setting.

Fershtman and Judd (1987) model a case where owners who are interested in profit maximization may find it optimal to include sales maximization in the manager's objective function in an oligopoly setting. The nature of the optimal incentive structure critically depends on the nature of oligopolistic competition. In the case of Cournot quantity competition, Fershtman and Judd (1987) prove that each owner wants to motivate his manager toward high production in order to get rival managers to reduce their output. Therefore, in equilibrium, owners will give a positive incentive for sales. On the other hand, if firms compete in price, each owner wants his manager to set a high price, encouraging rival managers to also raise their prices. Therefore, with price competition, owners will pay managers to keep sales low.

Sklivas (1987) shows that the separation of ownership and management gives the owners the opportunity to commit their managers to non-profit-maximizing behavior. When managers compete in quantities, firms in the owner-manager game act as profit maximizers with less than true cost. They produce outputs greater than the Cournot output. This results in firms' having lower profits than the profit-maximizing firms in the standard Cournot model. When managers compete in prices, the consequences of the separation of ownership and management reverse; firms act as profit maximizers with greater than true cost, with the result that prices are higher. Firms also receive higher profits than in the standard Bertrand model. 


\section{The Model}

There are two countries in the model: the home and the foreign country. Home country variables are denoted by the subscript 1 and foreign country variables by the subscript 2 . The industry that is analyzed is a Cournot duopoly with one firm in each country, and the home and foreign markets are assumed to be segmented. Each firm has one owner and one manager. The home and foreign firms have constant marginal $\operatorname{costs} c_{1}$ and $c_{2}$, respectively. With segmented markets and constant marginal cost, the home market can be analyzed independently of the foreign market. The home firm produces $x_{1}$ for the home market and the foreign firm exports $x_{2}$ to the home market, hence total sales in the home market are $X=x_{1}+x_{2}$. Price in the home market is given by the linear inverse demand function $P=a-b X$. While the home government uses a specific import tariff of $t$ per unit and a production subsidy of $s$ per unit, the foreign government uses an export subsidy of $e$ per unit.

Trade policy is modeled as a multi-stage game and the timing of trade policy decisions is endogenous. At the beginning of the game, stage zero, home and foreign governments independently and simultaneously choose whether to set trade policy at stage one or at stage two. Once they have chosen when to set trade policy their decisions become common knowledge and they are committed to this timing of moves in the game. Then, at the chosen stage, each government sets its trade policy to maximize its national welfare. The home government uses an import tariff to shift rent from the foreign firm and a production subsidy to correct the domestic distortion due to imperfect competition. The foreign government uses an export subsidy to shift profits from the home firm to the foreign firm. If, at stage zero, both governments choose to set trade policy at the same stage of the game, then the outcome will be a simultaneous-move trade policy game. If the home [foreign] government chooses to move at stage one and the foreign 
[home] government chooses to move at stage two, then the outcome will be a Stackelberg game where the home [foreign] government is the Stackelberg leader. At stage three the owners will simultaneously write and announce contracts with their managers that specify how they will be rewarded. Finally, the managers will simultaneously choose their firms' outputs. The appropriate solution for this multistage game is the subgame perfect equilibrium, which is obtained by applying the Nash equilibrium to all the stages of the game by the process of backward induction.

Owner $i$ measures his manager's performance according to some function of his firm's profits $\left(\Pi_{i}\right)$ and revenues $\left(R_{i}\right)$, which are observed indicators of performance. We call this measure $g_{i}, i=1,2$. The higher is $g_{i}$, the higher is manager $i$ 's bonus. Because firm $i$ 's output, $x_{i}$, does not enter manager $i$ 's utility directly, the owner links the manager's reward to $x_{i}$ (as well as to $x_{j}$ ) through a function of $g_{i}$. So, let $A_{i}+B_{i} g_{i}(.,$.$) represent manager i$ 's incentives, where $A_{i}$ and $B_{i}$ are nonnegative reals. For simplicity, we make $g_{i}$ a linear combination of profits and revenues:

$$
\begin{aligned}
& g_{i}=\lambda_{i} \Pi_{i}\left(x_{1}, x_{2}\right)+\left(1-\lambda_{i}\right) R_{i}\left(x_{1}, x_{2}\right) \\
& =R_{i}\left(x_{1}, x_{2}\right)-\lambda_{i} C_{i}\left(x_{i}\right), i=1,2 \text {, where } \\
& C_{i}\left(x_{i}\right)=c_{i} x_{i} \\
& \Pi_{1}\left(x_{1}, x_{2}\right)=\left(P-c_{1}+s\right) x_{1} \quad \Pi_{2}\left(x_{1}, x_{2}\right)=\left(P-\mathrm{c}_{2}-t+e\right) x_{2} \\
& R_{1}\left(x_{1}, x_{2}\right)=(P+s) x_{1} \quad R_{2}\left(x_{1}, x_{2}\right)=(P-t+e) x_{2}
\end{aligned}
$$

The owner $i$ has full information about his manager's costs and actions. The owner's goal is simply to determine what action he wants the manager to choose, and to design an incentive payment to induce the manager to choose that action. For the owner $i$ 's choice of $\lambda_{i}$, let $x_{i}\left(\lambda_{i}, \lambda_{j}^{*}\right)$ denote the action that manager $i$ can take, given owner $j$ 's choice of $\lambda_{j}^{*}$ and manager $j$ 's choice of $x_{j}^{*}$. The problem, from the viewpoint of owner $i$, of determining $\lambda_{i}$ and designing the optimal incentive scheme $A_{i}+B_{i} g_{i}(.,$.$) can be written as$ 


$$
\max _{\lambda_{i}, \mathrm{~A}_{\mathrm{i}}, B_{i}} \Pi_{i}\left(x_{1}^{*}\left(\lambda_{i}, \lambda_{j}^{*}\right), x_{2}^{*}\left(\lambda_{i}, \lambda_{j}^{*}\right)\right)-\left(A_{i}+B_{i} g_{i}\left(x_{1}^{*}\left(\lambda_{i}, \lambda_{j}^{*}\right), x_{2}^{*}\left(\lambda_{i}, \lambda_{j}^{*}\right)\right)\right)
$$

such that $A_{i}+B_{i} g_{i}\left(x_{1}^{*}\left(\lambda_{i}, \lambda_{j}^{*}\right), x_{2}^{*}\left(\lambda_{i}, \lambda_{j}^{*}\right)\right) \geq w_{0, i}$

$$
A_{i}+B_{i} g_{i}\left(x_{1}^{*}\left(\lambda_{i}, \lambda_{j}^{*}\right), x_{2}^{*}\left(\lambda_{i}, \lambda_{j}^{*}\right)\right) \geq A_{i}+B_{i} g_{i}\left(x_{1}\left(\lambda_{i}, \lambda_{j}^{*}\right), x_{2}^{*}\left(\lambda_{i}, \lambda_{j}^{*}\right)\right)
$$

where $w_{0, i}$ denotes the reservation wage of manager $i$.

Condition (1) imposes the constraint that each manager must receive at least his reservation wage since one possible "action" is not to participate; this is the participation constraint. To minimize the salary of his manager, as it is a loss term in the objective function of the owner, the owner $i$ must then equate it to the reservation wage $w_{0, i}$.

Condition (2) imposes the constraint that the manager $i$ will find it optimal to choose $x_{i}^{*}\left(\lambda_{i}, \lambda_{j}^{*}\right)$; this is the incentive compatibility constraint. As we are going to define in Section 3.1, $x_{i}^{*}$ that enters into the objective function of owner $i$ is actually the argument that maximizes $g_{i}\left(x_{i}, x_{j}^{*}\right)$. Therefore, for any positive real $B_{i}$ the incentive compatibility condition will always be satisfied. Thus, the owner $i$ can choose $B_{i}$ arbitrarily small, as long as it is positive. Then $A_{i}$ can, in effect, be chosen to be arbitrarily close to $w_{o, i}$ and the objective function of owner i will be arbitrarily close to $\Pi_{i}\left(x_{1}^{*}\left(\lambda_{i}, \lambda_{j}^{*}\right), x_{2}^{*}\left(\lambda_{i}, \lambda_{j}^{*}\right)\right)-w_{0, i}$. Normalizing $w_{0, i}$ to zero for simplicity, we will hereafter assume, as in Sklivas (1987), that the problem of owner $i$ is to maximize $\Pi_{i}\left(x_{1}^{*}\left(\lambda_{i}, \lambda_{j}^{*}\right), x_{2}^{*}\left(\lambda_{i}, \lambda_{j}^{*}\right)\right)$ over $\lambda_{i}$ whereas the problem of manager $i$ is to maximize $\mathrm{g}_{\mathrm{i}}\left(x_{i}\left(\lambda_{i}, \lambda_{j}^{*}\right), x_{j}^{*}\left(\lambda_{i}, \lambda_{j}^{*}\right)\right)$ over $x_{i}$ 


\subsection{Stage 3: Managers choose their firms' outputs}

The firms simultaneously and independently choose their outputs to maximize $g_{i}$ given $s, t, e, \lambda_{1}$, and $\lambda_{2}$.

Definition: $\left(x_{1}^{*}, x_{2}^{*}\right)$ is a Nash equilibrium in the managers' subgame if and only if

$$
\begin{aligned}
& x_{i}^{*}=\operatorname{argmax} g_{i}\left(x_{i}, x_{j}^{*}\right), i, j=1,2, i \neq j . \\
& g_{1}=(P+s) x_{1}-\lambda_{1} c_{1} \mathrm{x}_{1} \\
& \quad=\left(a-b\left(x_{1}+x_{2}\right)+s\right) x_{1}-\lambda_{1} c_{1} x_{1} \\
& g_{2}=(P-\mathrm{t}+e) x_{2}-\lambda_{2} c_{2} x_{2} \\
& \quad=\left(a-b\left(x_{1}+x_{2}\right)-\mathrm{t}+e\right) x_{2}-\lambda_{2} c_{2} x_{2}
\end{aligned}
$$

Assuming the home market is supplied by both home production and imports, the first-order conditions for a Cournot equilibrium are:

$$
\begin{aligned}
& \frac{\partial g_{1}}{\partial x_{1}}=a-b\left(x_{1}+x_{2}\right)+s-b x_{1}-\lambda_{1} c_{1}=0 \\
& \frac{\partial g_{2}}{\partial x_{2}}=a-b\left(x_{1}+x_{2}\right)-t+e-b x_{2}-\lambda_{2} c_{2}=0
\end{aligned}
$$

Hence we find manager $i$ 's best-response function, $\phi_{i}\left(x_{j} ; \lambda_{i}\right)$, by maximizing $g_{\mathrm{i}}($.$) over x_{\mathrm{i}}$. As $\lambda_{\mathrm{i}}$ is decreased, costs are weighted less, and $\phi_{i}($.$) shifts out. So, decreasing \lambda_{\mathrm{i}}$ commits manager $i$ to more "aggressive" behavior, i.e. for every $x_{\mathrm{j}}$, manager $i$ responds with a greater $x_{\mathrm{i}}$ :

$$
\begin{aligned}
& x_{1}=\frac{a-b x_{2}+s-\lambda_{1} c_{1}}{2 b}=\phi_{1}\left(x_{2} ; \lambda_{1}\right) \\
& x_{2}=\frac{a-b x_{1}-t+e-\lambda_{2} c_{2}}{2 b}=\phi_{2}\left(x_{1} ; \lambda_{2}\right)
\end{aligned}
$$


Solving Eqs. (3) and (4) simultaneously, we get the Nash equilibrium quantities and price as:

$$
\begin{aligned}
& x_{1}=\frac{1}{3} \frac{a+2 s-2 \lambda_{1} c_{1}+t-e+\lambda_{2} c_{2}}{b} \\
& x_{2}=\frac{1}{3} \frac{a-s+\lambda_{1} c_{1}-2 t+2 e-2 \lambda_{2} c_{2}}{b} \\
& P=\frac{1}{3}\left(a+t-s-e+\lambda_{1} c_{1}+\lambda_{2} c_{2}\right)
\end{aligned}
$$

Notice that as the owner $i$ makes his manager more aggressive by decreasing $\lambda_{\mathrm{i}}$, his own firm's output increases, while his rival's decrease in equilibrium.

\subsection{Stage 2: Owners choose their managers' incentives ${ }^{8}$}

The owners will simultaneously write and announce contracts with their managers that specify how they will be rewarded.

Definition: $\left(\lambda_{1}^{*}, \lambda_{2}^{*}\right)$ is a Nash equilibrium in the owners' subgame if and only if

$$
\begin{aligned}
\lambda_{i}^{*}= & \operatorname{argmax} \Pi_{i}\left(x_{1}^{*}\left(\lambda_{i}, \lambda_{j}^{*}\right), x_{2}^{*}\left(\lambda_{i}, \lambda_{j}^{*}\right)\right), i, j=1,2, i \neq j \\
& \Pi_{1}\left(x_{1}, x_{2}\right)=\left(P-c_{1}+s\right) x_{1} \\
& \frac{\partial}{\partial \lambda_{1}} \Pi_{1}\left(x_{1}, x_{2}\right)=0 \\
& \Rightarrow b x_{1}-2\left(P-c_{1}+s\right)=0 \\
& \Pi_{2}\left(x_{1}, x_{2}\right)=\left(P-c_{2}-\mathrm{t}+e\right) x_{2} \\
& \frac{\partial}{\partial \lambda_{2}} \Pi_{2}\left(x_{1}, x_{2}\right)=0 \\
& \Rightarrow b x_{2}-2\left(P-c_{2}-\mathrm{t}+e\right)=0
\end{aligned}
$$

\footnotetext{
${ }^{8}$ To see some of the calculations in detail, see Appendix.
} 
Using the Nash equilibrium quantities and price in (5) and solving Eqs. (6) and (7) simultaneously, we get $\lambda_{1}^{*}$ and $\lambda_{2}^{*}$ as:

$$
\begin{aligned}
& \lambda_{1}^{*}=\frac{1}{5} \frac{-a-3 s-2 t+2 e-2 c_{2}+8 c_{1}}{c_{1}} \\
& \lambda_{2}^{*}=\frac{1}{5} \frac{-a+2 s+3 t-3 e+8 c_{2}-2 c_{1}}{c_{2}}
\end{aligned}
$$

We show in the subsections $3.3 .1,3.3 .2$, and 3.3 .3 that at the equilibrium we have $\lambda_{1}^{*}<1$ and $\lambda_{2}^{*}<1$. Substituting $\lambda_{1}^{*}$ and $\lambda_{2}^{*}$ above into (5), we get

$$
\begin{aligned}
& x_{1}=\frac{2}{5} \frac{a+3 s+2 t-2 e+2 c_{2}-3 c_{1}}{b} \\
& x_{2}=\frac{2}{5} \frac{a-2 s-3 t+3 e-3 c_{2}+2 c_{1}}{b} \\
& P=\frac{2}{5}\left(c_{1}+c_{2}+t-s-e+\frac{a}{2}\right)
\end{aligned}
$$

Why do firms choose at the equilibrium $\lambda_{1}^{*}<1, \lambda_{2}^{*}<1$ and not $\lambda_{1}^{*}=1, \lambda_{2}^{*}=1$ ? To show this, let us assume, without loss of the generality, that $s=t=e=0$. Now, if $\lambda_{1}=1$ and $\lambda_{2}=1$, then both firms will maximize their profits and the result will be a Cournot outcome. The first order conditions for this Cournot equilibrium will give:

$$
\begin{aligned}
& x_{1}=\frac{1}{3} \frac{a-2 c_{1}+c_{2}}{b}, \quad x_{2}=\frac{1}{3} \frac{a+c_{1}-2 c_{2}}{b}, \quad P=\frac{1}{3}\left(a+c_{1}+c_{2}\right) \\
& \Pi_{1}=\frac{1}{9} \frac{\left(a-2 c_{1}+c_{2}\right)^{2}}{b}, \Pi_{2}=\frac{1}{9} \frac{\left(a+c_{1}-2 c_{2}\right)^{2}}{b}
\end{aligned}
$$


Now, given the second firm sets $\lambda_{2}=1$ and maximizes its profits, it is a better strategy for firm 1 to decrease its costs $c_{1}$ so that its output and profit increase. This follows from

$$
\frac{d x_{1}}{d c_{1}}<0, \frac{d \Pi_{1}}{d c_{1}}<0 .
$$

For firm 1 to decrease its costs, the owner lets his manager maximize a linear combination of profits and revenues. Then, in the objective function of the manager, the cost term is not $c_{1}$ any more, but it is $\lambda_{1} c_{1}$, i.e.

$$
g_{1}=R_{l}\left(x_{1}, x_{2}\right)-\lambda_{1} c_{1} x_{1}, \text { where } \lambda_{1}<1
$$

But then, if the manager of firm 2 continues to operate with $c_{2}$ choosing $\lambda_{2}=1$, firm 1 would have a "cost advantage" and increase its profits while the profits of firm 2 would decrease. In other words, firm 1's unilateral deviation from profit maximization increases its profits and lowers firm 2's. So then, the best response of firm 2 is to "decrease" its costs by choosing $\lambda_{2}<1$, too.

Thus, in the owner-manager game, managers behave more aggressively than profit maximizers, i.e. $\lambda_{1}^{*}<1$ and $\lambda_{2}^{*}<1$. This results in outputs that are higher than in the Cournot model, $x_{i}^{*}\left(\lambda_{1}^{*}, \lambda_{2}^{*}\right)>x_{i}^{*}(1,1), \mathrm{i}=1,2$. Setting $\mathrm{s}=\mathrm{t}=\mathrm{e}=0$ and $c_{1}=c_{2}=c$, from Eq.(5) and Eq.(8), we see that

$$
\begin{aligned}
& x_{1}^{*}\left(\lambda_{1}^{*}, \lambda_{2}^{*}\right)=\frac{2}{5} \frac{a-c}{b}>\frac{1}{3} \frac{a-c}{b}=x_{1}^{*}(1,1) \\
& x_{2}^{*}\left(\lambda_{1}^{*}, \lambda_{2}^{*}\right)=\frac{2}{5} \frac{a-c}{b}>\frac{1}{3} \frac{a-c}{b}=x_{2}^{*}(1,1)
\end{aligned}
$$


The intuition for the result of the owners' committing their managers to non-profit maximizing behavior can be also seen in Figure 1. Figure 1 illustrates the Cournot outcome, $C$; and the outcome of the owner-manager game, $M$. In choosing $\lambda_{i}$, an owner implicitly chooses his manager's best-response function, so we can think of owners as playing a game in best response functions. Starting from point $C$, the Nash equilibrium in the managers' subgame resulting from $\lambda_{1}=1$ and $\lambda_{2}=1$, owner 1 can increase his profits by decreasing $\lambda_{1}$, which shifts $\phi_{1}\left(x_{2} ; \lambda_{1}=1\right)$ out to $\phi_{1}\left(x_{2} ; \lambda_{1}=\lambda_{1}^{*}\right)$. By committing his manager to more aggressive behavior, owner 1 moves the equilibrium quantities down along $\phi_{2}\left(x_{1} ; \lambda_{2}=1\right)$ to point $T$, and so increases $x_{1}^{*}$ and decreases $x_{2}^{*}$. This increases owner 1's profits 9 .

So, $\lambda_{1}=1$ cannot be a best response to $\lambda_{2}=1$ and point $C$, where both owners' committing their managers to profit-maximizing behavior cannot be an equilibrium. But then, $\lambda_{2}=1$ is not a best response to $\lambda_{1}=\lambda_{1}^{*}$ either, since by decreasing $\lambda_{2}$ and shifting $\phi_{2}\left(x_{1} ; \lambda_{2}=1\right)$ out to $\phi_{2}\left(x_{1} ; \lambda_{2}=\lambda_{2}^{*}\right)$, owner 2 can increase his profits. So, point $T$ is not an equilibrium, either. One can see that $\lambda_{1}^{*}$ is a best response to $\lambda_{2}^{*}$ by the fact that firm 1 's isoprofit curve is tangent to $\phi_{2}\left(x_{1} ; \lambda_{2}=\lambda_{2}^{*}\right)$ at $M$, and similarly that $\lambda_{2}^{*}$ is a best response to $\lambda_{1}^{*}$ by the fact that firm 2's isoprofit curve is tangent to $\phi_{1}\left(x_{2} ; \lambda_{1}=\lambda_{1}^{*}\right)$ at $M$.

\footnotetext{
${ }^{9}$ Note that profits increase as the isoprofit curves approach to the origin; since, for example, for a fixed $x_{1}$ value, if we decrease $x_{2}$ - that is, if we go down and approach to $x_{1}$ axis - the price will increase, since $P=a-b\left(x_{1}+x_{2}\right)$ and thus the profits of the firm 1 will increase.
} 


\subsection{Stage 1: Governments choose their trade policies ${ }^{10}$}

Each government sets its trade policy to maximize its national welfare. The welfare of the home country is given by the sum of consumer surplus, producer surplus, and government revenue. Hence, home welfare is:

$$
\begin{aligned}
& W_{I}=\int_{0}^{x_{1}^{8}+x_{2}^{8}}(a-b Q) d Q-P\left(x_{1}^{*}+x_{2}^{*}\right)+\left(P-c_{1}\right) x_{1}^{*}+s x_{1}^{*}+t x_{2}^{*}-s x_{1}^{*}
\end{aligned}
$$

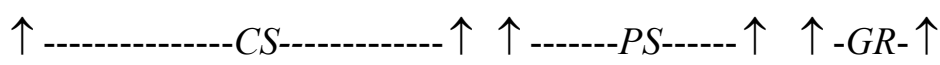

$C S$ : Consumer Surplus, PS: Producer Surplus, GR: Government Revenue

$$
\Rightarrow W_{1}=\frac{b}{2}\left(x_{1}^{*}+x_{2}^{*}\right)^{2}+\left(a-b\left(x_{1}^{*}+x_{2}^{*}\right)-c_{1}\right) x_{1}^{*}+t x_{2}^{*}
$$

The welfare of the foreign country is the profits of the foreign firm from exports less the export subsidy payments. Hence, foreign welfare is:

$$
\begin{aligned}
W_{2}= & \left(P-c_{2}-t\right) x_{2}^{*}+e x_{1}^{*}-e x_{1}^{*} \\
& \uparrow-------\Pi_{2}------\uparrow \uparrow E S P \uparrow
\end{aligned}
$$

$\Pi_{2}$ : Profits of the foreign firm, ESP: Export subsidy payments

$$
\Rightarrow W_{2}=\left(a-b\left(x_{1}^{*}+x_{2}^{*}\right)-c_{2}-t\right) x_{2}^{*}
$$

To analyze stage zero of the game there are three possible outcomes to consider: the Nash equilibrium of the simultaneous-move game; the Nash equilibrium of the Stackelberg game when the foreign government is the first mover; and the Nash equilibrium of the Stackelberg game when the home government is the first mover.

\footnotetext{
${ }^{10}$ To see some of the calculations in detail, see Appendix.
} 


\subsubsection{Simultaneous-Move Trade Policy Game}

If, at stage zero, both governments choose to set trade policy at the same stage of the game, then the outcome will be a simultaneous-move trade policy game. Both governments simultaneously and independently choose their trade policy to maximize national welfares in (9) and (10). It will be assumed that there is an interior solution where the market is supplied by both home production and imports ${ }^{11}$. Differentiating (9) and (10) we get

$$
\begin{aligned}
& \frac{\partial W_{1}}{\partial t}=0 \Rightarrow-2 b\left(x_{1}^{*}+x_{2}^{*}\right)+4\left(P-c_{1}\right)+2 b x_{1}^{*}-6 t+5 b x_{2}^{*}=0 \\
& \frac{\partial W_{1}}{\partial s}=0 \Rightarrow b\left(x_{1}^{*}+x_{2}^{*}\right)+3\left(P-c_{1}\right)-b x_{1}^{*}-2 t=0 \\
& \frac{\partial W_{2}}{\partial e}=0 \Rightarrow 3\left(P-c_{2}-t\right)-b x_{2}^{*}=0
\end{aligned}
$$

Solving Eqs. (11), (12), and (13) simultaneously and using (8) we get

$$
\begin{aligned}
x_{1}^{s} & =\frac{1}{5 b}\left(5 a-11 c_{1}+6 c_{2}\right) \\
x_{2}^{s} & =\frac{6}{5 b}\left(c_{1}-c_{2}\right) \\
P^{s} & =c_{1} \\
s^{s} & =\frac{1}{10}\left(5 a-11 c_{1}+6 c_{2}\right) \\
t^{s} & =\frac{3}{5}\left(c_{1}-c_{2}\right) \\
e^{s} & =\frac{1}{5}\left(c_{1}-c_{2}\right),
\end{aligned}
$$

11 This assumption will be valid if the foreign firm has a cost advantage, but not such a large cost advantage that home production is not worthwhile. 
where the superscript $S$ denotes the Nash equilibrium of the simultaneous-move trade policy game. Substituting the above into the formulas of $\lambda_{1}, \lambda_{2}, \Pi_{1}, \Pi_{2}, W_{1}$, and $W_{2}$ we get:

$$
\begin{aligned}
& \lambda_{1}=\frac{1}{10} \frac{-5 a+21 c_{1}-6 c_{2}}{c_{1}}<1^{12} \\
& \lambda_{2}=-\frac{1}{5} \frac{3 c_{1}-8 c_{2}}{c_{2}}<1 \\
& \Pi_{1}=\frac{1}{50 b}\left(5 a-11 c_{1}+6 c_{2}\right)^{2} \\
& \Pi_{2}=\frac{18}{25 b}\left(c_{1}-c_{2}\right)^{2} \\
& W_{1}^{s}=\frac{1}{2 b}\left(a-c_{1}\right)^{2}+\frac{18}{25 b}\left(c_{1}-c_{2}\right)^{2} \\
& W_{2}^{s}=\frac{12}{25 b}\left(c_{1}-c_{2}\right)^{2}
\end{aligned}
$$

The results of Collie (1994) model and our model in the simultaneous-move trade policy game are compared in Table 1 in the Appendix. In the Nash equilibrium, the home government uses a positive tariff and production subsidy, and the foreign government uses a positive export subsidy. Price in the home market is equal to the marginal cost of the home firm, and the home tariff is three times as large as the foreign export subsidy. In what follows, the variables of the Collie (1994) model are denoted by the superscript $C$. Our results show that $W_{1} \geq W_{1}^{C}, W_{2} \geq W_{2}^{C}$, i.e. home and foreign welfares are higher; $\Pi_{1} \leq \Pi_{1}^{C}, \Pi_{2} \geq \Pi_{2}^{C}$, i.e. home firm's profits are lower and foreign firm's profits are higher; $x_{1} \leq x_{1}^{C}, x_{2} \geq x_{2}^{C}$, i.e. home firm's output is lower and foreign firm's exports are higher; and $s \leq s^{C}, t \leq t^{C}, e \leq e^{C}$, i.e. home government's production subsidy, import tariff, and foreign government's export subsidy are lower.

\footnotetext{
${ }^{12}$ To see why $\lambda_{1}$ and $\lambda_{2}$ are less than 1 , see the Appendix.
} 


\subsubsection{Stackelberg Game when the Foreign Government is the First Mover}

If, at stage zero of the game, the foreign government decides to set its export subsidy at stage one and the home government decides to set its tariff and production subsidy at stage two, then the outcome will be a Stackelberg game with the foreign government as the Stackelberg leader. The subgame perfect equilibrium is obtained by first solving stage two for the optimal tariff and production subsidy of the home government as a function of of the foreign export subsidy set at stage one, and then using this solution to obtain the optimal foreign export subsidy. At stage two, the home government sets its tariff and production subsidy to maximize home welfare (9) given the foreign export subsidy. Assuming there is an interior solution, the first-order conditions for welfare maximization are:

$$
\begin{aligned}
& \frac{\partial W_{1}}{\partial t}=0 \Rightarrow-2 b\left(x_{1}^{*}+x_{2}^{*}\right)+4\left(P-c_{1}\right)+2 b x_{1}^{*}-6 t+5 b x_{2}^{*}=0 \\
& \frac{\partial W_{1}}{\partial s}=0 \Rightarrow b\left(x_{1}^{*}+x_{2}^{*}\right)+3\left(P-c_{1}\right)-b x_{1}^{*}-2 t=0
\end{aligned}
$$

Solving Eqs. (14) and (15) simultaneously and using (8) we get

$$
\begin{aligned}
& x_{1}=\frac{1}{b}\left(a-e-2 c_{1}+c_{2}\right) \\
& x_{2}=\frac{1}{b}\left(e+c_{1}-c_{2}\right) \\
& P=c_{1} \\
& t=\frac{1}{2}\left(e+c_{1}-c_{2}\right) \\
& s=\frac{1}{2}\left(a-e-2 c_{1}+c_{2}\right)
\end{aligned}
$$


At stage one the foreign government sets its export subsidy to maximize its national welfare, realizing that its export subsidy will affect the optimal tariff and production subsidy set by the home government at stage two. Using (16), we get

$$
\begin{aligned}
& W_{2}=\frac{1}{2 b}\left(\left(c_{1}-c_{2}\right)^{2}-e\right)^{2} \\
& \frac{\partial W_{2}}{\partial e}=0 \Rightarrow e^{F}=0,
\end{aligned}
$$

where the superscript $F$ denotes the subgame perfect equilibrium of the Stackelberg game when the foreign government is the first mover. Substituting (17) into (16) gives

$$
\begin{aligned}
& x_{1}^{F}=\frac{1}{b}\left(a-2 c_{1}+c_{2}\right) \\
& x_{2}^{F}=\frac{1}{b}\left(c_{1}-c_{2}\right) \\
& P^{F}=c_{1} \\
& t^{F}=\frac{1}{2}\left(c_{1}-c_{2}\right) \\
& s^{F}=\frac{1}{2}\left(a-2 c_{1}+c_{2}\right)
\end{aligned}
$$

Substituting the above into the formulas of $\lambda_{1}, \lambda_{2}, \Pi_{1}, \Pi_{2}, W_{1}$, and $W_{2}$ we get:

$$
\begin{array}{ll}
\lambda_{1}=\frac{1}{2} \frac{-a+4 c_{1}-c_{2}}{c_{1}}<1^{13} & \lambda_{2}=-\frac{1}{2} \frac{c_{1}-3 c_{2}}{c_{2}}<1 \\
\Pi_{1}=\frac{1}{2 b}\left(a-2 c_{1}+c_{2}\right)^{2} & \Pi_{2}=\frac{1}{2 b}\left(c_{1}-c_{2}\right)^{2} \\
W_{1}^{F}=\frac{1}{2 b}\left(a-c_{1}\right)^{2}+\frac{1}{2 b}\left(c_{1}-c_{2}\right)^{2} & W_{2}^{F}=\frac{1}{2 b}\left(c_{1}-c_{2}\right)^{2}
\end{array}
$$

\footnotetext{
${ }^{13}$ To see why $\lambda_{1}$ and $\lambda_{2}$ are less than 1 , see the Appendix.
} 
The results of Collie (1994) model and our model in the Stackelberg game when the foreign government is the first mover are compared in Table 2 in the Appendix. When the foreign government is the Stackelberg leader, the foreign government sets a zero export subsidy at stage one because it realizes that the home government will retaliate with a countervailing duty at the second stage, and as a result the home tariff is lower than in the simultaneous-move game. Price in the home market is equal to the marginal cost of the home firm. When compared to those of Collie (1994), our results show that $W_{1} \geq W_{1}^{C}, W_{2} \geq W_{2}^{C}$, i.e. home and foreign welfares are higher; $\Pi_{1} \leq \Pi_{1}^{C}, \Pi_{2} \geq \Pi_{2}^{C}$, i.e. home firm's profits are lower and foreign firm's profits are higher; $x_{2} \geq x_{2}^{C}$, i.e. foreign firm's exports are higher; $x_{1} \leq x_{1}^{C}$, i.e. home firm's output is lower if $3 c_{1}-2 c_{2} \geq a$; and $s \leq s^{\mathrm{C}}, t=t^{C}, e=e^{C}$, i.e. home government's production subsidy is lower, home government's import tariff and foreign government's export subsidy are equal to those in the Collie (1994) model.

\subsubsection{Stackelberg Game when the Home Government is the First Mover}

If, at stage zero of the game, the home government decides to set its tariff and production subsidy at stage one and the foreign government decides to set its export subsidy at stage two, then the outcome will be a Stackelberg game with the home government as the Stackelberg leader. The subgame perfect equilibrium is obtained by first solving stage two for the optimal export subsidy of the foreign government as a function of the home tariff and production subsidy set at stage one, and then using this solution to obtain the optimal home tariff and production subsidy. At stage two, the foreign government sets its export subsidy to maximize foreign welfare (8) given the home tariff and production subsidy. Assuming there is an interior solution, the first-order condition for welfare maximization is: 


$$
\frac{\partial W_{2}}{\partial e}=0 \Rightarrow 3\left(P-c_{2}-t\right)-b x_{2}^{*}=0
$$

Solving Eq. (18) and using (8), we get

$$
\begin{aligned}
& x_{1}=-\frac{1}{3} \frac{-a-4 s-3 t+4 c_{1}-3 c_{2}}{b} \\
& x_{2}=\frac{1}{2} \frac{a-2 s-3 t \lambda_{1}+2 c_{1}-3 c_{2}}{b} \\
& P=\frac{1}{6}\left(a-2 s+3 t+2 c_{1}+3 c_{2}\right) \\
& e=\frac{1}{12}\left(a-2 s-3 t+2 c_{1}-3 c_{2}\right)
\end{aligned}
$$

At stage one the home government sets its tariff and production subsidy to maximize its national welfare, realizing that its tariff and production subsidy will affect the optimal export subsidy set by the foreign government at stage two. Using (19), we get

$$
\begin{gathered}
W_{1}=\frac{1}{72 b}\left(68 c_{1}^{2}-84 c_{1} c_{2}+45 c_{2}^{2}-52 c_{1} a-6 c_{2} a+29 a^{2}+28 a s+30 a t-28 s^{2}\right. \\
\left.-60 s t-40 s c_{1}+12 s c_{2}-63 t^{2}-12 t c_{1}-18 t c_{2}\right)
\end{gathered}
$$

Solving $\frac{\partial W_{1}}{\partial s}=\frac{\partial W_{1}}{\partial t}=0$ we find

$$
\begin{aligned}
& s^{H}=\frac{1}{2}\left(a-\frac{5}{2} c_{1}+\frac{3}{2} c_{2}\right) \\
& t^{H}=\frac{1}{2}\left(c_{1}-c_{2}\right)
\end{aligned}
$$

where the superscript $H$ denotes the subgame perfect equilibrium of the Stackelberg game when the home government is the first mover. Substituting (20) into (19) gives 


$$
\begin{aligned}
& x_{1}^{H}=\frac{1}{2 b}\left(2 a-5 c_{1}+3 c_{2}\right) \\
& x_{2}^{H}=\frac{3}{2 b}\left(c_{1}-c_{2}\right) \\
& P^{H}=c_{1} \\
& e^{H}=\frac{1}{4}\left(c_{1}-c_{2}\right)
\end{aligned}
$$

Substituting the above into the formulas of $\lambda_{1}, \lambda_{2}, \Pi_{1}, \Pi_{2}, W_{1}$, and $W_{2}$ we get:

$$
\begin{aligned}
& \lambda_{1}=\frac{1}{4} \frac{-2 a+9 c_{1}-3 c_{2}}{c_{1}}<1^{14} \\
& \lambda_{2}=-\frac{1}{4} \frac{3 c_{1}-7 c_{2}}{c_{2}}<1 \\
& \Pi_{1}=\frac{1}{8 b}\left(2 a-5 c_{1}+3 c_{2}\right)^{2} \\
& \Pi_{2}=\frac{9}{8 b}\left(c_{1}-c_{2}\right)^{2} \\
& W_{1}^{H}=\frac{1}{2 b}\left(a-c_{1}\right)^{2}+\frac{3}{4 b}\left(c_{1}-c_{2}\right)^{2} \\
& W_{2}^{H}=\frac{3}{4 b}\left(c_{1}-c_{2}\right)^{2}
\end{aligned}
$$

The results of Collie (1994) model and our model in the Stackelberg game when the home government is the first mover are compared in Table 3 in the Appendix. When the home government is the Stackelberg leader, it is found to commit to a lower tariff and production subsidy than in the simultaneous-move game, and this encourages the foreign government to use a larger export subsidy. Price in the home market is equal to the marginal cost of the home firm. When compared to those of Collie (1994), our results show that $W_{1} \geq W_{1}^{C}, W_{2} \geq W_{2}^{C}$, i.e. home

\footnotetext{
${ }^{14}$ To see why $\lambda_{1}$ and $\lambda_{2}$ are less than 1 , see the Appendix.
} 
and foreign welfares are higher; $\Pi_{1} \leq \Pi_{1}^{C}, \Pi_{2} \geq \Pi_{2}^{C}$, i.e. home firm's profits are lower and foreign firm's profits are higher; $x_{1} \leq x_{1}^{C}, x_{2} \geq x_{2}^{C}$, i.e. home firm's output is lower and foreign firm's exports are higher; and $s \leq s^{C}, t=t^{C}, e \leq e^{C}$, i.e. home government's production subsidy and foreign government's export subsidy are lower whereas home government's import tariff is equal to that in the Collie (1994) model.

\subsubsection{The Timing of Trade Policy Decisions}

At stage zero the two governments each independently and simultaneously choose whether to set trade policy at stage one or at stage two. If both governments choose to set trade policy at the same stage of the game, then the outcome will be the Nash equilibrium of the simultaneous-move game. If the home government sets trade policy at stage one and the foreign government sets trade policy at stage two, then the outcome is the subgame perfect equilibrium of the Stackelberg game when the home government is the Stackelberg leader. If the foreign government sets trade policy at stage one and the home government sets trade policy at stage two, then the outcome is the subgame perfect equilibrium of the Stackelberg game when the foreign government is the Stackelberg leader. The payoff matrix for this game of timing is given in Table 4 in the Appendix. The following proposition builds up on the result of Collie (1994). Collie had shown that in the subgame perfect equilibrium of the trade policy game, the home government sets its tariff and production subsidy at stage one and the foreign government sets its export subsidy at stage two. In his paper, however, the ownership and management were not separated for each firm and thus, the firms were just maximizing their profits. 
Proposition 1: When the ownership and the management are separated for each firm, in the subgame perfect equilibrium of the trade policy game, the home government sets its tariff and production subsidy at stage one and the foreign government sets its export subsidy at stage two.

Proof: The comparison of home welfares when the home government sets trade policy at stage one with when it sets trade policy at stage two yields:

$$
\begin{aligned}
W_{1}^{S}-W_{1}^{F} & =\frac{1}{2 b}\left(a-c_{1}\right)^{2}+\frac{18}{25 b}\left(c_{1}-c_{2}\right)^{2}-\left(\frac{1}{2 b}\left(a-c_{1}\right)^{2}+\frac{1}{2 b}\left(c_{1}-c_{2}\right)^{2}\right) \\
& =\frac{11}{50 b}\left(c_{1}-c_{2}\right)^{2} \geq 0 \\
W_{1}^{H}-W_{1}^{S} & =\frac{1}{2 b}\left(a-c_{1}\right)^{2}+\frac{3}{4 b}\left(c_{1}-c_{2}\right)^{2}-\left(\frac{1}{2 b}\left(a-c_{1}\right)^{2}+\frac{18}{25 b}\left(c_{1}-c_{2}\right)^{2}\right) \\
& =\frac{3}{100 b}\left(c_{1}-c_{2}\right)^{2} \geq 0
\end{aligned}
$$

Whatever stage the foreign government sets its trade policy, home welfare is always higher if the home government sets its trade policy at stage one rather than at stage two. Therefore, setting trade policy at stage one is a dominant strategy for the home government, and hence it will obviously set trade policy at stage one.

The comparison of foreign welfares when the foreign government sets trade policy at stage one with when it sets trade policy at stage two yields:

$$
\begin{aligned}
& W_{2}^{S}-W_{2}^{H}=\frac{12}{25 b}\left(c_{1}-c_{2}\right)^{2}-\frac{3}{4 b}\left(c_{1}-c_{2}\right)^{2}=-\frac{27}{100 b}\left(c_{1}-c_{2}\right)^{2} \leq 0 \\
& W_{2}^{F}-W_{2}^{S}=\frac{1}{2 b}\left(c_{1}-c_{2}\right)^{2}-\frac{12}{25 b}\left(c_{1}-c_{2}\right)^{2}=\frac{1}{50 b}\left(c_{1}-c_{2}\right)^{2} \geq 0
\end{aligned}
$$


If the home government sets trade policy at stage one, then foreign welfare is higher if the foreign government sets trade policy at stage two rather than at stage one. Setting trade policy at stage two is the foreign country's optimal response to the home country setting trade policy at stage one, and setting trade policy at stage one is the dominant strategy for the home country. Therefore, the home government setting trade policy at stage one and the foreign government setting trade policy at stage two is the Nash equilibrium of stage zero of the game. Q.E.D.

By setting trade policy at stage one the home government commits itself to a lower tariff and production subsidy than in the simultaneous-move game, and this encourages the foreign government to use a larger export subsidy than in the simultaneous-move game. As a result both countries are better off when the home government is the Stackelberg leader than in the simultaneous-move game. The home country benefits from a larger foreign export subsidy, and the foreign country gains from facing a lower tariff and production subsidy.

Proposition 2: When the ownership and the management are separated for each firm, in the subgame perfect equilibrium of the trade policy game, the welfares of both countries are higher when compared to the case when ownership and the management are not separated.

Proof: This follows directly from the comparison of home and foreign welfares that we have found and those in Collie (1994). In the subgame perfect equilibrium of the trade policy game, when the home government sets its tariff and production subsidy at stage one and the foreign government sets its export subsidy at stage two, the welfares of the home and foreign countries that we found are: 


$$
\begin{aligned}
& W_{1}=\frac{1}{2 b}\left(a-c_{1}\right)^{2}+\frac{3}{4 b}\left(c_{1}-c_{2}\right)^{2} \\
& W_{2}=\frac{3}{4 b}\left(c_{1}-c_{2}\right)^{2}
\end{aligned}
$$

The corresponding values were found in Collie (1994) as:

$$
\begin{aligned}
& W_{1}^{C}=\frac{1}{2 b}\left(a-c_{1}\right)^{2}+\frac{1}{2 b}\left(c_{1}-c_{2}\right)^{2} \\
& W_{2}^{C}=\frac{1}{2 b}\left(c_{1}-c_{2}\right)^{2}
\end{aligned}
$$

Comparing we get $W_{1} \geq W_{1}^{C}$ and $W_{2} \geq W_{2}^{C}$. Q.E.D.

When compared to those of Collie (1994), our results show that both home and foreign welfares are higher. The foreign country is better off since at the unchanged prices and tariff rate the foreign firm can supply more to the domestic market. The home country is better off since its increased imports raise tariff revenues without leading to any change in domestic consumers' surplus or in domestic producer's surplus net of the production subsidy. To see this, notice first that home welfare can be considered as the sum of three separate terms:

(i) the home consumers' surplus derived from the consumption of the good produced in the home and foreign countries,

(ii) the home producer's surplus net of the production subsidy,

(iii) the import tariff revenue of the home country.

The total consumption of the good remains at the same level as in the Collie (1994) model. Thus, the home consumers' surplus does not change. The home producer's surplus net of the production subsidy stays at the same level as in the Collie (1994) model, despite the cut in the domestic production since the price of the good in home country is still equal to the domestic 
marginal cost of production. The import tariff revenue of the home country increases as the imports are higher than in the Collie model while there is no change in the tariff rate. So, the increase in the welfare of the home country (as compared to the results in Collie (1994) paper) arises from the increase in the level of imports. One should note that the separation of the managerial incentives from those of the owners' leads to a lower level of production subsidy, which gives rise to a lower level of production for the domestic firm, and a higher level of production for the foreign firm. As the domestic firm's surplus net of the production subsidy is already zero in an equilibrium with the price level equalling the domestic marginal cost, it is not suprising that the home country becomes better-off if the the share of the imports in the unchanged total domestic consumption increases at the unchanged level of tariff rates.

On the other hand, the welfare of the foreign country can be considered as the foreign firm's surplus (profit) net of the export subsidy. It is obvious that with the unchanged domestic price and the domestic import tariff rate, the welfare of the foreign firm is higher with the increased exports of the foreign country. 


\section{Conclusions}

In this paper strategic trade policy under duopoly is investigated in a multistage game model with endogenous timing of trade policy and when the ownership and management are separated for each firm. At the beginning of the game, stage zero, home and foreign governments independently and simultaneously choose whether to set trade policy at stage one or at stage two. Then, at the chosen stage, each government sets its trade policy to maximize its national welfare.

In the next stage, home and foreign firms choose the (relevant determining parameter of) objective functions of their managers in a Nash play. The objective functions are selected from the class of functions that are convex linear combinations of profits and revenues. Such functions can indeed be rewritten as revised profit functions with the cost of production being now scaled by the weight of the profit term in the managerial objective function. In the last stage, managers in the two countries choose, in Cournot play, the optimal output levels implied by their assigned objective functions. It turns out that the firm in each country has an incentive to give positive weight to the revenue term in its manager's objective function if the manager of the rival country is instructed to maximize its owner's profits. The competition between the firms then forces in equilibrium each firm owner committing their managers to non-profit maximizing behavior.

It is shown that in the subgame perfect equilibrium of the trade policy game, the home government sets its tariff and production subsidy at stage one and the foreign government sets its export subsidy at stage two. By setting trade policy at stage one the home government commits itself to a lower tariff and production subsidy than in the Nash equilibrium of the simultaneousmove game, and this encourages the foreign government to use a larger export subsidy than in the Nash equilibrium of the simultaneous-move game. As a result both countries are better off when 
the home government is the Stackelberg leader than in the simultaneous-move game. The home country benefits from a larger foreign export subsidy, and the foreign country gains from facing a lower tariff and production subsidy. The conclusion for trade policy is that imperfect competition does not provide an economic rationale for countervailing duties since the home country should commit not to use countervailing duties. When compared to those of Collie (1994), our results show that when the ownership and the management are separated for each firm, in the subgame perfect equilibrium of the trade policy game, the welfares of both countries are higher. 


\section{References}

Amihud, Y. and Lev, B. (1981) 'Risk reduction as a managerial motive for conglomerate mergers', Bell Journal of Economics, 12: 605-617.

Bhagwati, J. (1965) 'On the equivalence of tariffs and quotas', in R.E. Baldwin, ed., Trade, Growth, and the Balance of Payments. Amsterdam: North Holland.

Brander, J.A. (1981) 'Intra-industry trade in identical commodities', Journal of International Economics, 11: 1-14.

Brander, J.A. (1986) 'Rationales for strategic trade and industrial policy', in P.R. Krugman, ed., Strategic Trade Policy and the New International Economics. Cambridge, MA: MIT Press.

Brander, J.A. and Krugman P.R. (1983) 'A reciprocal dumping model of international trade', Journal of International Economics, 15: 313-321.

Brander, J.A. and Spencer B.J. (1981) 'Tariffs and the extraction of foreign monopoly rents under potential entry', Canadian Journal of Economics, 14: 371-389.

Brander, J.A. and Spencer B.J. (1983) 'International R\&D rivalry and industrial strategy', Review of Economic Studies, 50: 707-722.

Brander, J.A. and Spencer B.J. (1985) 'Export subsidies and international market share rivalry', Journal of International Economics, 18: 83-100.

Collie, D.R. (1991) 'Export subsidies and countervailing tariffs', Journal of International Economics, 31: 309-324.

Collie, D.R. (1994) 'Endogenous timing in trade policy games: Should governments use countervailing duties?', Weltwirtschaftliches Archiv, 130: 191-209. 
Dixit, A.K. (1984) 'International trade policy for oligopolistic industries', Economic Journal (Supplement), 1-16.

Dixit, A.K. and Grossman, G.M. (1984) 'Targeted export promotion with several oligopolistic industries', discussion paper in economics no. 71, Woodrow Wilson School, Princeton University.

Dixit, A.K. and Kyle, A.S. (1985) 'The use of protection and subsidies for entry promotion and deterrence', American Economic Review, 75: 139-152.

Donaldson, G. and Lorsch, J. (1983) Decision Making at the Top. NewYork: Basic Books.

Eaton, J. and Grossman, G.M. (1986) 'Optimal trade and industrial policy under oligopoly', Quarterly Journal of Economics, 101: 383-406.

Fershtman, C. and Judd, K.L. (1987) 'Equilibrium incentives in oligopoly’, AmericanEconomic Review, 77: 927-940.

Helpman, E. (1981) 'International trade in the presence of product differentiation, economies of scale, and monopolistic competition: A Chamberlinian-Heckscher-Ohlin approach', Journal of International Economics, 11: 305-340.

Helpman, E. and Krugman, P.R. (1989) Trade Policy and Market Structure. Cambridge, MA: MIT Press.

Holmstrom, B. (1979) ‘Moral hazard and observability', Bell Journal of Economics, 10: 74-91.

Jensen, M.J. and Meckling, W.H. (1976) 'Theory of the firm: Managerial behavior, agency costs, and ownership structure', Journal of Financial Economics, 3: 305-360.

Katz, M.L. (1991) 'Game-playing agents: Unobservable contracts as precommitments', Rand Journal of Economics, 22, 307-328. 
Kedia, S. (2002) 'Product market competition and top management incentives', working paper, Harvard University Business School.

Krishna, K. (1984) 'Trade restrictions as facilitating practices', discussion paper in economics no. 55, WoodrowWilson School, Princeton University.

Krugman, P.R. (1979) 'Increasing returns, monopolistic competition, and international trade', Journal of International Economics, 9: 459-479.

Krugman, P.R. (1989) 'Industrial organization and international trade', in R. Schmalensee and R.D. Willig (eds), Handbook of Industrial Organization. Amsterdam: North Holland.

Lancaster, K. (1980) 'Intra-industry trade under perfect monopolistic competition', Journal of International Economics, 10: 151-175.

Schleifer, A. and Vishny, R. (1989) 'Management entrenchment: The case of manager specific investments', Journal of Business, 59: 123-216.

Sklivas, S.D. (1987) 'The strategic choice of managerial incentives', Rand Journal of Economics, 18 (3): $452-458$.

Vickers, J. (1985) 'Delegation and the theory of the firm', Economic Journal (Supplement), 138147. 


\section{Appendix}

Table 1. Comparison of Results in the

Simultaneous-Move Trade Policy Game

\begin{tabular}{|c|c|c|}
\hline & Collie (1994) & Our Model \\
\hline $\mathbf{W}_{1}$ & $\frac{1}{2 b}\left(a-c_{1}\right)^{2}+\frac{4}{9 b}\left(c_{1}-c_{2}\right)^{2}$ & $\frac{1}{2 b}\left(a-c_{1}\right)^{2}+\frac{18}{25 b}\left(c_{1}-c_{2}\right)^{2}$ \\
\hline $\mathbf{W}_{2}$ & $\frac{2}{9 b}\left(c_{1}-c_{2}\right)^{2}$ & $\frac{12}{25 b}\left(c_{1}-c_{2}\right)^{2}$ \\
\hline$\Pi_{1}$ & $\frac{1}{9 b}\left(3 a-5 c_{1}+2 c_{2}\right)^{2}$ & $\frac{1}{50 b}\left(5 a-11 c_{1}+6 c_{2}\right)^{2}$ \\
\hline$\Pi_{2}$ & $\frac{4}{9 b}\left(c_{1}-c_{2}\right)^{2}$ & $\frac{18}{25 b}\left(c_{1}-c_{2}\right)^{2}$ \\
\hline $\mathbf{x}_{1}$ & $\frac{1}{3 b}\left(3 a-5 c_{1}+2 c_{2}\right)$ & $\frac{1}{5 b}\left(5 a-11 c_{1}+6 c_{2}\right)$ \\
\hline $\mathbf{x}_{2}$ & $\frac{2}{3 b}\left(c_{1}-c_{2}\right)$ & $\frac{6}{5 b}\left(c_{1}-c_{2}\right)$ \\
\hline $\mathbf{P}$ & $c_{1}$ & $c_{1}$ \\
\hline $\mathbf{s}$ & $\frac{1}{3}\left(3 a-5 c_{1}+2 c_{2}\right)$ & $\frac{1}{10}\left(5 a-11 c_{1}+6 c_{2}\right)$ \\
\hline $\mathbf{t}$ & $\frac{2}{3}\left(c_{1}-c_{2}\right)$ & $\frac{3}{5}\left(c_{1}-c_{2}\right)$ \\
\hline e & $\frac{1}{3}\left(c_{1}-c_{2}\right)$ & $\frac{1}{5}\left(c_{1}-c_{2}\right)$ \\
\hline
\end{tabular}


Table 2. Comparison of Results in the Stackelberg Game when the Foreign Government is the First Mover

\begin{tabular}{|c|c|c|}
\hline & Collie (1994) & Our Model \\
\hline $\mathbf{W}_{\mathbf{1}}$ & $\frac{1}{2 b}\left(a-c_{1}\right)^{2}+\frac{1}{4 b}\left(c_{1}-c_{2}\right)^{2}$ & $\frac{1}{2 b}\left(a-c_{1}\right)^{2}+\frac{1}{2 b}\left(c_{1}-c_{2}\right)^{2}$ \\
\hline $\mathbf{W}_{\mathbf{2}}$ & $\frac{1}{4 b}\left(c_{1}-c_{2}\right)^{2}$ & $\frac{1}{2 b}\left(c_{1}-c_{2}\right)^{2}$ \\
\hline $\mathbf{\Pi}_{\mathbf{1}}$ & $\frac{1}{6 b}\left(2 a-3 c_{1}+c_{2}\right)^{2}$ & $\frac{1}{2 b}\left(a-2 c_{1}+c_{2}\right)^{2}$ \\
\hline $\mathbf{\Pi}_{\mathbf{2}}$ & $\frac{1}{6 b}\left(c_{1}-c_{2}\right)^{2}$ & $\frac{1}{2 b}\left(c_{1}-c_{2}\right)^{2}$ \\
\hline $\mathbf{x}_{\mathbf{1}}$ & $\frac{1}{3 b}\left(2 a-3 c_{1}+c_{2}\right)$ & $\frac{1}{b}\left(a-2 c_{1}+c_{2}\right)$ \\
\hline $\mathbf{x}_{\mathbf{2}}$ & $\frac{1}{3 b}\left(c_{1}-c_{2}\right)$ & $\frac{1}{b}\left(c_{1}-c_{2}\right)$ \\
\hline $\mathbf{P}$ & $\frac{1}{2}\left(2 a-3 c_{1}+c_{2}\right)$ & $c_{1}$ \\
\hline $\mathbf{s}$ & $\frac{1}{2}\left(c_{1}-c_{2}\right)$ & $\frac{1}{2}\left(a-2 c_{1}+c_{2}\right)$ \\
\hline $\mathbf{t}$ & 0 & $\frac{1}{2}\left(c_{1}-c_{2}\right)$ \\
\hline $\mathbf{e}$ & $c_{1}$ & 0 \\
\hline
\end{tabular}


Table 3. Comparison of Results in the Stackelberg Game when the Home Government is the First Mover

\begin{tabular}{|c|c|c|}
\hline & Collie (1994) & Our Model \\
\hline $\mathbf{W}_{\mathbf{1}}$ & $\frac{1}{2 b}\left(a-c_{1}\right)^{2}+\frac{1}{2 b}\left(c_{1}-c_{2}\right)^{2}$ & $\frac{1}{2 b}\left(a-c_{1}\right)^{2}+\frac{3}{4 b}\left(c_{1}-c_{2}\right)^{2}$ \\
\hline $\mathbf{W}_{\mathbf{2}}$ & $\frac{1}{2 b}\left(c_{1}-c_{2}\right)^{2}$ & $\frac{3}{4 b}\left(c_{1}-c_{2}\right)^{2}$ \\
\hline $\mathbf{\Pi}_{\mathbf{1}}$ & $\frac{1}{b}\left(a-2 c_{1}+c_{2}\right)^{2}$ & $\frac{1}{8 b}\left(2 a-5 c_{1}+3 c_{2}\right)^{2}$ \\
\hline $\mathbf{\Pi}_{\mathbf{2}}$ & $\frac{1}{b}\left(c_{1}-c_{2}\right)^{2}$ & $\frac{9}{8 b}\left(c_{1}-c_{2}\right)^{2}$ \\
\hline $\mathbf{x}_{\mathbf{1}}$ & $\frac{1}{b}\left(a-2 c_{1}+c_{2}\right)$ & $\frac{1}{2 b}\left(2 a-5 c_{1}+3 c_{2}\right)$ \\
\hline $\mathbf{x}_{\mathbf{2}}$ & $\frac{1}{b}\left(c_{1}-c_{2}\right)$ & $\frac{3}{2 b}\left(c_{1}-c_{2}\right)$ \\
\hline $\mathbf{P}$ & $\frac{1}{2}\left(c_{1}-c_{2}\right)$ & $c_{1}$ \\
\hline $\mathbf{s}$ & $\frac{1}{2}\left(c_{1}-c_{2}\right)$ & $\frac{1}{4}\left(2 a-5 c_{1}+3 c_{2}\right)$ \\
\hline $\mathbf{t}$ & $a-2 c_{1}+c_{2}$ & $\frac{1}{2}\left(c_{1}-c_{2}\right)$ \\
\hline $\mathbf{P}$ & $\left.c_{1}-c_{2}\right)$ \\
\hline
\end{tabular}

Table 4. Payoff Matrix for Trade Policy Game

\begin{tabular}{|c|l|c|}
\hline & \multicolumn{2}{|c|}{ Foreign Government } \\
\hline Domestic Government & Stage One & Stage Two \\
\hline Stage One & $W_{1}^{S}, W_{2}^{S}$ & $W_{1}^{H}, W_{2}^{H}$ \\
\hline Stage Two & $W_{1}^{F}, W_{2}^{F}$ & $W_{1}^{S}, W_{2}^{S}$ \\
\hline
\end{tabular}




\subsection{Stage 2: Owners choose their managers' incentives}

$$
\begin{aligned}
& \Pi_{1}\left(x_{1}, x_{2}\right)=\left(P-c_{1}+s\right) x_{1} \\
& \frac{\partial}{\partial \lambda_{1}}\left[\left\{P(.)-c_{1}+s\right\} x_{1}\left(\lambda_{1}, \lambda_{2}\right)\right]=0 \\
& \Rightarrow \frac{1}{3} c_{1} x_{1}+\left(P-c_{1}+s\right) \frac{\partial x_{1}}{\partial \lambda_{1}}=0 \\
& \Rightarrow \frac{1}{3} c_{1} x_{1}+\left(P-c_{1}+s\right)\left(\frac{-2 c_{1}}{3 b}\right)=0 \\
& \Rightarrow b x_{1}-2\left(P-c_{1}+s\right)=0
\end{aligned}
$$

$$
\begin{aligned}
& \Pi_{2}\left(x_{1}, x_{2}\right)=\left(P-c_{2}-\mathrm{t}+e\right) x_{2} \\
& \frac{\partial}{\partial \lambda_{2}}\left[\left\{P(.)-c_{2}-t+e\right\} x_{2}\left(\lambda_{1}, \lambda_{2}\right)\right]=0 \\
& \Rightarrow \frac{1}{3} c_{2} x_{2}+\left(P-c_{2}-t+e\right) \frac{\partial x_{2}}{\partial \lambda_{2}}=0 \\
& \Rightarrow \frac{1}{3} c_{2} x_{2}+\left(P-c_{2}-t+e\right)\left(\frac{-2 c_{2}}{3 b}\right)=0 \\
& \Rightarrow b x_{2}-2\left(P-c_{2}-\mathrm{t}+e\right)=0
\end{aligned}
$$

\subsection{Stage 1: Governments choose their trade policies}

$$
\begin{gathered}
W_{1}=\int_{0}^{x_{1}^{8}+x_{2}^{8}}(a-b Q) d Q-P\left(x_{1}^{*}+x_{2}^{*}\right)+\left(P-c_{1}\right) x_{1}^{*}+s x_{1}^{*}+t x_{2}^{*}-s x_{1}^{*} \\
\uparrow
\end{gathered}
$$

$C S$ : Consumer Surplus, PS: Producer Surplus, GR: Government Revenue 


$$
\begin{aligned}
& W_{1}=a\left(x_{1}^{*}+x_{2}^{*}\right)-\frac{b}{2}\left(x_{1}^{*}+x_{2}^{*}\right)^{2}-\left(a-b\left(x_{1}^{*}+x_{2}^{*}\right)\right)\left(x_{1}^{*}+x_{2}^{*}\right)+\left(a-b\left(x_{1}^{*}+x_{2}^{*}\right)-c_{1}\right) x_{1}^{*}+t x_{2}^{*} \\
& \Rightarrow W_{1}=\frac{b}{2}\left(x_{1}^{*}+x_{2}^{*}\right)^{2}+\left(a-b\left(x_{1}^{*}+x_{2}^{*}\right)-c_{1}\right) x_{1}^{*}+t x_{2}^{*}
\end{aligned}
$$

\subsubsection{Simultaneous-Move Trade Policy Game:}

$$
\begin{aligned}
& \frac{\partial W_{1}}{\partial t}=b\left(x_{1}^{*}+x_{2}^{*}\right) \frac{\partial}{\partial t}\left(x_{1}^{*}+x_{2}^{*}\right)+\left(a-b\left(x_{1}^{*}+x_{2}^{*}\right)-c_{1}\right) \frac{\partial x_{1}^{*}}{\partial t}-b\left(\frac{\partial}{\partial t}\left(x_{1}^{*}+x_{2}^{*}\right)\right) x_{1}^{*}+t \frac{\partial x_{2}^{*}}{\partial t}+x_{2}^{*}=0 \\
& \frac{\partial W_{1}}{\partial t}=b\left(x_{1}^{*}+x_{2}^{*}\right) \frac{-2}{5 b}+\left(a-b\left(x_{1}^{*}+x_{2}^{*}\right)-c_{1}\right) \frac{4}{5 b}-b \frac{-2}{5 b} x_{1}^{*}-t \frac{6}{5 b}+x_{2}^{*}=0 \\
& \Rightarrow-2 b\left(x_{1}^{*}+x_{2}^{*}\right)+4\left(P-c_{1}\right)+2 b x_{1}^{*}-6 t+5 b x_{2}^{*}=0 \\
& \frac{\partial W_{1}}{\partial s}=b\left(x_{1}^{*}+x_{2}^{*}\right) \frac{\partial}{\partial s}\left(x_{1}^{*}+x_{2}^{*}\right)+\left(a-b\left(x_{1}^{*}+x_{2}^{*}\right)-c_{1}\right) \frac{\partial x_{1}^{*}}{\partial s}-b\left(\frac{\partial}{\partial s}\left(x_{1}^{*}+x_{2}^{*}\right)\right) x_{1}^{*}+t \frac{\partial x_{2}^{*}}{\partial s}=0 \\
& \frac{\partial W_{1}}{\partial s}=b\left(x_{1}^{*}+x_{2}^{*}\right) \frac{2}{5 b}+\left(a-b\left(x_{1}^{*}+x_{2}^{*}\right)-c_{1}\right) \frac{6}{5 b}-b \frac{2}{5 b} x_{1}^{*}-t \frac{4}{5 b}=0 \\
& \Rightarrow b\left(x_{1}^{*}+x_{2}^{*}\right)+3\left(P-c_{1}\right)-b x_{1}^{*}-2 t=0 \\
& \frac{\partial W_{2}}{\partial e}=\left(a-b\left(x_{1}^{*}+x_{2}^{*}\right)-c_{2}-t\right) \frac{6}{5 b}-b \frac{2}{5 b} x_{2}^{*}=0 \\
& \frac{\partial e}{3}=\left(a-b\left(x_{1}^{*}+x_{2}^{*}\right)-c_{2}-t\right) \frac{\partial x_{2}^{*}}{\partial e}-b\left(\frac{\partial}{\partial e}\left(x_{1}^{*}+x_{2}^{*}\right)\right) x_{2}^{*}=0 \\
& \left.\frac{\partial}{2}-t\right)-b x_{2}^{*}=0
\end{aligned}
$$


To show that $\lambda_{1}<1$ and $\lambda_{2}<1$, we know that $x_{1}^{S}>0$ and $x_{2}^{S}>0$ by the assumption that there is an interior solution where the market is supplied by both domestic production and imports.

$$
\begin{gathered}
x_{1}^{S}>0 \Rightarrow 5 a-11 c_{1}+6 c_{2}>0 \\
\Rightarrow-5 a<-11 c_{1}+6 c_{2}
\end{gathered}
$$

Then, $\lambda_{1}=\frac{1}{10} \frac{-5 a+21 c_{1}-6 c_{2}}{c_{1}}<\frac{1}{10} \frac{-11 c_{1}+6 c_{2}+21 c_{1}-6 c_{2}}{c_{1}}=1$, i.e. $\lambda_{1}<1$

Similarly, $x_{2}^{S}>0 \Rightarrow c_{1}-c_{2}>0$, i.e. $c_{1}>c_{2}$

Then, $\lambda_{2}=-\frac{1}{5} \frac{3 c_{1}-8 c_{2}}{c_{2}}<-\frac{1}{5} \frac{3 c_{2}-8 c_{2}}{c_{2}}=1$, i.e. $\lambda_{2}<1$

\subsubsection{Stackelberg Game when the Foreign Government is the First Mover:}

$$
\begin{aligned}
& \frac{\partial W_{1}}{\partial t}=b\left(x_{1}^{*}+x_{2}^{*}\right) \frac{\partial}{\partial t}\left(x_{1}^{*}+x_{2}^{*}\right)+\left(a-b\left(x_{1}^{*}+x_{2}^{*}\right)-c_{1}\right) \frac{\partial x_{1}^{*}}{\partial t}-b\left(\frac{\partial}{\partial t}\left(x_{1}^{*}+x_{2}^{*}\right)\right) x_{1}^{*}+t \frac{\partial x_{2}^{*}}{\partial t}+x_{2}^{*}=0 \\
& \frac{\partial W_{1}}{\partial t}=b\left(x_{1}^{*}+x_{2}^{*}\right) \frac{-2}{5 b}+\left(a-b\left(x_{1}^{*}+x_{2}^{*}\right)-c_{1}\right) \frac{4}{5 b}-b \frac{-2}{5 b} x_{1}^{*}-t \frac{6}{5 b}+x_{2}^{*}=0 \\
& \Rightarrow-2 b\left(x_{1}^{*}+x_{2}^{*}\right)+4\left(P-c_{1}\right)+2 b x_{1}^{*}-6 t+5 b x_{2}^{*}=0 \\
& \frac{\partial W_{1}}{\partial s}=b\left(x_{1}^{*}+x_{2}^{*}\right) \frac{\partial}{\partial s}\left(x_{1}^{*}+x_{2}^{*}\right)+\left(a-b\left(x_{1}^{*}+x_{2}^{*}\right)-c_{1}\right) \frac{\partial x_{1}^{*}}{\partial s}-b\left(\frac{\partial}{\partial s}\left(x_{1}^{*}+x_{2}^{*}\right)\right) x_{1}^{*}+t \frac{\partial x_{2}^{*}}{\partial s}=0 \\
& \frac{\partial W_{1}}{\partial s}=b\left(x_{1}^{*}+x_{2}^{*}\right) \frac{2}{5 b}+\left(a-b\left(x_{1}^{*}+x_{2}^{*}\right)-c_{1}\right) \frac{6}{5 b}-b \frac{2}{5 b} x_{1}^{*}-t \frac{4}{5 b}=0 \\
& \Rightarrow b\left(x_{1}^{*}+x_{2}^{*}\right)+3\left(P-c_{1}\right)-b x_{1}^{*}-2 t=0
\end{aligned}
$$


To show that $\lambda_{1}<1$ and $\lambda_{2}<1$, we know that $x_{1}^{S}>0$ and $x_{2}^{S}>0$ by the assumption that there is an interior solution where the market is supplied by both domestic production and imports.

$$
\begin{aligned}
x_{1}^{F}>0 & \Rightarrow a-2 c_{1}+c_{2}>0 \\
& \Rightarrow-a-c_{2}<-2 c_{1}
\end{aligned}
$$

Then, $\lambda_{1}=\frac{1}{2} \frac{-a+4 c_{1}-c_{2}}{c_{1}}<\frac{1}{2} \frac{4 c_{1}-2 c_{1}}{c_{1}}=1$, i.e. $\lambda_{1}<1$

Similarly, $x_{2}^{F}>0 \Rightarrow c_{1}-c_{2}>0$, i.e. $c_{1}>c_{2}$

Then, $\lambda_{2}=-\frac{1}{2} \frac{c_{1}-3 c_{2}}{c_{2}}<-\frac{1}{2} \frac{c_{2}-3 c_{2}}{c_{2}}=1$, i.e. $\lambda_{2}<1$

\subsubsection{Stackelberg Game when the Home Government is the First Mover:}

$$
\begin{aligned}
& \frac{\partial W_{2}}{\partial e}=\left(a-b\left(x_{1}^{*}+x_{2}^{*}\right)-c_{2}-t\right) \frac{\partial x_{2}^{*}}{\partial e}-b\left(\frac{\partial}{\partial e}\left(x_{1}^{*}+x_{2}^{*}\right)\right) x_{2}^{*}=0 \\
& \frac{\partial W_{2}}{\partial e}=\left(a-b\left(x_{1}^{*}+x_{2}^{*}\right)-c_{2}-t\right) \frac{6}{5 b}-b \frac{2}{5 b} x_{2}^{*}=0 \\
& \Rightarrow 3\left(P-c_{2}-t\right)-b x_{2}^{*}=0
\end{aligned}
$$

To show that $\lambda_{1}<1$ and $\lambda_{2}<1$, we know that $x_{1}^{S}>0$ and $x_{2}^{S}>0$ by the assumption that there is an interior solution where the market is supplied by both domestic production and imports.

$$
x_{1}^{H}>0 \Rightarrow 2 a-5 c_{1}+3 c_{2}>0 \Rightarrow-2 a-3 c_{2}<-5 c_{1}
$$


Then, $\lambda_{1}=\frac{1}{4} \frac{-2 a+9 c_{1}-3 c_{2}}{c_{1}}<\frac{1}{4} \frac{-5 c_{1}+9 c_{1}}{c_{1}}=1$, i.e. $\lambda_{1}<1$

Similarly, $x_{2}^{H}>0 \Rightarrow c_{1}-c_{2}>0$, i.e. $c_{1}>c_{2}$

Then, $\lambda_{2}=-\frac{1}{4} \frac{3 c_{1}-7 c_{2}}{c_{2}}<-\frac{1}{4} \frac{3 c_{2}-7 c_{2}}{c_{2}}=1$, i.e. $\lambda_{2}<1$ 


\section{Chapter 3. Income Convergence \& Intra-Industry Trade}

\section{Introduction}

The subject of convergence of economic growth is one of the most important issues in modern economics. In a world in which countries exchange goods, factors, and ideas; international linkages are what drive any convergence process. Free trade in goods can equalize factor prices across countries according to the factor-price-equalization theorem; international flows of factors can lead to convergence of endowments and factor prices; and international flows of technology can cause convergence of factor prices as well.

In neoclassical growth models a country's per capita growth rate tends to be inversely related to its starting level of per capita income. In particular, if countries are similar with respect to structural parameters for preferences and technology, then poor countries tend to grow faster than rich countries. That is, it is a prediction of neoclassical economic growth theory that differences in per capita income across different economies will tend to decrease or disappear over time. This is broadly referred to as the convergence hypothesis.

Though there is evidence of income convergence among some of the wealthy countries (Baumol, 1986; Baumol et al., 1989), it is not obvious why some subsets of these countries exhibit greater convergence than others, while other subsets of countries display no convergence tendencies at all. This paper analyzes this issue from the perspective of trade's contribution to the process. It examines the relationship between international trade and income convergence among countries by focusing on groups of countries forming major trade partners. 
In analyzing the factors that determine the extent of intra-industry trade in an inter-country context, Linder (1961) advanced the hypothesis that the extent of trade in differentiated products will be the greater, the more similar are income levels among the trading countries. This hypothesis reflects the assumption that similarities in income levels are associated with similarities in demand structures. The results of our paper are not sufficient to differentiate between the hypothesis that countries that trade a great deal with one another tend to converge, and the alternative hypothesis that similar countries tend to trade more. However, an analysis of the relationship between trade liberalization and income convergence (Ben-David, 1993, 1994a) suggests that it is trade liberalization that produces income convergence, rather than the other way around. Although no intra-group income convergence was evident before the trade reforms, significant convergence, together with significant increases in the volume of trade, began to occur simultaneously with the removal of the trade barriers. These findings provide evidence that it is the removal of obstacles to trade which leads to income convergence, rather than just the similarity suggested by the Linder hypothesis.

There is an extensive literature about the extent of income convergence among countries. This literature, however, is mostly based on models that determine the existence and magnitude of convergence through the common cross-country growth regressions. The primary methodology used to test for the existence of convergence in these studies was to regress growth rates on initial levels of income plus the additional factors that one wished to control for. A negative relationship between the rates of growth and the initial incomes was interpreted as implying convergence. In our paper, however, convergence will be characterized by the reduction in income differentials within specific groups of countries over time. 
Another difference between this paper and the earlier papers will be that the primary focus here is on intra-industry trade's relationship to the convergence process. Trade groups are formed on the basis of intra-industry trade among countries rather than only exports or imports. No attempt is made to analyze and extend the theoretical motivations behind the relationship between intra-industry trade and income convergence. The contribution of this paper is by empirically noting the existence of such a link. The results from this paper alone are not sufficient to distinguish between the hypothesis that countries which (intra-industry) trade a great deal with one another tend to converge, and the alternative hypothesis that similar countries tend to trade more. $^{15}$

The analysis includes the 1971-2002 income and trade data of 24 developed countries ${ }^{16}$ with per capita incomes of $\$ 10,000$ or higher in 2002. The first step is to determine each country's primary trade partners and to create trade groups using the intra-industry trade shares of the total trade between countries. Having formed the trade groups, the behavior of each group's income differentials over time is examined for a significant evidence of convergence within them. The results show that majority of these intra-industry trade-based groups exhibit significant convergence. When the trade groups are formed according to the total trade between the countries rather than intra-industry trade, we see a significant decrease in the number of the groups which exhibit income convergence.

\footnotetext{
${ }^{15}$ Ben-David (1993) and Ben-David (1994a) suggest that it is the trade which causes the countries to converge in income, rather than the other way around.

${ }^{16}$ Australia, Austria, Belgium, Canada, Denmark, Finland, France, Germany, Greece, Iceland, Ireland, Israel, Italy, Japan, Luxembourg, the Netherlands, New Zealand, Norway, Portugal, Spain, Sweden, Switzerland, United Kingdom, and the United States of America.
} 
Then, the robustness and sensitivity of the results are examined from a number of different perspectives. To test whether any random grouping of these same countries might produce similar results, the 24 source countries are grouped into their many different possible subgroups and their convergence coefficients are estimated. To test whether convergence within groups might be towards one country that is common to most of the groups, the major trade partner of the countries is removed from each of the groups, the new convergence coefficients are estimated, and the results are compared. To test whether the tendency towards convergence is considerably stronger when the basis for constructing groups is trade rather than proximity or common language, the countries are regrouped to reflect geographical closeness or common languages; and the degree of convergence within each of these groups are then compared to the results of the trade-based groups.

The results show that significant income convergence is not a common outcome among countries when they are grouped randomly instead of grouping them according to their trade partners; the convergence within groups is not towards one country that is common to most of the groups, but is instead an outcome that tends to be relatively robust to the exclusion of the major trade partners that are members in most of the groups; and the tendency towards convergence appears to be considerably stronger when the basis for constructing groups is trade rather than proximity or common language. 


\section{Literature Review}

\subsection{Income Convergence}

Over the past years, there has been an ongoing debate as to whether the per capita incomes of different national economies will converge. This debate has its roots in Heckscher (1919) and Ohlin (1933) who hypothesized that free trade will draw factor prices towards equality. This was later formalized by Samuelson (1948) as the factor price equalization theorem which provides theoretical support for the idea that, under certain conditions, trade should lead to the equalization of commodity prices and consequently to the equalization of factor prices. Alternatively, the traditional growth literature (Solow, 1956; Cass, 1965) claims that, even in the absence of internationally mobile goods and factors, convergence to a steady state path should occur between countries provided that they have identical production technologies, population growth, and saving rates. ${ }^{17}$

The convergence debate has been largely empirical, focusing primarily on the validity of the following three competing hypotheses:

(i) The absolute convergence hypothesis - per capita incomes of countries converge to one another in the long-run independently of their initial conditions. ${ }^{18}$

(ii) The conditional convergence hypothesis - per capita incomes of countries that are identical in their structural characteristics (e.g. preferences, technologies, rates of population growth, government policies, etc.) converge to one another in the long-run independently of their initial conditions. $^{19}$

\footnotetext{
${ }^{17}$ For a comprehensive survey of convergence and growth literature, see Sala-i Martin (1996), De la Fuente (1997), and Temple (1999).

${ }^{18}$ See Romer (1986), Lucas (1988), and Barro (1991) for conclusive evidence against this hypothesis.
} 
(iii) The club convergence hypothesis - per capita incomes of countries that are identical in their structural characteristics converge to one another in the long-run provided that their initial conditions are similar as well. ${ }^{20}$

The primary methodology used to test for the existence of convergence in several studies $^{21}$ was to regress growth rates on initial levels of income plus the additional factors that one wished to control for. A negative relationship between the rates of growth and the initial incomes was interpreted as implying convergence. Instead of taking a negative correlation between the initial output level of one economy and its subsequent growth rate as evidence of convergence, the time series convergence tests investigate for the differences in per capita output to decrease over time. Bernard and Durlauf (1995) found that cross-sectional convergence is a weaker notion than the time series notion of convergence. Cross-sectional tests tend to falsely reject the null of no convergence when economies exhibit multiple long-run steady states.

By grouping countries into three income groups, Baumol (1986) found wealthy countries belong to a convergence club, middle-income countries are moderately converging, and poor countries are diverging over time. He argued that the public good property of national productivity growth gives rise to convergence among industrialized nations; however, the lessdeveloped countries are unable to converge because of the lack of technology and education. Kristensen (1982) grouped countries by their income levels and also found convergence among the wealthier countries and divergence among poorer countries.

\footnotetext{
${ }^{19}$ See Barro (1991), Mankiw et al. (1992), and Barro and Sala-i Martin (1995) for supporting cross-country evidence for the conditional convergence hypothesis.

${ }^{20}$ See Durlauf and Johnson (1995) and Quah (1996) for supporting evidence for the club convergence hypothesis.

${ }^{21}$ Romer (1986), Lucas (1988), Barro (1991), Levine and Renelt (1992), and Mankiw et al. (1992).
} 
Ben-David (1994b) applied the time series notion of convergence and he showed that, in contrast to the conventional wisdom, convergence among the relatively developed countries is far from being a robust phenomenon. Some countries converge with others, but not with the remainder. Other countries converge with different countries, but also not with most. A random grouping of the more developed countries will not yield income convergence in more instances than it will yield non-convergence.

\subsection{Intra-Industry Trade}

Traditional theories of international trade have not been extended to incorporate product differentiation, economies of scale, and monopolistic competition; only in the last two decades we have seen the emergence of a sizeable literature that links trade theory and industrial organization, beginning with the studies of Krugman (1979) and Lancaster (1979). It was further extended by Krugman (1981), Helpman (1981), Ethier (1982), and others ${ }^{22}$.

One group of models that has emerged through the synthesis of international economics and industrial organization includes the models of intra-industry trade. Intra-industry trade models provide an explanation for the simultaneous export and import of fairly similar goods. In these models countries' markets are characterized by imperfect competition involving differentiated products and increasing returns to scale. The opening of trade results in a greater product variety and an increased competition with a consequent reduction in costs and prices.

In their pioneering study which fundamentally changed the way economists view the causes of international trade, Grubel and Lloyd (1975) established the extent of intra-industry trade in different industrial nations, considered some measurement issues, and investigated

\footnotetext{
${ }^{22}$ For a survey of the theoretical literature of intra-industry trade, see Bhagwati and Davis (1994).
} 
possible causes and consequences of such trade. To point out this fundamental change, Helpman and Krugman (1989) refer to intra-industry trade as "one of the key empirical reasons for emphasizing the role of increasing returns and imperfect competition in the world economy" (Helpman and Krugman , 1989: p.133).

Since the introduction of the concept of intra-industry trade, a large literature developed on the subject. Early efforts at the measurement of the extent of intra-industry trade were followed by contributions to the theory of intra-industry trade. Furthermore, many studies have attempted to identify the determinants of intra-industry trade. They have considerable differences in model specification, estimation techniques, and the level of industry aggregation ${ }^{23}$.

Empirical studies on the intra-industry trade of the developing countries remained an underresearched area for a long time, but increasing attention has been paid to this area in recent years ${ }^{24}$. Most previous econometric studies have attempted to explain the intra-industry trade of developed countries ${ }^{25}$. This may be partly because of the belief that the phenomenon of intraindustry trade is significant only among industrialized countries.

\footnotetext{
${ }^{23}$ For a comprehensive survey of the empirical literature, see Greenaway and Milner (1986).

${ }^{24}$ Three such studies (Laird, 1981; Lee, 1987; and Gunasekera, 1989) are general reviews. Some other papers include Havrylyshyn and Civan, 1983; Tharakan, 1986; Ray, 1991; and Fukasaku, 1992.

${ }^{25}$ Caves (1981), Toh (1982), and Balassa (1986) use the data for the U.S.; Lundberg (1982) for Sweden; Greenaway (1983) for the U.K.; Kol and Mennes (1989) for the Netherlands; Tharakan (1986) for Benelux; and Loertscher and Wolter (1980) for the OECD countries.
} 


\subsection{Trade and Income Convergence}

The increase in growth-related research in the past decades has included important contributions that have focused on the relationship connecting international trade to economic growth and convergence. However, neither traditional trade theory nor the various well known models of economic growth offer very formal results that explain the possible connection between international trade and income convergence across countries over time. Trade policy directly affects the flows of goods and services between different countries, and liberalization of trade leads to the convergence of factor prices in those countries - at least under the conditions associated with the factor price equalization theorem (Samuelson, 1948). But convergence in factor prices does not necessarily imply convergence in incomes. Moreover, even if trade liberalization and income convergence are found to co-exist, this does not establish any causal relationship between the two, and it does not mean that other variables are unimportant to the convergence process.

The recent trade literature offers some theoretical models that deal with the linkages between income convergence and trade. For example, addressing trade liberalization, Ben-David and Loewy (1996) present a model that focuses on the role of trade in facilitating knowledge spillovers, which subsequently can effect positively on income convergence. In related work, Ben-David and Loewy (2000) develop an open economy endogenous growth model that incorporates knowledge accumulation. Their model predicts that while trade liberalization will increase the steady-state output growths of all countries, those countries that participate directly in this liberalization will benefit the most in terms of their relative income levels.

Slaughter (1997) discusses the ways in which trade may be associated with income convergence. He notes that trade can make the transfer of technology between economies easier, 
which will change the countries' factor prices. For this to result in changes in per capita output, he points out that situations must be avoided in which factor endowments are diverging sufficiently to offset the technology transfer effects. He also states that trade in capital goods can lead to convergence in per capita income by changing countries' relative factor endowments.

The empirical literature has added considerably to our understanding of the relationship between international trade and income convergence through the analyses of various sets of data. Within this literature we find a number of definitions of convergence, applications of different statistical tools, and the emergence of a wide variety of results. The conclusions that one reaches depend generally on the type of data, the time-period in question, and the level of development of the economies under consideration. The existing evidence on trade and international income differences is mixed. There is some evidence for that trade causes convergence and other evidence for that it causes divergence.

Using several criteria, Sachs and Warner (1995) classify each country in 1970 as either “open" or "closed" to international trade. From 1970 to 1989 only in the group of open countries, the poorer countries in 1970 have grown faster over the next 19 years. They conclude that "the open economies display a strong tendency towards economic convergence... the convergence club is the club of economies linked together by international trade" (Sachs and Warner, 1995: p.41).

Ben-David (1996) finds that from 1960 to 1989, groups of relatively wealthy countries which trade significantly among each other tend to display significant per capita income convergence relative to the convergence patterns of randomly grouped countries. He concludes that "these findings would appear to support the intuition of Heckscher and Ohlin that trade does indeed play an equalizing role" (Ben-David, 1996: p.294). 
Ben-David (1993) analyzes post-1945 trade liberalization and finds that per capita income dispersion among liberalizing countries decreased after liberalization started. He writes that "this paper provides evidence that movement toward free trade may actually... be leading to a reduction in income disparity across countries... The factor price equalization theorem provides a framework for relating trade's impact on income convergence" (Ben-David, 1993: p.653).

Dollar (1992), Edwards (1993), Harrison (1995), and Henrekson et al. (1996) focus on the impact of trade openness on economic growth. The results from these studies indicate that there is a positive relationship between trade liberalization and per capita income convergence.

On the other hand, Bernard and Jones (1996) conclude that freer trade actually diverges incomes across countries. They use cross-section and time series techniques to study the movements of productivity levels in 14 OECD countries during 1970-1987. They examine technological convergence by focusing on total factor productivity. The results indicate that sectoral differences are important for understanding movements in aggregate income and productivity. Within sectors across countries there is evidence for convergence for some industries, but not for others. These differences across sectors account for convergence at the national level. Within manufacturing, they find only weak evidence for convergence over the period and find substantial evidence for divergence of productivity levels during the 1980s. Using a "difference in differences" methodology developed by Meyer (1994), Slaughter (2001) finds that various post-1945 trade liberalization appears to have led to income divergence, rather than convergence. Trade-mediated technology flows change countries' real factor prices and thus per capita income. If technology does not flow from advanced to less-advanced countries, then freer trade need not converge incomes across countries. Richer countries grow even richer because they focus more on the high-technology products. 


\section{Data and Methodology}

\subsection{Data}

The 1971-2002 income and trade data of 24 developed countries ${ }^{26}$ are included in the analysis with per capita incomes of $\$ 10,000$ or higher in 2002 . In the order of decreasing per capita GNP, these countries are Luxembourg, Norway, USA, Switzerland, Japan, Denmark, Ireland, Iceland, United Kingdom, Netherlands, Sweden, Finland, Austria, Canada, Germany, Belgium, France, Australia, Italy, Israel, Spain, New Zealand, Portugal, and Greece. The trade statistics are taken from World Trade Annuals of the United Nations Statistics Division. GNP data are from the International Financial Statistics.

The investigation covers Section 7 of the Standard International Trade Classification (SITC) industry groups, i.e. "Machinery and Transport Equipment". This section includes technological goods which involve production technologies that are not universally available and change relatively frequently. For most industrialized countries, it has been known that intraindustry trade occurs in these SITC industry groups. These include those industries which share the typical characteristics of industries involved in intra-industry trade, such as product differentiation, economies of scale, and rapid innovation. Some industry groups in Section 7 include engines, turbines, motors, power generating machinery, tractors, textile and leather machinery, printing machinery, heating-cooling equipment, non-electrical machinery, office machines, television receivers, radio broadcast receivers, telecom equipment, transistors, road motor vehicles, railway vehicles, aircraft, and ships.

\footnotetext{
${ }^{26}$ The 24 developed countries in this study are OECD countries. We can extend our study by adding other developed countries and/or developing countries.
} 


\subsection{Grubel-Lloyd Index and Aggregation Problem}

The Grubel-Lloyd (hereafter, GL) index is the central measure of intra-industry trade and almost all of the empirical studies have used this index; so in this paper, this measure is employed, which is expressed as

$$
I I T_{i}=\left[1-\left(\left|X_{i}-M_{i}\right| /\left(X_{i}+M_{i}\right)\right)\right]
$$

where $X_{i}$ is exports of industry $i, M_{i}$ is imports of industry $i,\left|X_{i}-M_{i}\right|$ is net trade, $\left(X_{i}+M_{i}\right)$ is total trade, and $0 \leq I I T_{i} \leq 1$. An index value of 0 would indicate complete inter-industry trade. Either the value of exports or imports would be zero. Higher index values are associated with greater intra-industry trade as a proportion of total trade, with an index value of 1 indicating equality between exports and imports. We will use this measure just to create trade groups as explained in the next subsection.

When Eq. (1) is aggregated across industries to form a weighted average intra-industry trade measure, the resulting index will not attain the desired maximum value of 1 if the country's total commodity trade is imbalanced. The greater is the imbalance, the smaller will be the share of intra-industry trade. Based on this finding, GL (1975) argue that this measure of intra-industry trade must be adjusted for the aggregate trade imbalance.

According to Vona (1991), and Kol and Mennes (1989), measures of intra-industry trade should not be corrected for the overall trade imbalance. Vona (1991) argues that the argument for the need of correction is theoretically poor and leads to unreliable adjustment procedure and he uses arithmetic examples to establish the superiority of GL's uncorrected index over corrected 
indices which appear in the literature. Based on these, this paper will use GL's uncorrected measure of intra-industry trade ${ }^{27}$.

\subsection{Creation of the Trade Groups}

The first step is to define who is a major trade partner of whom and how should the trade groups be formed. The usual practice in analyzing the effect of trade on the growth process is to combine imports and exports and examine their joint effect. In this paper, the primary focus is on intraindustry trade's relationship to the convergence process. Trade groups are formed on the basis of intra-industry trade among countries rather than only exports or imports. For each of the 24 source countries, major intra-industry trade partners are found to form each source country's trade groups. To keep the examination within manageable proportions, the goal is to implement some general criterion that limits the size of the trade groups to fewer than ten countries. The composition of the intra-industry trade groups is determined according to the following criterion. Suppose that country $i$ is one of the 24 source countries. After finding the Grubel-Lloyd intraindustry trade indices, if the intra-industry trade share of the total trade between country $i$ and country $j$ is more than $85 \%$ in 2002 (the final year of the sample) ${ }^{28}$, then country $j$ will be part of country $i$ 's trade group. The groups resulting from the $85 \%$ threshold ranged in size from 3 countries per group to 8 countries per group. Table 1 in the Appendix lists the countries forming each of the trade groups.

\footnotetext{
${ }^{27}$ Ballance et al. (1992), Lundberg (1992), Hamilton and Kniest (1991), and Globerman and Dean (1990) are examples of recent studies that do not correct intra-industry trade indices for the overall trade imbalance. Bergstrand (1990) uses the GL adjusted index. The methodology and rationale for the adjustment is discussed in Bergstrand (1983).

${ }^{28}$ Creating trade groups based on end-of-period (i.e. 2002) trade data is in order to create groups of countries that have evolved over time into major trade partners, hence increasing the likelihood of finding convergence. If the grouping criterion had been based on beginning-of-period (i.e. 1971) data, it might have included countries that were no longer major trade partners by the period's end.
} 


\section{The Model}

\subsection{Income Convergence Model}

Having formed the trade groups, the behavior of each group's income differentials over time is examined for a significant evidence of convergence within them. Following Ben-David (1996), the convergence measure is based on the following relationship:

$$
\left(y_{i, t}-\bar{y}_{t}\right)=\Phi\left(y_{i, t-1}-\bar{y}_{t-1}\right)+\varepsilon_{i, t}
$$

where $y_{i, t}$ is the $\log$ of country $i$ 's real per capita income at time $t$ and $\bar{y}_{t}$ is the average ${ }^{29}$ of the group's log per capita incomes at time $t . \Phi<1$ indicates the existence of income convergence within the group and $\Phi>1$ indicates divergence. The estimated $\Phi$ provides an indication of the rate of convergence within the given group. The half-life $\mathrm{e}^{30}(h)$ of the convergence process, the number of years that it takes for the income gap to be cut in half is given by $\ln (0.5) / \ln (\Phi)$.

The countries within each group are pooled together for the estimation of Eq. (2) and the convergence coefficient $\Phi$ is calculated for each group using the Newey-West estimator which provides a covariance matrix estimator that is consistent in the presence of both heteroskedasticity and autocorrelation.

While there are clearly more sophisticated methods available for estimating convergence (see for example, Quah, 1993; Bernard and Durlauf, 1995), the primary attractiveness of this

\footnotetext{
${ }^{29}$ This is an unweighted average of the group's log per capita incomes at time $t$. We can also give weights to countries in the groups according to their GNPs, and use a weighted average.

${ }^{30}$ The half life $(h)$ is derived in Ben-David (1993) as follows. If $y_{t+1}=\Phi y_{t}$, then $y_{t+h}=\Phi^{h} y_{t}$. Since $y_{t+x}=$ $0.5 y_{t}$ by definition, then $0.5 y_{t}=\Phi^{h} y_{t}$, or $0.5=\Phi^{h}$. Taking logs of both sides and dividing by $\log \Phi$ gives $h$ as $\log 0.5 / \log \Phi$.
} 
measure lies in its simplicity, its applicability to relatively small groups of countries, and its usefulness for conducting relatively quick and simple convergence comparisons across groups that include different country compositions.

Results of the Eq. (2) estimation for each of the trade groups are reported in Table 2 in the Appendix. The source country of each group is listed first, followed by the number of countries in each trade group, the group's estimated convergence coefficient, standard error, and the half-life (double-life) of the convergence (divergence) process. The results indicate that most of the trade groups exhibite income convergence; 18 of the 21 groups have a $\hat{\phi}$ less than 1 , with 11 of these outcomes significant at the $10 \%$ level at least. Only 3 of the 21 trade groups have an estimated convergence coefficient greater than unity and only one of these three outcomes is significant at the $5 \%$ level.

When the trade groups are formed according to the total trade between the countries rather than intra-industry trade, we see a significant decrease in the number of the groups which exhibit income convergence. The results in Table 3 in the Appendix show that 14 of the 23 groups have a $\hat{\phi}$ less than 1 , with only 6 of these outcomes significant at the $10 \%$ level at least.

\subsection{Random Country Groupings}

Are the results in the last section indicative of intra-industry trade-related convergence, or does any random grouping of these same countries might produce similar results? To test this, the 21 source countries are regrouped into their many different possible subgroups, their convergence coefficients are estimated, and the results are compared with those in Table 2. Since the intraindustry trade-based groups ranged in sizes of 3, 4, 5, 7, and 8; the various random subgroups will also range in the same sizes. For each subgroup, 500 random samples are estimated. As it is 
evident from Table 4 in the Appendix, a random grouping of any size is more likely to produce $\hat{\phi}$ $>1$, i.e. a divergence outcome. Percentage of $\hat{\phi}$ that is greater than 1 is $52 \%, 60 \%, 70 \%, 80 \%$, and $82 \%$ for the group sizes of $3,4,5,7$, and 8 , respectively.

Table 5 in the Appendix makes it easier to compare the results. For example, Austria's intra-industry trade-based group consists of 8 countries and it has an estimated $\hat{\phi}$ of 0.9953 . It can be seen that the likelihood of drawing a randomly constructed group of 8 countries out of the original 24 countries and getting a $\hat{\phi}$ less than 0.9953 is only $15 \%$.

\subsection{Exclusion of Partners}

Is it possible that all of this convergence within groups might be towards one country that is common to most of the groups? The United States and Ireland are two candidates for this type of bias, since they are trade partners in 8 of the 18 groups which had a $\hat{\phi}$ less than 1 . Their removal from each of the groups would then reduce the convergence bias, if it exists.

The estimated convergence coefficients for the intra-industry trade-based groups are below unity in all of the 8 groups when USA is excluded ( 6 of them are significant) and they are below unity in 7 of the 8 groups when Ireland is excluded from the groups (6 of them are significant). As it can be seen in Table 6 and in Table 7 in the Appendix, the exclusion of the USA and Ireland does not significantly change the high incidence of convergence within the trade groups. The last column in the tables makes it easier to compare the results. For example, in Table 6, Belgium's intra-industry trade-based group consists of 7 countries when USA is excluded and it has an estimated $\hat{\phi}$ of 0.9773 . It can be seen that the likelihood of drawing a 
randomly constructed group of 7 countries out of the original 24 countries (with no USA included) and getting a $\hat{\phi}$ less than 0.9773 is only $13 \%$.

\subsection{Language and Proximity}

Many of the countries that comprise the trade groups share other characteristics as well. For example, 6 of the source countries share English as their primary language. Moreover, quite a few of the countries are also in close geographical proximity to one another. Since common language and proximity facilitate information flows and these flows are a source of income convergence, then it is possible that the income convergence exhibited by the trade groups is due less to trade flows than to proximity or common language. After regrouping the countries to reflect common languages or geographical closeness, the degree of convergence within each of these groups could be compared with the results of the intra-industry trade-based groups.

Geographical proximity is defined to be a neighboring country with a common border, or when the border is water, the nearest neighbor across the water. In keeping with the trade group's minimum size of three, only proximity and language-based groups with at least three countries were examined. Under these criteria, there are 16 regional groups and one language group (English) the composition of which may be found in Table 8 in the Appendix. As the results in Table 9 in the Appendix indicate, there is no evidence of significant convergence within the group of English-speaking countries. As far as geography-based groups are concerned, just 7 of 16 groups (less than one half of the groups) exhibit income convergence at a significance level of $10 \%$ or higher. On the other hand we had found in Section 4.1 that approximately two-thirds (13 of 21) of the intra-industry trade-based groups exhibited significant convergence. Thus, the tendency towards convergence appears to be stronger when the basis for constructing groups is trade rather than proximity or common language. 


\section{Conclusions}

In this paper we attempt to present evidence that income convergence among countries seems to be a common feature among countries that trade extensively with one another, especially in those industries which share the typical characteristics of industries involved in intra-industry trade, such as product differentiation, economies of scale, and rapid innovation.

Grouping countries according to their primary intra-industry trade partnerships tends to produce significant income convergence within the groups. When the trade groups are formed according to the total trade between the countries rather than intra-industry trade, we see a significant decrease in the number of the groups which exhibit income convergence. Significant income convergence is not a common outcome among countries when they are grouped randomly. Moreover, this convergence is not towards one country that is common to most of the groups, but is instead an outcome that tends to be relatively robust to the exclusion of trade patterns that are members in most of the groups. Finally, the tendency towards convergence appears to be considerably stronger when the basis for constructing groups is trade rather than proximity or common language. 


\section{References}

Balance, R.H., Forstner, H., and Sawyer W.C. (1992) 'An empirical examination of the role of vertical product differentiation in north-south trade', Weltwirtschafliches rchiv, 128: 330-8.

Balassa, B. (1986) 'The determinants of intra-industry specialization in United States trade', Oxford Economic Papers, 38: 220-233.

Barro, R.J. (1991) 'Economic growth in a cross-section of countries', Quarterly Journal of Economics, 106: 407-443.

Barro, R.J. and Sala-i Martin, X. (1995) Economic Growth. New York: McGraw Hill.

Baumol, W.J. (1986) 'Productivity growth, convergence, and welfare: What the long-run data show', American Economic Review, 76: 1072-1085.

Baumol, W.J., Blackman, S.A.B., and Wolff, E.N. (1989) Productivity and American Leadership: The Long View. Cambridge: MIT Press.

Ben-David, D. (1993) 'Equalizing exchange: Trade liberalization and income convergence' Quarterly Journal of Economics, 108: 653-679.

Ben-David, D. (1994a) 'Income disparity among countries and the effects of freer trade', in L.L. Pasinetti and R.M. Solow (eds), Economic Growth and the Structure of Long Run Development. London: Macmillan.

Ben-David, D. (1994b) 'Convergence clubs and diverging economies', discussion paper no. 922, CEPR.

Ben-David, D. (1996) 'Trade and convergence among countries', Journal of International Economics, 40: 279-298. 
Ben-David, D. and Loewy, M.B. (1996) 'Knowledge dissemination, capital accumulation, trade, and endogeneous growth', discussion paper no. 1335, CEPR.

Ben-David, D. and Loewy, M.B. (2000) 'Knowledge dissemination, capital accumulation, trade, and endogeneous growth', Oxford Economic Papers, 52: 637-650

Bergstrand, J.H. (1983) 'Measurement and determinants of intra-industry international trade', in P.K.M. Tharakan, ed., Intra-Industry Trade: Empirical and Methodological Aspects. Amsterdam: North Holland.

Bergstrand, J.H. (1990) 'The Heckscher-Ohlin-Samuelson model, the Linder hypothesis and the determinants of bilateral intra-industry trade', The Economic Journal, 100: 1216-1229.

Bernard, A.B. and Durlauf, S.N. (1995) 'Convergence in international output', Journal of Applied Econometrics, 10: 97-108.

Bernard, A.B. and Jones, C.I. (1996) 'Productivity and convergence across U.S. states and industries', Long-run Economic Growth, 21: 113-135.

Bhagwati, J.N. and Davis, D. (1994) 'Intra-industry trade: Issues and theory', discussion paper no. 1695, Harvard University.

Cass, D. (1965) 'Optimum growth in an aggregative model of capital accumulation', Review of Economic Studies, 32: 233-240.

Caves, R.E. (1981) 'Intra-industry trade and market structure in the industrial countries', Oxford Economic Papers, 33: 203-223.

De la Fuente, A. (1997) 'The empirics of growth and convergence: A selective review', Journal of Economic Dynamics and Control, 21: 23-73. 
Dollar, D. (1992) 'Outward-oriented developing economies really do grow more rapidly: Evidence from 95 LCDs, 1976-1985', Economic Development and Cultural Change, 40: 523-544.

Durlauf, S. and Johnson, P.A. (1995) 'Multiple regimes and cross-country growth behavior', Journal of Applied Econometrics, 10: 365-384.

Edwards, S. (1993) 'Openness, trade liberalization, and growth in developing countries', Journal of Economic Literature, 31:1358-1393.

Ethier, W.J. (1982) 'National and international returns to scale in the modern theory of international trade', The American Economic Review, 72: 389-405.

Fukasaku, K. (1992) 'Economic regionalization and intra-industry trade: Pacific-Asian perspective', technical papers no. 53, OECD Development Centre.

Globerman, S. and Dean, J.W. (1990) 'Recent trends in intra-industry trade and their implications for future trade liberalization', Weltwirtschafliches Archiv, 126: 25-49.

Greenaway, D. (1983) International Trade Policy: From Tariffs to the New Protectionism. London: Macmillan.

Greenaway, D. and Milner, C.R. (1986) The Economics of Intra-Industry Trade. Oxford: Blackwell.

Grubel, H.G. and Lloyd, P.J. (1975) Intra-Industry Trade. London: Macmillan.

Gunasekera, H.D. (1989) 'Intra-industry specialization in production and trade in newly industrialized countries: A conceptual framework and some empirical evidence from East Asia', World Development, 17: 1279-1287.

Hamilton, C. and Kniest, P. (1991) 'Trade liberalization, structural adjustment, and intra-industry trade: A note', Weltwirtschaftliches Archiv, 127: 356-367. 
Harrison, A. (1995) Openness and growth: A time-series cross country analysis for developing countries', working paper no. 5221, NBER.

Havrylyshyn, O. and Civan, E. (1983) 'Intra-industry trade and the stage of development: A regression analysis of industrial and developing countries', in P.K.M. Tharakan, ed., Intra Industry Trade: Empirical and Methodological Aspects. Amsterdam: North Holland.

Heckscher, E. (1919) 'The effect of foreign trade on the distribution of income', Ekonomisk Tidskrift, 21: 1-32.

Helpman, E. (1981) 'International trade in the presence of product differentiation, economies of scale, and monopolistic competition: A Chamberlinian-Heckscher-Ohlin approach', Journal of International Economics, 11: 305-340.

Helpman, E. and Krugman, P.R. (1989) Trade Policy and Market Structure. Cambridge: MIT Press.

Henrekson, M., Torstensson, J., and Torstensson, R. (1996) 'Growth effects of European integration', discussion paper no. 1465, CEPR.

Kol, J. and Mennes, L.B.M. (1989) 'Corrections for trade imbalance: A survey', Weltwirtschaftliches Archiv, 125: 703-717.

Kristensen, T. (1982) Development in Rich and Poor Countries. New York: Praeger.

Krugman, P.R. (1979) 'A model of innovation, technology transfer, and the world distribution of income', Journal of Political Economy, 87: 253-266.

Krugman, P.R. (1981) 'Intra-industry specialization and the gains from trade', Journal of Political Economy, 89: 959-973.

Laird, S. (1981) 'Intra-industry trade and the expansion, diversification and integration of the trade of the developing countries', Trade and Development: A UNCTAD Review, 3: 79-101. 
Lancaster, K. (1979) Variety, Equity, and Efficiency. New York: Columbia University Press.

Lee, Y.S. (1987) 'Intra-industry trade in the Pacific Basin', International Economic Journal, 1: 75-89.

Levine, R. and Renelt, D. (1992) 'A sensitivity analysis of cross-country growth regressions', American Economic Review, 82: 942-963.

Linder, S.B. (1961) An Essay on Trade and Transformation. New York: Wiley.

Loertscher, R. and Wolter, F. (1980) 'Determinants of intra-industry trade: Among countries and across industries', Weltwirtschaftliches Archiv, 116: 280-293.

Lucas, R.E. (1988) 'On the mechanics of economic development', Journal of Monetary Economics, 22: 3-42.

Lundberg, L. (1982) 'Intra-industry trade: The case of Sweden', Weltwirtschafliches Archiv, 118: 302-316.

Lundberg, L. (1992) 'The structure of Swedish international trade and specialization: Old and new explanations', Weltwirtschafliches Archiv, 128: 266-287.

Meyer, B.D. (1994) 'Natural and quasi-experiments in economics', working paper, Vol. 170, NBER.

Mankiw, N.G., Romer, D., and Weil, D.N. (1992) 'A contribution to the empirics of economic growth', Quarterly Journal of Economics, 107: 407-437.

Ohlin, B. (1933) Interregional and International Trade. Cambridge: Harvard University Press.

O'Rourke, K.H. (1996) 'Trade, migration, and convergence: An historical perspective', discussion paper no. 1319, CEPR. 
Quah, D. (1993) 'Galton's fallacy and tests of the convergence hypothesis', ScandinavianJournal of Economics, 95: 427-443.

Quah, D. (1996) 'Convergence empirics across countries with capital mobility', Journal of Economic Growth, 1: 95-124.

Ray, E.J. (1991) 'U.S. protection and intra-industry trade: The message to developing countries', Economic Development and Cultural Change, 40: 169-187.

Romer, P.M. (1986) 'Increasing returns and long run growth', Journal of Political Economy, 94: 1002-1038.

Sachs, J.D. and Warner, A. (1995) 'Economic convergence and economic policies', working paper no. 5039, NBER.

Sala-i Martin, X. (1996) 'The classical approach to convergence analysis', The Economic Journal, 106: 1019-1036.

Samuelson, P.A. (1948) 'International trade and the equalization of factor prices', Economic Journal, 58: 163-184.

Slaughter, M.J. (1997) 'Per capita income convergence and the role of international trade', American Economic Review, 87: 194-199.

Slaughter, M.J. (2001) 'Trade liberalization and per capita income convergence: A difference in differences analysis', Journal of International Economics, 55: 203-228.

Solow, R.M. (1956) 'A contribution to the theory of economic growth', Quarterly Journal of Economics, 70: 65-94.

Temple, J. (1999) 'The new growth evidence', Journal of Economic Literature, 37: 112- 156. 
Tharakan, P.K.M. (1986) 'The intra-industry trade of Benelux with the developing world', Weltwirtscaftliches Archiv, 12: 131-149.

Toh, K. (1982) ‘A cross section analysis of intra-industry trade in U.S. manufacturing industries', Weltwirtschafliches Archiv, 118: 281-301.

Vona, S. (1991) 'On the measurement of intra-industry trade: Some further thoughts', Weltwirtschafliches Archiv, 127: 678-700. 


\title{
Appendix
}

Table 1. List of Countries in Trade Groups (IIT-Based Groups)

\author{
Source Country Countries in Group \\ Austria Belgium, France, Germany, Israel, Italy, Sweden, USA \\ Belgium France, Germany, Ireland, Israel, Netherlands, USA \\ Canada Denmark, Ireland, Israel, Netherlands, Norway, USA \\ Denmark Austria, Canada, Finland, Germany, Sweden, Switzerland, USA \\ Finland Austria, Belgium, Ireland, Italy, Luxemburg, Sweden \\ France Austria, Belgium, Finland, Ireland, Italy, Switzerland, USA \\ Germany Austria, Ireland, Portugal \\ Iceland Greece, Portugal \\ Ireland Japan, UK, USA \\ Israel Greece, Iceland, USA \\ Italy Austria, Finland, France, Ireland, Sweden, UK, USA \\ Japan Ireland, Sweden \\ Luxemburg Sweden, UK \\ Netherlands Belgium, Canada, Germany, Sweden \\ Norway Australia, Canada, UK \\ Portugal Australia, Austria, Germany, Iceland \\ Spain Denmark, France, Ireland, Italy, Switzerland, UK \\ Sweden Austria, Denmark, France, Italy, Japan, Netherlands, UK \\ Switzerland Austria, Denmark, France, Italy, Luxemburg, Sweden \\ UK France, Italy, Netherlands, Portugal, Spain, Sweden, USA \\ USA Austria, Canada, France, Ireland, Israel, UK
}


Table 2. Trade Groups' Convergence Coefficients (IIT-Based Groups)

\begin{tabular}{lccccc} 
Source Country & $\#^{\mathrm{b}}$ & $\hat{\phi}$ & Standard Error & Half-life & Double-life \\
Austria & 8 & 0.9953 & 0.0055 & 147 & 0 \\
Belgium & 7 & 0.9867 & $0.0065^{* *}$ & 52 & 0 \\
Canada & 7 & 0.9913 & $0.0052^{*}$ & 79 & 0 \\
Denmark & 8 & 0.9781 & $0.0057 * * *$ & 31 & 0 \\
Finland & 7 & 0.9951 & 0.0094 & 141 & 0 \\
France & 8 & 0.9788 & $0.0051^{* * *}$ & 32 & 0 \\
Germany & 4 & 0.9961 & 0.0052 & 177 & 0 \\
Iceland & 3 & 0.9985 & 0.0053 & 462 & 0 \\
Ireland & 4 & 0.9821 & $0.0076 * *$ & 38 & 0 \\
Israel & 4 & 1.0027 & 0.0047 & 0 & 257 \\
Italy & 8 & 0.9812 & $0.0068 * *$ & 37 & 0 \\
Japan & 3 & 0.9802 & $0.0080^{* *}$ & 35 & 0 \\
Luxemburg & 3 & 1.0283 & 0.0125 & 0 & 25 \\
Netherlands & 5 & 0.9737 & $0.0133 * *$ & 26 & 0 \\
Norway & 4 & 1.0167 & 0.0070 & 0 & 42 \\
Portugal & 5 & 0.9941 & 0.0053 & 117 & 0 \\
Spain & 7 & 0.9827 & $0.0043 * * *$ & 40 & 0 \\
Sweden & 8 & 0.9952 & 0.0065 & 144 & 0 \\
Switzerland & 7 & 0.9921 & 0.0071 & 87 & 0 \\
UK & 8 & 0.9927 & $0.0033 * *$ & 95 & 0 \\
USA & 7 & 0.9859 & $0.0069 * *$ & 49 & 0 \\
\hline
\end{tabular}

${ }^{\text {a }}$ Source countries include those countries for which there are at least two other countries such that the intra-industry trade share of the total trade between the source country and the other country is more than $85 \%$ in 2002. Australia, Greece, and New Zealand do not satisfy this criterion.

${ }^{\mathrm{b}}$ \# represents the number of countries in each group. The countries in each group are in Table 1.

${ }^{* * *}$ Significantly less than 1 at the $1 \%$ level.

${ }^{* *}$ Significantly less than 1 at the $5 \%$ level.

${ }^{*}$ Significantly less than 1 at the $10 \%$ level. 
Table 3. Trade Groups' Convergence Coefficients (Trade-Based Groups)

\begin{tabular}{|c|c|c|c|c|c|}
\hline$\underline{\text { Source Country }}^{\mathrm{a}}$ & $\#^{\mathrm{b}}$ & $\hat{\phi}$ & Standard Error & Half-life & Double-life \\
\hline Australia & 6 & 1.0067 & 0.0067 & 0 & 104 \\
\hline Austria & 5 & 0.9962 & 0.0051 & 182 & 0 \\
\hline Belgium & 7 & 0.9959 & 0.0047 & 169 & 0 \\
\hline Denmark & 8 & 1.0048 & 0.0059 & 0 & 145 \\
\hline Finland & 8 & 0.9914 & 0.0053 & 80 & 0 \\
\hline France & 8 & 0.9947 & 0.0043 & 130 & 0 \\
\hline Germany & 10 & 0.9882 & $0.0042 * * *$ & 58 & 0 \\
\hline Greece & 7 & 1.0013 & 0.0046 & 58 & 0 \\
\hline Iceland & 9 & 0.9981 & 0.0047 & 364 & 0 \\
\hline Ireland & 7 & 0.9812 & $0.0071 * * *$ & 36 & 0 \\
\hline Israel & 7 & 0.9877 & $0.0053 * *$ & 56 & 0 \\
\hline Italy & 8 & 0.9886 & $0.0041 * * *$ & 56 & 0 \\
\hline Japan & 3 & 1.0031 & 0.0057 & 0 & 223 \\
\hline Luxemburg & 6 & 1.0228 & 0.0091 & 0 & 30 \\
\hline Netherlands & 7 & 0.9959 & 0.0047 & 168 & 0 \\
\hline New Zealand & 6 & 1.0067 & 0.0067 & 0 & 103 \\
\hline Norway & 8 & 1.0048 & 0.0059 & 0 & 144 \\
\hline Portugal & 5 & 0.9922 & 0.0048 & 88 & 0 \\
\hline Spain & 7 & 0.9948 & 0.0043 & 132 & 0 \\
\hline Sweden & 10 & 1.0002 & 0.0061 & 0 & 3466 \\
\hline Switzerland & 7 & 0.9855 & $0.0046^{* * *}$ & 47 & 0 \\
\hline UK & 9 & 0.9899 & $0.0044 * *$ & 68 & 0 \\
\hline$\underline{\mathrm{USA}}$ & 5 & 1.0023 & 0.0072 & 0 & 301 \\
\hline
\end{tabular}

${ }^{\text {a }}$ Source countries include those countries for which there are at least two other countries such that the trade share between the source country and the other country is more than $4 \%$ in 2002. Australia, Greece, and New Zealand do not satisfy this criterion.

${ }^{* * *}$ Significantly less than 1 at the $1 \%$ level.

${ }^{* *}$ Significantly less than 1 at the $5 \%$ level.

${ }^{*}$ Significantly less than 1 at the $10 \%$ level. 
Table 4. Distribution of Convergence Coefficients

\begin{tabular}{lrrrrr}
\hline \multicolumn{6}{c}{ Group size } \\
\hline$\hat{\phi}$ & 3 & 4 & 5 & 7 & 8 \\
\hline 1 & 48 & 40 & 30 & 20 & 18 \\
0.99 & 33 & 25 & 18 & 12 & 10 \\
0.98 & 23 & 18 & 12 & 7 & 5 \\
0.97 & 15 & 12 & 7 & 3 & 2 \\
0.96 & 12 & 8 & 5 & 1.6 & 1.2 \\
0.95 & 10 & 5 & 2 & 1.2 & 1.0 \\
0.94 & 8 & 3 & 1 & 0.6 & 0.4 \\
0.93 & 5 & 2 & 0.8 & 0.4 & 0.2 \\
0.92 & 4 & 1 & 0.4 & 0.2 & 0.2
\end{tabular}


Table 5. Comparison of the Results when Groups are Formed Randomly

\begin{tabular}{llcc} 
Source Country $^{\mathrm{a}}$ & $\#^{\mathrm{b}}$ & $\hat{\phi}^{\mathrm{c}}$ & Probability $^{\mathrm{d}}$ \\
Austria & 8 & 0.9953 & 15 \\
Belgium & 7 & 0.9867 & 10 \\
Canada & 7 & 0.9913 & 13 \\
Denmark & 8 & 0.9781 & 4 \\
Finland & 7 & 0.9951 & 16 \\
France & 8 & 0.9788 & 4 \\
Germany & 4 & 0.9961 & 34 \\
Iceland & 3 & 0.9985 & 45 \\
Ireland & 4 & 0.9821 & 20 \\
Italy & 8 & 0.9812 & 6 \\
Japan & 3 & 0.9802 & 23 \\
Netherlands & 5 & 0.9737 & 9 \\
Portugal & 5 & 0.9941 & 22 \\
Spain & 7 & 0.9827 & 8 \\
Sweden & 8 & 0.9952 & 14 \\
Switzerland & 7 & 0.9921 & 13 \\
UK & 8 & 0.9927 & 12 \\
USA & 7 & 0.9859 & 10 \\
\hline
\end{tabular}

${ }^{\text {a }}$ Source countries include those countries for which the intra-industry trade-based group exhibited income convergence.

${ }^{\mathrm{b}}$ \# represents the number of countries in each group. The countries in each group are listed in Table 1.

c $\Phi$ represents the intra-industry trade-based group's estimated convergence coefficient.

${ }^{d}$ Probability denotes the likelihood of drawing a randomly constructed group of corresponding size and getting a convergence coefficient which is less than $\Phi$ that is listed in the third column of the table. 
Table 6. Comparison of the Results when USA is Excluded

$\begin{array}{lcccc}\text { Source Country }^{\mathrm{a}} & \#^{\mathrm{b}} & \hat{\phi}^{\mathrm{c}} & \text { Standard Error } & \text { Probability }^{\mathrm{d}} \\ \text { Belgium } & 7 & 0.9773 & 0.0056^{* * *} & 13 \\ \text { Canada } & 7 & 0.9918 & 0.0062 & 15 \\ \text { Denmark } & 8 & 0.9727 & 0.0125^{* *} & 6 \\ \text { France } & 8 & 0.9752 & 0.0064^{* * *} & 8 \\ \text { Ireland } & 4 & 0.9835 & 0.0045^{* * *} & 18 \\ \text { Italy } & 8 & 0.9861 & 0.0137 & 5 \\ \text { UK } & 8 & 0.9909 & 0.0049^{*} & 11 \\ \text { USA } & 7 & 0.9859 & 0.0057^{* *} & 15 .\end{array}$

${ }^{a}$ Source countries include those countries for which the intra-industry trade-based group exhibited income convergence and USA was in the group.

${ }^{\mathrm{b}}$ \# represents the number of countries in each group. The countries in each group are listed in Table 1.

' $\Phi$ represents the intra-industry trade-based group's estimated convergence coefficient when USA is removed from the group.

${ }^{d}$ Probability denotes the likelihood of drawing a randomly constructed group of corresponding size and getting a convergence coefficient which is less than $\Phi$ that is listed in the third column of the table.

${ }^{* * *}$ Significantly less than 1 at the $1 \%$ level.

${ }^{* *}$ Significantly less than 1 at the $5 \%$ level.

${ }^{*}$ Significantly less than 1 at the $10 \%$ level. 
Table 7. Comparison of the Results when Ireland is Excluded

\begin{tabular}{lcccc} 
Source Country $^{\mathrm{a}}$ & $\#^{\mathrm{b}}$ & $\hat{\phi}^{\mathrm{c}}$ & Standard Error & Probability $^{\mathrm{d}}$ \\
Belgium & 7 & 0.9923 & $0.0035^{* *}$ & 11 \\
Canada & 7 & 0.9876 & $0.0041^{* * *}$ & 17 \\
France & 8 & 0.9827 & $0.0026^{* * *}$ & 8 \\
Ireland & 4 & 0.9835 & $0.0038^{* * *}$ & 15 \\
Italy & 8 & 0.9903 & $0.0054^{*}$ & 9 \\
Japan & 3 & 1.0092 & 0.0059 & 28 \\
Spain & 7 & 0.9859 & $0.0061^{* *}$ & 18 \\
USA & 7 & 0.9992 & 0.0036 & 13 \\
\hline
\end{tabular}

${ }^{a}$ Source countries include those countries for which the intra-industry trade-based group exhibited income convergence and Ireland was in the group.

${ }^{\mathrm{b}}$ \# represents the number of countries in each group. The countries in each group are listed in Table 1.

c $\Phi$ represents the intra-industry trade-based group's estimated convergence coefficient when Ireland is removed from the group.

${ }^{\mathrm{d}}$ Probability denotes the likelihood of drawing a randomly constructed group of corresponding size and getting a convergence coefficient which is less than $\Phi$ that is listed in the third column of the table. *** Significantly less than 1 at the $1 \%$ level.

** Significantly less than 1 at the 5\%level.

${ }^{*}$ Significantly less than 1 at the $10 \%$ level. 
Table 8. List of Countries in Language and Geographical Groups

Source Country Countries in Group

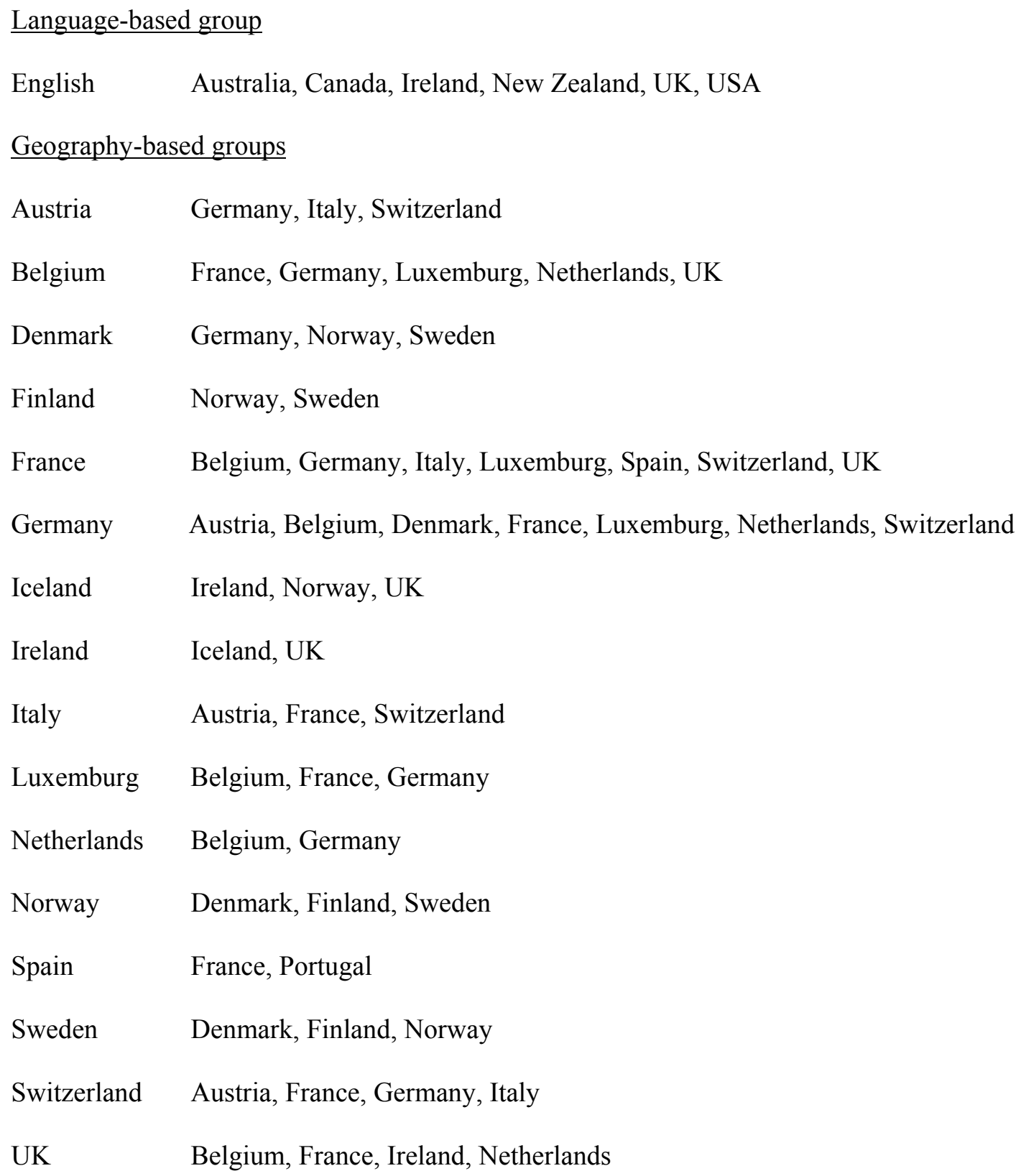


Table 9. Convergence Coefficients of Groups Based on Language and Proximity

Source Country $^{\mathrm{a}} \quad \#^{\mathrm{b}} \quad \hat{\phi} \quad$ t-statistic.

$\underline{\text { Language-based group }}$

$\begin{array}{llll}\text { English } & 6 & 0.9879 & 0.0076\end{array}$

Geography-based groups

\begin{tabular}{llll} 
Austria & 4 & 0.9787 & $0.0044^{* * *}$ \\
Belgium & 6 & 1.0307 & 0.0097 \\
Denmark & 4 & 1.0091 & 0.0103 \\
Finland & 3 & 1.0067 & 0.0123 \\
France & 8 & 0.9953 & 0.0056 \\
Germany & 8 & 0.9934 & 0.0082 \\
Iceland & 4 & 0.9864 & 0.0089 \\
Ireland & 3 & 0.9771 & $0.0111^{* *}$ \\
Italy & 4 & 0.9824 & $0.0041^{* * *}$ \\
Luxemburg & 4 & 1.0321 & 0.0092 \\
Netherlands & 3 & 0.9001 & $0.0319^{* * *}$ \\
Norway & 4 & 0.9985 & 0.0121 \\
Spain & 3 & 0.9911 & $0.0046^{*}$ \\
Sweden & 4 & 0.9985 & 0.0121 \\
Switzerland & 5 & 0.9789 & $0.0046^{* * *}$ \\
UK & 5 & 0.9673 & $0.0106^{* * *}$. \\
\hline
\end{tabular}

${ }^{\text {a }}$ Source countries include those countries for which proximity and language-based groups contain at least three countries.

${ }^{\mathrm{b}}$ \# represents the number of countries in each group. The countries in each group are listed in Table 8.

*** Significantly less than 1 at the $1 \%$ level.

${ }^{* *}$ Significantly less than 1 at the $5 \%$ level.

${ }^{*}$ Significantly less than 1 at the $10 \%$ level. 


\section{Chapter 4. Determinants of Intra-Industry Trade in a Multi- Country \& Multi-Industry Framework: An Empirical Analysis}

\section{Introduction}

Traditional theories of international trade have not been extended to incorporate product differentiation, economies of scale, and monopolistic competition; only in the last two decades we have seen the emergence of a sizeable literature that links trade theory and industrial organization, beginning with the studies of Krugman (1979) and Lancaster (1979).

One group of models that has emerged through the synthesis of international economics and industrial organization includes the models of intra-industry trade. Intra-industry trade models provide an explanation for the simultaneous export and import of fairly similar goods. In these models countries' markets are characterized by imperfect competition involving differentiated products and increasing returns to scale. The opening of trade results in a greater product variety and an increased competition with a consequent reduction in costs and prices.

Trade theorists have provided rigorous and elegant models generating intra-industry trade. In their pioneering study which fundamentally changed the way economists view the causes of international trade, Grubel and Lloyd (1975) established the extent of intra-industry trade in different industrial nations, considered some measurement issues, and investigated possible causes and consequences of such trade. To point out this fundamental change, Helpman and Krugman (1989: p.133) refer to intra-industry trade as "one of the key empirical reasons for emphasizing the role of increasing returns and imperfect competition in the world economy". 
Krugman (1979), Lancaster (1980), and Helpman (1981) developed intra-industry trade theory (IIT) using a monopolistic competition model to explain modern trade patterns. The model allows for the presence of increasing returns to scale in production and for differentiated products. Intra-industry trade may arise under their framework. Krugman (1979) first generated a model in which monopolistically competitive firms produced differentiated products with an increasing returns to scale (IRTS) technology. He later extended this model (Krugman, 1981) to allow for both intra- and inter-industry trade. These models were further developed in Helpman and Krugman (1985). In general, these models are characterized by increasing returns on the production side and a utility model that rewards product diversity on the consumption side. A common result in these models is that countries trade similar goods.

Since the introduction of the concept of intra-industry trade, a large literature developed on the subject. Early efforts at the measurement of the extent of intra-industry trade were followed by contributions to the theory of intra-industry trade. Furthermore, many studies have attempted to identify the determinants of intra-industry trade. They have considerable differences in model specification, estimation techniques, and the level of industry aggregation ${ }^{31}$.

In the literature, one group of authors has concentrated on the measurement of intraindustry trade. Another group has taken econometric approaches and attempted to test the theory of intra-industry trade with data on an observed country or a group of countries. This research belongs to the second group. This study provides recent evidence on determinants of the intraindustry trade in a multi-country \& multi-industry framework. Bilateral trade data of the year 2002 at three-digit SITC (Standard International Trade Classification) industry groups is used for 24 developed countries, namely Australia, Austria, Belgium, Canada, Denmark, Finland, France,

\footnotetext{
${ }^{31}$ For a comprehensive survey of the empirical literature, see Greenaway and Milner (1986).
} 
Germany, Greece, Iceland, Ireland, Israel, Italy, Japan, Luxembourg, the Netherlands, New Zealand, Norway, Portugal, Spain, Sweden, Switzerland, United Kingdom, and USA.

First, a theoretical summary of a two-country model based on product differentiation and economies of scale is provided, following Helpman (1981) and Helpman and Krugman (1985). Then, using this model, the determinants of bilateral intra-industry trade are analyzed in the trade of each country with every other country in each industry category. The hypotheses that are tested in this study investigate the effect of the following country characteristics on the bilateral intraindustry trade: average country size, average per capita income, country size difference, per capita income difference, distance, common border, participation in economic integration systems, and common language.

This paper follows closely the studies of Helpman (1981), Helpman and Krugman (1985, ch.7), and Kim and Oh (2001). This research contributes to the existing literature of intra-industry trade in several ways. This study employs very recent trade data, namely data of 2002. Second, the data in the analysis is wide-ranging ${ }^{32} ; 24$ developed countries are included. Third, this study concentrates on testing country characteristics while most empirical studies ${ }^{33}$ of intra-industry trade have concentrated on testing industry characteristics such as economies of scale and product differentiation. Fourth, the empirical analysis covers a wide variety of country characteristics together, which are developed separately in the literature, i.e., average country size, average per

\footnotetext{
${ }^{32}$ The total number of observations is expected to be $12,144\left(={ }_{24} \mathrm{C}_{2}(=276)\right.$ country combinations $\mathrm{x} 44$ SITC categories) but in considerable amount of cases $(18 \%)$ neither exports nor imports exist in bilateral trade flows. Then the index of intra-industry trade is not defined and these observations are excluded from the analysis.

${ }^{33}$ Clark (1993), Lundberg (1992), Ray (1991), Hamilton and Kniest (1991), Marvel and Ray (1987), Balassa (1986), Greenaway and Milner (1984).
} 
capita income, country size difference, per capita income difference, distance, common border, participation in economic integration systems, and common language.

The empirical results show that the extent of intra-industry trade is positively correlated with average GNP, average GNP/capita, and the existence of a common border; and it is negatively correlated with differences in GNP and GNP/capita, and distance. All the variables are highly significant statistically. The EU and NAFTA dummy variables have the expected positive sign and are highly significant statistically. The regression coefficients of the language dummy variables have a positive sign, but their level of statistical significance varies. Moreover, the results show that the variables Average GNP and Difference in GNP are the country characteristics that contribute the most to the explanatory power of the regression equations. 


\section{Literature Review}

The traditional Heckscher-Ohlin-Samuelson model leads us to expect that trade should typically be between countries with different factor endowments - capital-abundant countries should trade with labor-abundant; the composition of trade should reflect the sources of comparative advantage; and trade should have strong effects on income distribution, i.e. when a country trades capital-intensive exports for labor-intensive imports, its workers should end up worse off.

What empirical studies found out was that trends in world trade did not seem to accord with these expectations. The largest and rapidly growing part of world trade was trade among the industrial countries, which seemed fairly similar in their factor endowments and were clearly becoming more similar over time.

In the early 1980 s came the crucial theoretical development and the theory of intraindustry trade has become part of mainstream international economics, when subsequent investigations were motivated by theories based on horizontal product differentiation, monopolistic competition, and increasing returns to scale. This synthesis of industrial organization and international trade was first proposed independently in papers by Krugman (1979), Dixit and Norman (1980), and Lancaster (1980). It was further extended by Krugman (1981), Helpman (1981), Ethier (1982), and others ${ }^{34}$.

The pioneering Helpman-Krugman model demonstrates intra-industry trade, based on specialization in different varieties due to economies of scale in the manufacturing sector (Helpman, 1981; Helpman and Krugman, 1985). The model includes both the elements of

\footnotetext{
${ }^{34}$ For a survey of the theoretical literature of intra-industry trade, see Bhagwati and Davis (1994).
} 
product differentiation and monopolistic competition. Every firm chooses a variety and its price to maximize profits, taking as given the variety choice and pricing strategy of the other producers in the industry. In this case every firm ends up producing a different variety of the product. Under a demand structure within which there is a taste of variety, for every pair of countries that produce varieties of the good, intra-industry trade will be observed. Under monopolistic competition, each country will produce different varieties of the product, every variety will be demanded in both countries and consumers will benefit from an increased number of varieties and from lower prices.

In analyzing the factors that determine the extent of intra-industry trade in an intercountry context, Linder (1961) advanced the hypothesis that the extent of trade in differentiated products will be the greater, the more similar are income levels among the trading countries. This hypothesis reflects the assumption that similarities in income levels are associated with similarities in demand structures. Helpman (1981) provided proof of the proposition that the extent of intra-industry trade will be the greater, the more similar is the size of the trading partners. This proposition can be expressed in the form of a testable hypothesis that the extent of intra-industry trade is negatively correlated with inter-country differences in regard to the gross national product, taken to be a measure of market size.

Empirical studies on the intra-industry trade of the developing countries remained an underresearched area for a long time, but increasing attention has been paid to this area in recent years $^{35}$. Most previous econometric studies have attempted to explain the intra-industry trade of

\footnotetext{
${ }^{35}$ Three such studies (Laird, 1981; Lee, 1987; and Gunasekera, 1989) are general reviews. Some other papers include Havrylyshyn and Civan, 1983; Tharakan, 1986; Ray, 1991; and Fukasaku, 1992.
} 
developed countries ${ }^{36}$. This may be partly because of the belief that the phenomenon of intraindustry trade is significant only among industrialized countries.

Two studies focus on the most direct proposition of the Helpman-Krugman model, that the proportion of intra-industry as opposed to inter-industry trade should be positively correlated with the degree of similarity between countries' capital-labor ratios. Loertscher and Wolter (1980) use differences in per capita income as a proxy for differences in resource endowments, and confirm the correlation using a cross-section for a single year. Helpman (1987) uses a more extended data set to confirm the proposition over a number of years; he also shows that as the industrial countries became more similar over time, the relative importance of intra-industry trade grew, just as the model would suggest.

The Helpman-Krugman model was also tested by Lynde (1992). He performed an econometric analysis of the trade flows of 52 countries for the year 1980, with the aim of comparing the accuracy of the predictions of the Helpman-Krugman model. Lynde's findings were very consistent with the predictions of the Helpman-Krugman model.

Havrylyshyn and Civan (1983) confirm a proposition that intra-industry trade is likely to be more common in the trade between developed countries than in the trade between developing countries, on the assumption that developed countries produce more differentiated products.

Greenaway and Milner (1986) have surveyed the literature on the testing of hypotheses concerning intra-industry trade. They suggest that the hypotheses can be classified in three groups. The first group of studies identifies country-specific characteristics that influence the

\footnotetext{
${ }^{36}$ Loertscher and Wolter (1980) use the data for the OECD countries; Lundberg (1982) for Sweden; Greenaway (1983) for the U.K.; Tharakan (1986) for Benelux; and Balassa (1986) for the U.S..
} 
extent of intra-industry trade ${ }^{37}$. The empirical results show that the extent of intra-industry trade is positively correlated with country characteristics. The general consistency of the signs and the significance levels of the coefficients give support for the country-specific hypotheses.

The second group of studies has emphasized industry-specific determinants of intraindustry trade relating to scale economies, product differentiation, and imperfect competition ${ }^{38}$. Greenaway and Milner conclude that there are some systematic inter-industry characteristics of intra-industry trade, and varying degrees of support for the hypotheses, but country characteristics seem to be more important than industry characteristics in explaining intra-industry trade.

The final group of empirical studies analyzed policy-based hypotheses relating to tariffs, non-tariff barriers, and economic integration ${ }^{39}$. Greenaway and Milner conclude that there is no consistent empirical evidence that variations in intra-industry trade can be explained by policy interventions.

A more recent study is Kim and Oh (2001). From the cross-sectional analysis using 19701994 data, results are obtained that support the following three empirical hypotheses: The share of intra-industry trade will be large: (a) if the two economies are of similar size, (b) if the capitallabor endowment ratio of both countries is similar, and (c) if the total size of the two economies is large.

\footnotetext{
${ }^{37}$ Loertscher and Wolter (1980), Havrylyshyn and Civan (1983), Balassa (1986), and Globerman and Dean (1990).

${ }^{38}$ Culem and Lundberg (1983), Greenaway and Milner (1984), Balassa (1986), Marvel and Ray (1987), Ray (1991), Hamilton and Kniest (1991), Lundberg (1992), and Clark (1993).

39 Balassa (1986), Bergstrand (1983), Havrylyshyn and Civan (1983), Toh (1982), Caves (1981), and Loertscher and Wolter (1980).
} 


\section{Data and Methodology}

\subsection{Data}

Trade data of 2002 for 24 developed countries are included in the analysis with per capita incomes of $\$ 10,000$ or higher. In the order of decreasing per capita GNP, these countries are Luxembourg, Norway, USA, Switzerland, Japan, Denmark, Ireland, Iceland, United Kingdom, Netherlands, Sweden, Finland, Austria, Canada, Germany, Belgium, France, Australia, Italy, Israel, Spain, New Zealand, Portugal, and Greece.

The investigation covers 44 three-digit industry groups which belong to Section 7 of the Standard International Trade Classification (SITC) system. The three-digit SITC classification is typically considered an 'industry' for econometric purposes. Import and export data with a value of $\$ 50,000$ or more are included in the analysis. Trade statistics are taken from World Trade Annuals of the United Nations Statistics Division. GNP data are from the International Financial Statistics. Per capita GNP data is from IMF, World Economic Outlook Database. GNP in current prices is used as a proxy variable for the size of the economies, and per capita GNP is used for the capital-labor endowment ratio.

Section 7, i.e. "Machinery and Transport Equipment" includes technological goods which involve production technologies that are not universally available and change relatively frequently. For most industrialized countries, it has been known that intra-industry trade occurs in these SITC industry groups. These include those industries which share the typical characteristics of industries involved in intra-industry trade, such as product differentiation, economies of scale, and rapid innovation. Some industry groups in Section 7 include engines, turbines, motors, power generating machinery, tractors, textile and leather machinery, printing machinery, heating-cooling equipment, non-electrical machinery, office machines, television receivers, radio broadcast 
receivers, telecom equipment, transistors, road motor vehicles, railway vehicles, aircraft, and ships.

The total number of observations is $12,144\left(={ }_{24} \mathrm{C}_{2}(=276)\right.$ country combinations $\mathrm{x} 44$ SITC categories); but in $18 \%$ of cases neither exports nor imports exist in bilateral trade flows, so intra-industry trade index is not defined and these observations are excluded from the analysis. So then we have a total of 9976 observations.

\subsection{Grubel-Lloyd Index and Aggregation Problem}

The Grubel-Lloyd (hereafter, GL) index is the central measure of intra-industry trade and almost all of the empirical studies have used this index; so at this research, this measure will be employed, expressed as

$$
I I T_{i}=\left[1-\left(\left|X_{i}-M_{i}\right| /\left(X_{i}+M_{i}\right)\right)\right]
$$

where $X_{i}$ is exports of industry $i, M_{i}$ is imports of industry $i,\left|X_{i}-M_{i}\right|$ is net trade, $\left(X_{i}+M_{i}\right)$ is total trade, $i=1, \ldots, n$ and $0 \leq I I T_{i} \leq 1$. An index value of 0 would indicate complete inter-industry trade. Either the value of exports or imports would be zero. Higher index values are associated with greater intra-industry trade as a proportion of total trade, with an index value of 1 indicating equality between exports and imports.

When Eq. (1) is aggregated across industries to form a weighted average intra-industry trade measure, the resulting index will not attain the desired maximum value of 1 if the country's total commodity trade is imbalanced. The greater is the imbalance, the smaller will be the share of intra-industry trade. Based on this finding, GL (1975) argue that this measure of intra-industry trade must be adjusted for the aggregate trade imbalance. 
According to Vona (1991), and Kol and Mennes (1989), measures of intra-industry trade should not be corrected for the overall trade imbalance. Vona (1991) argues that the argument for the need of correction is theoretically poor and leads to unreliable adjustment procedure and he uses arithmetic examples to establish the superiority of GL's uncorrected index over corrected indices which appear in the literature. Based on these, the proposed study will employ GL's uncorrected measure of intra-industry trade $e^{40}$.

\subsection{Estimation Techniques}

In estimating the determinants of intra-industry trade, most authors use a linear or log-linear function by ordinary least squares (e.g., Toh, 1982; Lundberg, 1982; and Tharakan, 1986). We will use OLS and truncated regression. We have truncated data since we don't allow our observations to be less than 0 or greater than 1 ; that is the sample is drawn from a restricted part of the population. When using OLS, Newey-West estimator is used which provides a covariance matrix that is consistent in the presence of both heteroskedasticity and autocorrelation.

\subsection{Methodology}

In following, we state the hypotheses that have been tested in our paper and define the explanatory variables used in the estimation. We also refer to the theoretical literature where the hypotheses originate.

It is hypothesized that the extent of intra-industry trade between any pair of countries will be: (1) positively correlated with average per capita incomes, representing the extent of demand for differentiate products (Linder, 1961);

\footnotetext{
${ }^{40}$ Ballance et al. (1992), Lundberg (1992), Hamilton and Kniest (1991), and Globerman and Dean (1990) are examples of recent studies that do not correct intra-industry trade indices for the overall trade imbalance. Bergstrand (1990) uses the GL adjusted index. The methodology and rationale for the adjustment is discussed in Bergstrand (1983: pp. 206-209).
} 
(2) negatively correlated with differences in per capita incomes, representing differences in demand structures (Linder, 1961) and / or differences in resource endowments (Dixit and Norman, 1980; Helpman, 1981);

(3) positively correlated with average country size, indicating the possibilities for increasing the variety of differentiated products manufactured under economies of scale (Lancaster, 1980); and

(4) negatively correlated with differences in country size, indicating differences in their ability to manufacture differentiated products (Dixit and Norman, 1980; Helpman, 1981).

In testing hypotheses (1) to (4), per capita income has been represented by GNP per capita and country size by GNP. Instead of taking the absolute values of inter-country differences in per capita incomes and size, following Balassa (1986), we have used a measure indicating relative differences that takes values between 0 and 1 . This measure is superior to utilizing the absolute values of the differences, which are affected by the magnitudes of the particular country characteristics in the different countries. The relative difference measure is shown in (4),

$$
I N E Q=1+[w \ln w+(1-w) \ln (1-w)] / \ln 2, \text { where }
$$

$w$ refers to the ratio of a particular country characteristic in country $j$ to the sum of this characteristic in country $j$ and partner country $k^{41}$

It is hypothesized that the extent of intra-industry trade between any pair of countries will be: (5) negatively correlated with the distance between them, representing the availability and the cost of information necessary for trading differentiated products; and

\footnotetext{
${ }^{41}$ This measure is symmetrical with respect to country characteristics; it is not affected by a change in the unit of measurement, and it is a convex function of $w$.
} 
(6) positively correlated with the existence of common borders, indicating the possibilities for intra-industry trade in response to locational advantages (Grubel and Lloyd, 1975).

In testing hypothesis (5), distance has been measured in terms of miles between the centers of geographical gravity for each pair of countries. In turn, the existence of common borders (hypothesis 6) has been represented by a dummy variable.

It is hypothesized that the extent of intra-industry trade between any pair of countries will be: (7) positively correlated with participation in regional integration schemes, including the European Union and the North American Free Trade Association, indicating the possibilities of intra-industry trade in the framework of regional integration schemes.

(8) positively correlated with the use of a common language, including English, German, French, and Scandinavian (Danish, Finnish, Norwegian, and Swedish).

Hypothesis (7) has been tested by introducing dummy variables to represent participation in the European Union (EU) and the North American Free Trade Association (NAFTA). In testing hypothesis (8), dummy variables are introduced for each of the languages for any pair of countries where the same language is spoken. 


\section{The Model}

\subsection{The Theory}

This section summarizes the theoretical model; the following framework is similar to that of Helpman (1981), Helpman and Krugman (1985, ch.7), and Kim and Oh (2001).

\subsubsection{Closed Economy}

Consider a $2 \times 2 \times 2$ economy in which capital and labor are the only factors of production, and output consists of two goods; the differentiated product $X$, and the homogeneous product $Y$. There is a perfectly competitive market for $Y$. Monopolistic competition and economies of scale prevail in industry $X$.

Consumers are assumed to maximize Cobb-Douglas utility functions,

$$
\left.U=\left(\sum_{i=1}^{n} x_{i}^{\rho}\right)^{(\alpha / \rho)} y^{(1-\alpha)}\right) \quad 0<\alpha<1,0<\rho<1
$$

where $x_{i}$ and $y$ are the consumption levels for the respective products and $n$ is the number of differentiated products in the $X$ industry, $\alpha$ and $\rho$ are constants, and $\alpha$ is the share of total consumption given to the consumption of $X$. Cost functions for $\mathrm{X}$ and $\mathrm{Y}$ are shown in Equations 4 and 5. The first cost function is homogeneous of degree one and the second cost function is a homothetic function with economies of scale.

$$
\begin{aligned}
& C(w, r, Y)=C^{Y}(w, r) Y \\
& C(w, r, X)=C^{X}(w, r) e(X)
\end{aligned}
$$

Here $w, r$ are wage and rent respectively, $e(X)$ is a differentiable decreasing function, which implies the economies of scale. $C_{y}($.$) and C_{x}($.$) are differentiable concave functions. From the$ above presumptions, we obtain the following equilibrium conditions: 


$$
\begin{aligned}
& 1=C^{Y}(w, r) \\
& P_{S}=C^{X}(w, r) \\
& a_{L X}(w, r) S+a_{L Y}(w, r) Y=L \\
& a_{K X}(w, r) S+a_{K Y}(w, r) Y=K \\
& \frac{S}{Y}=\left(\frac{\alpha}{1-\alpha}\right)\left(\frac{1}{P_{S}}\right) \\
& \frac{1}{\rho}=\left(\frac{e(X)}{e(X) X}\right) \\
& \frac{P_{X} X}{e(X)}=P_{S} \\
& n . e(X)=S
\end{aligned}
$$

The homogeneous product $Y$, is taken to be the numeraire $\left(P_{Y}=1\right) . S$ is an auxiliary variable defined in Equation 13 for simple calculation, after Helpman (1981). $P_{S}$ is the price of $S . L$ and $K$ are the capital and labor endowment of the economy. The model consists of eight equations, where Equations 6-10 are identical to the Heckscher-Ohlin model. From these five equations, the equilibrium values of the five endogenous variables $w, r, P_{S}, S, Y$ are obtained. The solutions for $X, P_{S}, n$ are obtained from Equations 11-13, leading to solutions for all eight variables. 


\subsubsection{Integrated Economy}

Now consider a two-country model with identical production functions and utility functions. Free trade between the countries equalizes the prices of products and factors of production. Thus, the integrated economy under free trade shows the same characteristics as the closed economy. The degree of difference in factor proportions is defined as in Equation 14.

$$
D^{H}=\frac{K^{H}}{K}-\frac{L^{H}}{L} \quad-1 \leq D^{H} \leq 1
$$

Here, the superscripts $H$ and $F$ denote the home and foreign country, respectively. $L$ and $K$ are world labor and capital, and $D^{H}$ is the difference between the factor endowments of the countries. $D^{H}>0$ implies that the home country is capital abundant and $D^{H}<0$ means that the home country is labor abundant. From $L=L^{H}+L^{F}$ and $K=K^{H}+K^{F}, D^{F}=-D^{H}$. If $g^{H}$ is regarded as the share of the home economy in the integrated economy,

$$
g^{H}=\frac{I^{H}}{I}=\frac{w L^{H}+r K^{H}}{L}
$$

where $I$ is the total income of the integrated economy and $I^{H}$ is the income of the home country. For $I^{F}=I-I^{H}, g^{F}=1-g^{H}$. Using Equations 14 and 15, equations 16 and 17 are obtained.

$$
\begin{aligned}
& L^{H}=L\left(g^{H}-\theta_{K} D^{H}\right) \\
& K^{H}=K\left(g^{H}+\theta_{L} D^{H}\right)
\end{aligned}
$$

Note that $\theta_{L}+\theta_{K}=1$ and $\theta_{i}(i=L, K)$ is the share of factor $i$ in total income. In the factor price equalization area, there is a one-to-one relationship between the factor price and product price, and the prices of the goods are given as constant in the integrated economy. Therefore, in equilibrium, factor prices would not change, even if the factors were reallocated. If there is no change in factor prices, there is no change in $a_{i j}(\mathrm{i}=L, K ; j=X, Y)$. Therefore, $a_{i j}$ is regarded as 
constant once the integrated economy is in equilibrium. Now, rearranging Equations 8 and 9, Equations 18 and 19 are obtained.

$$
\begin{aligned}
& Y=b_{K X} L-b_{L X} K \\
& S=-b_{K Y} L+b_{L X} K
\end{aligned}
$$

Here, $\left.b_{i j}=a_{i j} /|A|, \mathrm{i}=K, L ; j=X, Y\right)$, and $|A|=a_{L X} a_{L Y}\left(k_{X}-k_{Y}\right)$ and $k_{X}, k_{Y}$ denote capital-labor ratio in the production (factor intensity). If $X$ is capital intensive goods, $|A|$ is positive because $k_{X}>k_{Y}$

In the integrated economy, the goods prices and factor prices are identical between the two countries and hence $a_{i j}$. Therefore, substituting $L^{H}, K^{H}$ of Equations 18 and 19 into equations 20 and $21, Y^{H}$ and $S^{H}$ can be solved as follows.

$$
\begin{aligned}
& Y^{H}=Y \cdot g^{H}-\phi_{Y} D^{H} \\
& S^{H}=S \cdot g^{H}+\phi_{S} D^{H}
\end{aligned}
$$

Here $\phi_{Y}=b_{K X} \theta_{K} L+b_{L X} \theta_{L} K, \phi_{S}=b_{K Y} \theta_{K} L+b_{L Y} \theta_{L} K$. If we put a superscript $F$ instead of $H$, we obtain the values for the foreign country, $Y^{F}$ and $S^{F}$. Now we know that the production level in each country depends on $b_{i j}(\mathrm{i}=L, K ; j=X, Y)$, the relative size of the economy, $g$, and the difference in factor abundance, $D$. Here, since $b_{i j}$ depends on $a_{i j}$, which is given by the characteristics of the production function and the utility function, we say that the equilibrium production in a country is determined by $g$ and $D$. 


\subsubsection{Trade Volume and Trade Pattern}

Consider two types of trade; inter-industry trade and intra-industry trade. If sector $X$ produces differentiated products, we see a two-way flow of good $X$, which implies intra-industry trade. Note that the home residents consume a proportion $g^{H}$ of world output, since preferences in the two countries are assumed to be identical. Therefore, if the home country is a capital abundant country $\left(D^{H}>0\right)$ and $X$ is a capital intensive good, the home country will export $X$ and import $X$ and $Y$. Here, the sum of net exports of $X$ and the imports of $Y$ will give the value of inter-industry trade $(H)$. Assuming balance trade, the total value of exports of $X$ is equal to the total value of imports of $X$ and $Y$. From the fact that inter-industry trade will be two times as large as net exports of $X$, Equation 24 is obtained.

$$
H=2\left(P_{S} S^{H}-g^{H} P_{S} S\right) \quad D^{H} \geq 0
$$

The intra-industry trade $(G)$ is defined as in Equation 25;

$$
G=2 \min (E X, I M)
$$

where $E X$ and $I M$ are the values of exports and imports, respectively. Under the assumption that $X$ is a capital intensive good, if the home country is capital abundant $\left(D^{H}>0\right)$, we have net exports of $X(E X>I M)$. Thus, intra-industry trade in sector $X$ will be shown as Equation 24 .

$$
G=2 I M=2 g^{H} P_{S} S^{F} \quad D^{H} \geq 0
$$

Now total volume of trade is expressed as

$$
V T=H+G
$$

Putting Equations 20 and 21 into Equations 22, 24, 25 the following system of equations (under $D^{H} \geq 0$ ) is obtained: 


$$
\begin{gathered}
\left.H=2 P_{S} \phi_{S}\right) D^{H} \\
G=2 P_{S} S\left(g^{F} g^{H}\right)-2 P_{S} \phi_{S}\left(g^{H} D^{H}\right) \\
V T=2 P_{S} S\left(g^{F} g^{H}\right)+2 P_{S} \phi_{S}\left(g^{F} D^{H}\right)
\end{gathered}
$$

Now, consider an IIT index, $B$, as the ratio of IIT to total trade

$$
B=\frac{G}{V T}
$$

Substituting Equations 27 and 28 into Equation 31, one obtains

$$
B=\frac{S\left(g^{F} g^{H}\right)-\phi_{S}\left(g^{H} D^{H}\right)}{S\left(g^{F} g^{H}\right)+\phi_{S}\left(g^{F} D^{H}\right)}
$$

Here, three interesting relationships are found. First, if $D=0, B$ will be one. This implies that if relative factor endowments of the two countries are identical, the IIT index is one, regardless of the size of the integrated economy. Second, $B$ increases as the absolute value of $D$ becomes smaller, given $g$. What this means is that given the size of the integrated economy, the IIT index will increase as the relative factor endowments of the two countries become more similar. Third, the IIT index increases as the sizes of the two economies become similar, given the relative factor endowments. 


\subsection{Results of the Empirical Analysis}

To test the hypotheses which are stated in Section 3.4, the following equation is estimated:

$$
\begin{aligned}
& I I T=\beta_{1}+\beta_{2} \text { AveGNP }+\beta_{3} \text { AveGNP/cap }+\beta_{4} \text { DifGNP }+\beta_{5} \text { DifGNP } / \text { cap }+ \\
& \beta_{6} \text { Dislance }+\beta_{7} \text { Borders }+\beta_{8} E U+\beta_{9} N A F T A+\beta_{10} \text { English }+\beta_{11} \text { German }+ \\
& \beta_{12} \text { French }+\beta_{13} \text { Scandinavian }+\varepsilon,
\end{aligned}
$$

where IIT is the bilateral Grubel-Lloyd intra-industry trade index calculated for each pair of countries using the weighted average of the 44 three-digit SITC industry grouping in SITC 7. AveGNP is the variable indicating the average country (economy) size of any pair of countries, AveGNP/cap is the average of the per capita incomes of any pair of countries, DifGNP is the difference in country (economy) size between any pair of countries, DifGNP/cap is the difference in per capita incomes of any pair of countries, Distance is the distance between any pair of countries, Borders is a dummy variable which equals one if there is a common border between any pair of countries, $E U$ is a dummy variable which equals one if the two countries participate in EU, NAFTA is a dummy variable which equals one if the two countries participate in NAFTA, English is a dummy variable which equals one if the two countries use English as a common language, German is a dummy variable which equals one if the two countries use German as a common language, French is a dummy variable which equals one if the two countries use French as a common language, Scandinavian is a dummy variable which equals one if the two countries use Scandinavian (Danish, Finnish, Norwegian, and Swedish) as a common language.

Table 1 reports the results for both regressions; OLS and truncated regression: 
Table 1

Estimation of Intra-Industry Trade in a Multi-Country and Multi-Industry Framework

(OLS and Truncated regression with robust standard errors)

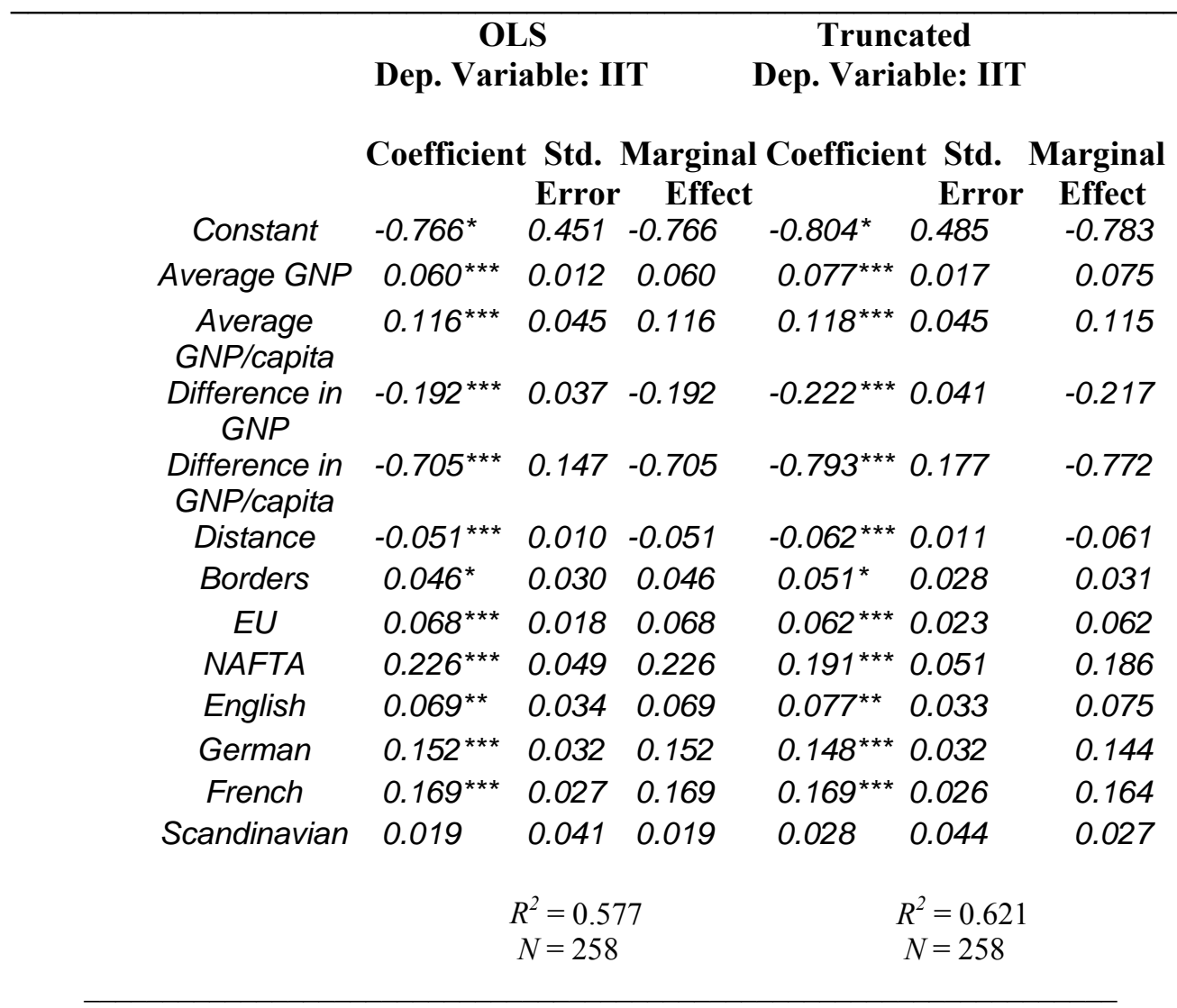

***Significant at the $1 \%$ level

**Significant at the $5 \%$ level

*Significant at the $10 \%$ level

The empirical results support the hypotheses put forward in Section 3.4 of the paper. As expected, the extent of intra-industry trade is positively correlated with average GNP, average GNP/capita, and the existence of a common border; and it is negatively correlated with differences in GNP and GNP/capita, and distance. All the variables are highly significant statistically. Moreover, the EU and NAFTA dummy variables have the expected positive sign and are highly significant statistically. In turn, the regression coefficients of the language dummy variables have a positive sign, but their level of statistical significance varies. The German, and French language variables 
are significant at the $1 \%$ level, the English variable is significant at the 5\% level, while the Scandinavian language variable is not significant at even the $10 \%$ level. The coefficient of determination is 0.577 in the OLS regression and it is 0.621 in the truncated regression.

A further question concerns the relative importance of the individual variables in explaining variations in the extent of intra-industry trade. In the following table we report the increase of the coefficient of determination resulting from the inclusion of an explanatory variable, given the use of all the other variables, in regard to intra-industry trade among all countries.

Table 2

Comparison of the Coefficients of Determination in Different Models

OLS Truncated

Dep. Variable: IIT Dep. Variable: IIT

\begin{tabular}{cccc}
\hline $\mathbf{R}^{2}$ & Difference & $\mathbf{R}^{2}$ & Difference \\
\hline & & & \\
0.577 & - & 0.621 & - \\
0.402 & 0.175 & 0.452 & 0.169 \\
0.496 & 0.081 & 0.526 & 0.095 \\
0.529 & 0.048 & 0.569 & 0.052 \\
0.538 & 0.039 & 0.586 & 0.035 \\
0.555 & 0.022 & 0.595 & 0.026 \\
0.559 & 0.018 & 0.598 & 0.023 \\
0.560 & 0.017 & 0.602 & 0.019 \\
0.560 & 0.017 & 0.603 & 0.018 \\
0.568 & 0.009 & 0.608 & 0.013 \\
0.569 & 0.008 & 0.609 & 0.012 \\
0.571 & 0.006 & 0.612 & 0.009 \\
0.573 & 0.004 & 0.613 & 0.008 \\
0.573 & 0.004 & 0.615 & 0.006 \\
0.576 & 0.001 & 0.618 & 0.003 \\
0.576 & 0.001 & 0.620 & 0.001
\end{tabular}

Model 1: With all variables

Model 2: Average GNP excluded

Model 3: Difference in GNP excluded

Model 4: Difference in GNP/capita excluded

Model 5: Distance excluded

Model 6: EU\&NAFTA excluded

Model 7: All Languages excluded

Model 8: $E U$ excluded

Model 9: Average GNP/capita excluded

Model 10: English excluded

Model 11: German excluded

Model 12: NAFTA excluded

Model 13: Borders excluded

Model 14: French excluded

Model 15: Scandinavian excluded

Model 16: Industry excluded

OI Dep. Variable: IIT 
The results show that the variables Average GNP and Difference in GNP are the country characteristics that contribute the most to the explanatory power of the regression equations, followed by Difference in GNP / capita, Distance, EU and NAFTA together, all Languages, EU, and Average GNP / capita. By contrast, introduction of the language variables adds little to the explanatory power of the equations.

At this point it is appropriate to ask whether the results might differ if industry variables such as degree of product differentiation and degree of product standardization were introduced into the estimation. This question has been addressed in Balassa and Bauwens (1987) and it is shown that differences in the values of the regression coefficients for country characteristics in no case attain $2 \%$. At the same time, the statistical significance of the regression coefficients is hardly affected and the coefficient of determination changed only slightly from 0.436 to 0.443 by adding industry characteristics. 


\section{Conclusions}

This paper has tested various hypotheses about the determinants of intra-industry specialization in manufactured goods, including common and specific country characteristics. The study covers 24 countries exporting manufactured goods; calculations have been made for bilateral trade flows among all the 24 countries.

The hypotheses put forward in the theoretical literature in regard to common country characteristics are generally confirmed by the empirical results. Thus, the extent of intra-industry trade is positively correlated with average income levels, average country size, and the existence of common borders and it is negatively correlated with income inequality, inequality in country size, and distance. All the variables are highly significant.

We also found that the extent of intra-industry trade and participation in the EU, and the NAFTA are positively correlated, with all the coefficients being highly significant in the relevant equations. Also, the language variables have the expected positive sign whenever they are statistically significant, which is the case in most instances. 


\section{References}

Balassa, B. (1986) 'The determinants of intra-industry specialization in United States trade', Oxford Economic Papers, 38: 220-233.

Balassa, B. and Bauwens, L. (1987) 'Intra-industry specialization in a multi-country and multi industry framework', The Economic Journal, 97: 923-939.

Bergstrand, J.H. (1983) 'Measurement and determinants of intra-industry international trade', in P.K.M. Tharakan, ed., Intra-Industry Trade: Empirical and Methodological Aspects. Amsterdam: North Holland.

Bergstrand, J.H. (1990) 'The Heckscher-Ohlin-Samuelson model, the Linder hypothesis and the determinants of bilateral intra-industry trade', The Economic Journal, 100: 1216-1229.

Bhagwati, J.N. and Davis, D. (1994) 'Intra-industry trade: Issues and theory', discussion paper no. 1695, Harvard University.

Breusch, T.S. and Pagan, A.R. (1979) 'A simple test for heteroscedasticity and random coefficient variation', Econometrica, 47: 1287-1294.

Caves, R.E. (1981) 'Intra-industry trade and market structure in the industrial countries', Oxford Economic Papers, 33: 203-223.

Clark, D.P. (1993) 'Recent evidence on determinants of intra-industry trade', Weltwirtschafliches Archiv, 129: 332-344.

Culem, C. and Lundberg, L. (1983) 'The product pattern of intra-industry trade: Stability among countries and over time', Weltwirtschafliches Archiv, 122: 113-130.

Dixit, A. and Norman, V. (1980) Theory of International Trade: A Dual, General Equilibrium Approach. Cambridge: MIT Press. 
Ethier, W.J. (1982) 'National and international returns to scale in the modern theory of international trade', The American Economic Review, 72: 389-405.

Fukasaku, K. (1992) 'Economic regionalization and intra-industry trade: Pacific-Asian perspective', technical papers no. 53, OECD Development Centre.

Globerman, S. and Dean, J.W. (1990) 'Recent trends in intra-industry trade and their implications for future trade liberalization', Weltwirtschafliches Archiv, 126: 25-49.

Greenaway, D. (1983) International Trade Policy: From Tariffs to the New Protectionism. London: Macmillan.

Greenaway D. and Milner, C.R. (1984) ‘A cross section analysis of intra-industry trade in the U.K.', European Economic Review, 25: 319-344.

Greenaway, D. and Milner, C.R. (1986) The Economics of Intra-Industry Trade. Oxford: Blackwell.

Grubel, H.G. and Lloyd, P.J. (1975) Intra-Industry Trade. London: Macmillan.

Gunasekera, H.D. (1989) 'Intra-industry specialization in production and trade in newly industrialized countries: A conceptual framework and some empirical evidence from East Asia', World Development, 17: 1279-1287.

Hamilton, C. and Kniest, P. (1991) 'Trade liberalization, structural adjustment, and intra industry trade: A note', Weltwirtschaftliches Archiv, 127: 356-367.

Havrylyshyn, O. and Civan, E. (1983) 'Intra-industry trade and the stage of development: A regression analysis of industrial and developing countries', in P.K.M. Tharakan, ed., Intra Industry Trade: Empirical and Methodological Aspects. Amsterdam: North Holland. 
Helpman, E. (1981) 'International trade in the presence of product differentiation, economies of scale, and monopolistic competition: A Chamberlinian-Heckscher-Ohlin approach', Journal of International Economics, 11: 305-340.

Helpman, E. (1987) 'Imperfect competition and international trade: Evidence from fourteen industrial countries', Journal of the Japanese and International Economies, 1: 62-81.

Helpman, E. and Krugman, P.R. (1985) Market Structure and Foreign Trade: Increasing Returns, Imperfect Competition, and the International Economy. Cambridge: MIT Press.

Helpman, E. and Krugman, P.R. (1989) Trade Policy and Market Structure. Cambridge: MIT Press.

Kim, T. and Oh, K. (2001) 'Country size, income level and intra-industry trade', Applied Economics, 33: 401-406.

Kol, J. and Mennes, L.B.M. (1989) 'Corrections for trade imbalance: A survey', Weltwirtschaftiches Archiv, 125: 703-717.

Krugman, P.R. (1979) 'A model of innovation, technology transfer, and the world distribution of income', Journal of Political Economy, 87: 253-266.

Krugman, P.R. (1981) 'Intra-industry specialization and the gains from trade', Journal of Political Economy, 89: 959-973.

Laird, S. (1981) 'Intra-industry trade and the expansion, diversification and integration of the trade of the developing countries', Trade and Development: A UNCTAD Review, 3: 79-101.

Lancaster, K. (1979) Variety, Equity, and Efficiency. New York: Columbia University Press.

Lancaster, K. (1980) 'Intra-industry trade under perfect monopolistic competition', Journal of International Economics, 10: 151-175. 
Lee, Y.S. (1987) 'Intra-industry trade in the Pacific Basin', International Economic Journal, 1: 75-89.

Linder, S.B. (1961) An Essay on Trade and Transformation. New York: Wiley.

Loertscher, R. and Wolter, F. (1980) 'Determinants of intra-industry trade: Among countries and across industries', Weltwirtschaftliches Archiv, 116: 280-293.

Lundberg, L. (1982) 'Intra-industry trade: The case of Sweden', Weltwirtschafliches Archiv, 118: 302-316.

Lundberg, L. (1992) 'The structure of Swedish international trade and specialization: Old and new explanations', Weltwirtschafliches Archiv, 128: 266-287.

Lynde, M.R. (1992) 'Testing an imperfect competition trade model', in M.G. Dagenais and P.A. Muet (eds), International Trade Modelling. New York: Chapman and Hall.

Marvel, H.P. and Ray, E.J. (1987) 'Intra-industry trade: Sources and effects on protection', Journal of Political Economy, 95: 1278-1291.

Ray, E.J. (1991) 'U.S. protection and intra-industry trade: The message to developing countries', Economic Development and Cultural Change, 40: 169-187.

Tharakan, P.K.M. (1986) 'The intra-industry trade of Benelux with the developing world', Weltwirtscaftliches Archiv, 12: 131-149.

Toh, K. (1982) 'A cross section analysis of intra-industry trade in U.S. manufacturing industries', Weltwirtschafliches Archiv, 118: 281-301.

Vona, S. (1991) 'On the measurement of intra-industry trade: Some further thoughts', Weltwirtschafliches Archiv, 127: 678-700. 


\section{Chapter 5. Summary and Conclusions}

This dissertation provides three essays on strategic trade policies, intra-industry trade, and income convergence. The assumptions of constant returns to scale and perfect competition are often violated in the real world. Traditional trade theory based on perfect competition does not effectively explain phenomena such as intra-industry trade and the high volume of trade between similar countries. Moreover, such models failed to successfully integrate some important policy related considerations, such as increasing returns to scale, learning-by-doing, $\mathrm{R} \& \mathrm{D}$, and interfirm strategic rivalries. Effective analysis of these topics requires imperfect competition, which together with increasing returns to scale is one of the main characteristics of many of today's industries, especially of those in the industrialized countries. As new theories of imperfectly competitive markets have developed, game-theoretic approach of strategic trade policy began to emerge in the early 1980's.

As a strategic trade policy instrument, an export subsidy used by the foreign government could be "countervailed" by a domestic import tariff. The interesting point about these countervailing effects is that they do not eliminate incentives to use active strategic trade policy, and the policy equilibrium normally implies positive subsidies and tariffs.

It may be of a particular interest to integrate the strategic trade policy with the hierarchical games in firm theory. Traditional economic theory considers firms as economic agents with the single objective of profit maximization. Some have criticized this as being simplistic, arguing that real firms may have a different goal. Several theories have suggested that large firms are more concerned with maximizing revenues or market shares rather than profits. Recent advances in international trade theory emphasize strategic behavior among firms of 
different countries and its implication for trade policy. With the separation of ownership, management, and workers various incentive structures exist within a modern corporation. In order to correctly assess the policy intervention in international trade, it is important to understand how trade policies affect intra-firm incentives and vice versa.

It is generally argued that a proper analysis of the firm's objective function should be based on the analysis of the owner-manager relationship. A manager's objective depends on the structure of the incentives that his owner sets to motivate him. Owners often index managerial compensation to profits, sales, output, quality, and some other variables. Even if the owners want to maximize profits, the incentive system they design may imply managerial incentives which are different from profit maximization. The principal (firm owner) can distort the incentives of his agents (firm managers) in order to affect the outcome of the competition between his agent and competing agents. In general, the owner of a firm will adjust his managers' incentives in such a way that it will cause rival agents to change their behavior in favor of that firm.

Chapter 2 is concerned with strategic managerial delegation and its implications for international trade policy. Corporate firms, with separation of management and ownership, compete in international markets. We ask how trade policy affects the incentive to managers, which in turn affects the impact of trade policy on prices and quantities. Our paper combines the models of Collie (1994) and Sklivas (1987) in a single integrated analytical framework. The integrated model has a modest contribution to the literature by investigating the strategic trade policies under duopoly in a multistage game with endogenous timing of trade policy when the ownership and the management are separated for each firm. 
In Chapter 2, trade policy is modeled as a multi-stage game and the timing of trade policy decisions is endogenous. At the beginning of the game, stage zero, home and foreign governments independently and simultaneously choose whether to set trade policy at stage one or at stage two. Then, at the chosen stage, each government sets its trade policy to maximize its national welfare. The home government uses an import tariff to shift rent from the foreign firm and a production subsidy to correct the domestic distortion due to imperfect competition. The foreign government uses an export subsidy to shift profits from the home firm to the foreign firm. If, at stage zero, both governments choose to set trade policy at the same stage of the game, then the outcome will be a simultaneous-move trade policy game. If the home [foreign] government chooses to move at stage one and the foreign [home] government chooses to move at stage two, then the outcome will be a Stackelberg game where the home [foreign] government is the Stackelberg leader. At stage three the owners will simultaneously write and announce contracts with their managers that specify how they will be rewarded. Finally, the managers will simultaneously choose their firms' outputs. The appropriate solution for this multistage game is the subgame perfect equilibrium, which is obtained by applying the Nash equilibrium to all the stages of the game by the process of backward induction.

The results show that in the subgame perfect equilibrium of the trade policy game, the home government sets its tariff and production subsidy at stage one and the foreign government sets its export subsidy at stage two. By setting trade policy at stage one the home government commits itself to a lower tariff and production subsidy than in the Nash equilibrium of the simultaneous-move game, and this encourages the foreign government to use a larger export subsidy than in the Nash equilibrium of the simultaneous-move game. As a result both countries are better off when the home government is the Stackelberg leader than in the simultaneous-move game. The home country benefits from a larger foreign export subsidy, and the foreign country 
gains from facing a lower tariff and production subsidy. The conclusion for trade policy is that imperfect competition does not provide an economic rationale for countervailing duties since the home country should commit not to use countervailing duties. When compared to those of Collie (1994), our results show that home and foreign welfares are higher, home firm's profits are lower, and foreign firm's profits are higher in each of the three games, i.e. simultaneous-move trade policy game, Stackelberg game when the home government is the Stackelberg leader, and Stackelberg game when the foreign government is the Stackelberg leader.

Chapter 3 analyzes the relationship between international trade and income convergence among countries by focusing on groups of countries comprising major trade partners. The subject of convergence of economic growth is one of the most important issues in modern economics. In a world in which countries exchange goods, factors, and ideas; international linkages are what drive any convergence process. Free trade in goods can equalize factor prices across countries according to the factor-price-equalization theorem; international flows of factors can lead to convergence of endowments and factor prices; and international flows of technology can cause convergence of factor prices as well.

In neoclassical growth models a country's per capita growth rate tends to be inversely related to its starting level of per capita income. In particular, if countries are similar with respect to structural parameters for preferences and technology, then poor countries tend to grow faster than rich countries. That is, it is a prediction of neoclassical economic growth theory that differences in per capita income across different economies will tend to decrease or disappear over time. This is broadly referred to as the convergence hypothesis. 
Though there is evidence of income convergence among some of the wealthy countries (Baumol, 1986; Baumol et al., 1989), it is not obvious why some subsets of these countries exhibit greater convergence than others, while other subsets of countries display no convergence tendencies at all. Chapter 3 analyzes this issue from the perspective of trade's contribution to the process. It examines the relationship between international trade and income convergence among countries by focusing on groups of countries forming major trade partners.

The analysis includes the 1971-2002 income and trade data of 24 developed countries ${ }^{42}$ with per capita incomes of $\$ 10,000$ or higher in 2002 . The first step is to determine each country's primary trade partners and to create trade groups using the intra-industry trade shares of the total trade between countries. Having formed the trade groups, the behavior of each group's income differentials over time is examined for a significant evidence of convergence within them. The results show that majority of these intra-industry trade-based groups exhibit significant convergence. When the trade groups are formed according to the total trade between the countries rather than intra-industry trade, we see a significant decrease in the number of the groups which exhibit income convergence.

Then, the robustness and sensitivity of the results are examined from a number of different perspectives. To test whether any random grouping of these same countries might produce similar results, the 24 source countries are grouped into their many different possible subgroups and their convergence coefficients are estimated. To test whether convergence within groups might be towards one country that is common to most of the groups, the major trade partner of the countries is removed from each of the groups, the new convergence coefficients are

\footnotetext{
${ }^{42}$ Australia, Austria, Belgium, Canada, Denmark, Finland, France, Germany, Greece, Iceland, Ireland, Israel, Italy, Japan, Luxembourg, the Netherlands, New Zealand, Norway, Portugal, Spain, Sweden, Switzerland, United Kingdom, and the United States of America.
} 
estimated, and the results are compared. To test whether the tendency towards convergence is considerably stronger when the basis for constructing groups is trade rather than proximity or common language, the countries are regrouped to reflect geographical closeness or common languages; and the degree of convergence within each of these groups are then compared to the results of the trade-based groups.

The results show that significant income convergence is not a common outcome among countries when they are grouped randomly instead of grouping them according to their trade partners; the convergence within groups is not towards one country that is common to most of the groups, but is instead an outcome that tends to be relatively robust to the exclusion of the major trade partners that are members in most of the groups; and the tendency towards convergence appears to be considerably stronger when the basis for constructing groups is trade rather than proximity or common language.

Chapter 4 provides recent evidence on determinants of the bilateral intra-industry trade in a multi-country \& multi-industry framework. Bilateral trade data of the year 2002 at three-digit SITC (Standard International Trade Classification) industry groups is used for 24 developed countries, namely Australia, Austria, Belgium, Canada, Denmark, Finland, France, Germany, Greece, Iceland, Ireland, Israel, Italy, Japan, Luxembourg, the Netherlands, New Zealand, Norway, Portugal, Spain, Sweden, Switzerland, United Kingdom, and USA.

First, a theoretical summary of a two-country model based on product differentiation and economies of scale is provided, following Helpman (1981) and Helpman and Krugman (1985). Then, using this model, the determinants of bilateral intra-industry trade are analyzed in the trade of each country with every other country in each industry category. The hypotheses that are tested 
in this study investigate the effect of the following country characteristics on the bilateral intraindustry trade: average country size, average per capita income, country size difference, per capita income difference, distance, common border, participation in economic integration systems, and common language.

Chapter 4 follows closely the studies of Helpman (1981), Helpman and Krugman (1985, ch.7), and Kim and Oh (2001). This research contributes to the existing literature of intra-industry trade in several ways. This study employs very recent trade data, namely data of 2002. Second, the data in the analysis is wide-ranging ${ }^{43} ; 24$ developed countries are included. Third, this study concentrates on testing country characteristics while most empirical studies ${ }^{44}$ of intra-industry trade have concentrated on testing industry characteristics such as economies of scale and product differentiation. Fourth, the empirical analysis covers a wide variety of country characteristics together, which are developed separately in the literature, i.e., average country size, average per capita income, country size difference, per capita income difference, distance, common border, participation in economic integration systems, and common language.

The empirical results show that the extent of intra-industry trade is positively correlated with average GNP, average GNP/capita, and the existence of a common border; and it is negatively correlated with differences in GNP and GNP/capita, and distance. All the variables are highly significant statistically. The EU and NAFTA dummy variables have the expected positive sign and are highly significant statistically. The regression coefficients of the language dummy

\footnotetext{
${ }^{43}$ The total number of observations is expected to be $12,144\left(={ }_{24} \mathrm{C}_{2}(=276)\right.$ country combinations $\mathrm{x} 44$ SITC categories) but in considerable amount of cases $(18 \%)$ neither exports nor imports exist in bilateral trade flows. Then the index of intra-industry trade is not defined and these observations are excluded from the analysis.

${ }^{44}$ Clark (1993), Lundberg (1992), Ray (1991), Hamilton and Kniest (1991), Marvel and Ray (1987), Balassa (1986), Greenaway and Milner (1984).
} 
variables have a positive sign, but their level of statistical significance varies. Moreover, the results show that the variables Average GNP and Difference in GNP are the country characteristics that contribute the most to the explanatory power of the regression equations. 